RENATO DE MELLO RUIZ

\title{
PAPEL DA PROTEINA HFQ NA REGULAÇÃO DOS FATORES DE VIRULÊNCIA DE Escherichia coli ENTEROPATOGÊNICA (EPEC)
}

Tese apresentada ao Programa de Pós-Graduação Interunidades em Biotecnologia USP/IPT/Instituto Butantan, para obtenção do Título de Doutor em Biotecnologia. 
RENATO DE MELLO RUIZ

\section{PAPEL DA PROTEINA HFQ NA REGULAÇÃO DOS FATORES DE VIRULÊNCIA DE Escherichia coli ENTEROPATOGÊNICA (EPEC)}
Tese apresentada ao Programa de Pós-Graduação Interunidades em Biotecnologia USP/IPT/Instituto Butantan, para obtenção do Título de Doutor em Biotecnologia.

Área de Concentração: Biotecnologa

Orientador: Dr. Marcelo Palma Sircili

Versão original 
DADOS DE CATALOGAÇÃO NA PUBLICAÇÃO (CIP)

Serviço de Biblioteca e Informação Biomédica do Instituto de Ciências Biomédicas da Universidade de São Paulo

reprodução não autorizada pelo autor

Ruiz, Renato de Mello.

Papel de Hfq na regulação dos fatores de virulência de Escherichia coli enteropatogênica / Renato de Mello Ruiz. -- São Paulo, 2014.

Orientador: Prof. Dr. Marcelo Palma Sircili.

Tese (Doutorado) - Universidade de São Paulo. Instituto de Ciências Biomédicas. Programa de Pós-Graduação Interunidades em Biotecnologia USP/IPT/Instituto Butantan. Área de concentração: Biotecnologia. Linha de pesquisa: Regulação gênica.

Versão do título para o inglês: Role of Hfq in the regulation of virulence factors in enteropathogenic Escherichia coli.

1. Escherichia coli 2. EPEC 3. Hfq 4. Regulação I. Sircili, Prof. Dr. Marcelo Palma II. Universidade de São Paulo. Instituto de Ciências Biomédicas. Programa de Pós-Graduação Interunidades em Biotecnologia USP/IPT/Instituto Butantan III. Título. 
Candidato(a): $\quad$ Renato de Mello Ruiz.

Título da Tese: $\quad$ Papel de Hfq na regulação dos fatores de virulência de Escherichia coli enteropatogênica.

Orientador(a): $\quad$ Prof. Dr. Marcelo Palma Sircili.

A Comissão Julgadora dos trabalhos de Defesa da Tese de Doutorado, em sessão pública realizada a ..................., considerou

\section{( ) Aprovado(a)}

( ) Reprovado(a)

Examinador(a): Assinatura: .

Nome:

Instituição:

Examinador(a): Assinatura:

Nome:

Instituição:

Examinador(a): Assinatura:

Nome:

Instituição:

Examinador(a): Assinatura:

Nome:

Instituição:

Presidente: Assinatura:

Nome:

Instituição: 


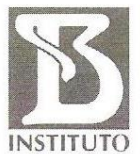

BUTANTAN
COMISSÃO DE ÉTICA NO USO DE ANIMAIS

INSTITUTO BUTANTAN (CEUAIB)

Av. Dr. Vital Brasil, 1500, CEP 05503-900, São Paulo, SP, Brasil

Telefone: (55) (011) 2627-9585 - Fax: (55) (011) 2627-9505

ceuaib@butantan.gov.br

São Paulo, 20 de junho de 2014

\section{CERTIFICADO}

Certificamos que o projeto "Papel de Hfq na regulação de fatores de virulência em amostras de Escherichia coli Enteropatogênica", protocolo n. I-1268/14, sob a responsabilidade de Marcelo Palma Sircili, não envolve a criação e/ou utilização de animais pertencentes ao filo Chordata, subfilo Vertebrata, para fins de pesquisa científica.

This is to certify that the proposal "Role of Hfq in the regulation of virulence factors in Enteropathogenic Escherichia coli", protocol n ${ }^{0} \mathrm{I}-1268 / 14$, under the responsibility of Marcelo Palma Sircili, has been reviewed by the Institute Butantan Animal Care and Use Committee, and that it does not involve breeding and/or use of animals belonging to phylum Chordata, subphylum Vertebrata, in scientific research.

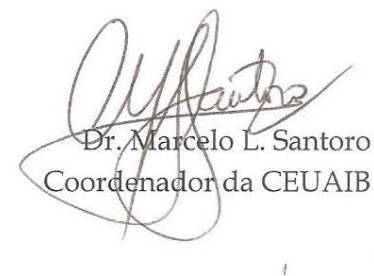


Este trabalho foi desenvolvido no Laboratório de Genética do Instituto Butantan (São Paulo, SP), com o auxílio financeiro do Conselho Nacional de Pesquisa e Desenvolvimento (Processo número 141758/2011-2) 
Aos meus pais, por todo amor e incentivo durante a minha vida; aos meus irmãos, pelo apoio incondicional. 


\section{AGRADECIMENTOS}

Agradeço ao Dr. Marcelo Palma Sircili, primeiramente pela amizade durante esses nove anos de Instituto Butantan. Segundo, pela confiança em mim depositada durante a execução deste projeto.

Agradeço aos amigos de bancada, Dra. Vanessa Bueris, Ms. Hebert Fabricio Culler, mestrandos Juliana Suyama Higa, Samuel Campanelli Freitas Couto e Min Jung Yang por toda ajuda durante este trabalho e amizade.

Aos pesquisadores e amigos do Laboratório de Genética, pela ajuda e amizade.

Aos funcionários do Laboratório de Genética do Instituto Butantan por toda a ajuda.

Aos amigos da Bacteriologia por toda ajuda sempre que requisitada.

À minha namorada Viviane, por este último ano, sempre me apoiando e sempre sorrindo para mim quando tudo parece o pior.

À minha familia e meus amigos por ser a estrutra, a base da minha vida.

E por último, mas não menos importante, à DEUS, por tudo isso citado acima... 
"Há homens que lutam um dia e são bons. Há utros que lutam un ano e sõa melhores. Há os que lutam muitos anos e são melhores. Porém, há os que lutam toda vida. Esses são imprescindíveis" 


\section{RESUMO}

RUIZ, R. M. Papel de Hfq na regulação dos fatores de virulência de Escherichia coli enteropatogênica (EPEC) 2014. 84 f. Tese (Doutorado em Biotecnologia) Instituto de Ciências Biomédicas, Universidade de São Paulo, São Paulo, 2014.

Amostras de Escherichia coli Enteropatogênica fazem parte de um importante grupo de patógenos capazes de causar diarréia. As EPEC podem ser classificadas em típica e atípica, com base na presença do plasmídeo EAF. As amostras de EPEC apresentam em seu genoma uma ilha de patogenicidade denominada região LEE, na qual estão contidos os genes relacionados à formação da lesão $(A / E)$. A regulação gênica da região LEE é multifatorial e um dos seus principais reguladores é o gene ler. Até o momento, não existem trabalhos analisando a participação de Hfq em EPEC. O presente estudo analisa o papel de Hfq na regulação dos fatores de virulência de EPEC típica (0127:H6) e atípica (O55:H7). A mutagênese do gene hfq foi obtida através do sistema $\lambda$ Red de recombinação alélica. As amostras mutantes apresentaram uma diminuição na capacidade de adesão e formar a lesão $\mathrm{A} / \mathrm{E}$. Analise transcricional dos mutantes revelou uma significativa diminuição na transcrição do gene espA e do gene eae. Foi possível evidenciar uma diminuição da motilidade das amostras mutantes. A análise in silico revelou a possibilidade do dobramento natural do mRNA ler, bloqueando o sítio de ligação do ribossomo. Aqui demonstramos a necessidade de Hfq para a transcrição dos genes responsáveis pela lesão $A / E$.

Palavras-chave: Escherichia coli. EPEC. Hfq. Regulação. 


\begin{abstract}
RUIZ, R. M. Role of $\mathrm{Hfq}$ in the regulation of virulence factors in Enteropathogenic Escherichia coli. 2014. 84 p. Ph. D. thesis (Biotechnology) Instituto de Ciências Biomédicas, Universidade de São Paulo, São Paulo, 2014.

Enteropathogenic Escherichia coli strains are part of an important group of pathogens responsible for causing diarrhea. EPEC can be classified as typical and atypical, based on the presence of the EAF plasmid. EPEC strains have in their genome a pathogenicity island known as LEE region, where it harbours genes related to the formation of a lesion $A / E$. LEE regulation is multifactorial, and ler gene is the main regulator. Until now there are no studies on the role of Hfq in EPEC, thus, the present study analyzes the function of $\mathrm{Hfq}$ on the regulation of virulence factors in typical EPEC (O127:H6) and atypical (O55:H7) strains. hfq gene mutagenesis was obtained utilizing the allelic recombination $\lambda$ Red system. The mutant strains demonstrated a decrease in the capability of adherence and formation of A/E lesion. Transcriptional analysis showed a decrease on the espA gene and eae gene transcription. It was possible to notice a decrease in motility of the mutant strains. In silico analysis revealed the possibility of a natural folding of ler mRNA, blocking the ribosome binding site. With this study we could demonstrate the need of Hfq for the transcription of genes responsible for the A/E lesion.
\end{abstract}

Keywords: Escherichia coli. EPEC. Hfq. Regulation. 


\section{LISTA DE FIGURAS}

Figura 1 - Microscopia da lesão A/E

Figura 2 - Representação esquemática da região LEE, indicando seus operons e promotores.

Figura 3 - Microscopia eletrônica de transmissão do flagelo.............................. 21

Figura 4 - Esquema representativo dos componentes do flagelo....................... 23

Figura 5 - Estrutura de Hfq (A), e interação de Hfq ao sRNA e ao mRNA, e consequentemente a formação do complexo regulatório.

Figura 6 - Esquema de atuação de Hfq.

Figura 7 - Esquema de recombinação............................................................... 30

Figura 8 - Mapa ilustrativo do plasmídeo pBADMycHis..

Figura 9 - Eletroforese em gel de agarose dos produtos da amplificação do gene $h f q$......

Figura 10 - Eletroforese em gel de agarose $1 \%$ do produto da amplificação do cassete de resistência cat.

Figura 11 - Eletroforese em gel de agarose dos produtos da amplificação do gene $h f q$.

Figura 12 - Análise do alinhamento gerado pelo programa Blast utilizando os iniciadores Hfq_Det_Fe Hfq_Det_R das amostras selvagens.

Figura 13 - Análise do alinhamento gerado pelo programa Blast utilizando os iniciadores Hfq_Det_Fe Hfq_Det_R das amostras mutantes.

Figura 14 - Eletroforese em gel de agarose dos produtos de amplificação utilizando iniciadores: Hfq_F/ R e Hfq_Det_F/ R

Figura 15 - Eletroforese em gel de agarose dos produtos de amplificação utilizando os iniciadores $\mathrm{Hfq} \_\mathrm{F} / \mathrm{R}$

Figura 16 - Curva de crescimeto das amostra O127:H6, O127:H6 hhfq::cat; e O127:H6 $4 h f q ; ; c a t$ (pBAD+hfq) em caldo TSB cultivado sob agitação constante de 300 rpm a $37^{\circ} \mathrm{C}$

Figura 17 - Curva de crescimeto das amostra O55:H7, O55:H7Ahfq::cat; e O55:H7Ahfq;;cat (pBAD+hfq) em caldo TSB cultivado sob agitação constante de 300 rpm a $37^{\circ} \mathrm{C}$

Figura 18 - Teste de adesão em células HEp-2 após 6h de interação bactérias-células epiteliais. 
Figura 19 - Teste de adesão em células HEp-2 após 6h de interação bactérias-células epiteliais

Figura 20 - Ensaio de formação da lesão A/E de 6 horas de interação das amostras com células HeLa

Figura 21 - Ensaio de formação da lesão A/E de 6 horas de interação das amostras com células HeLa.

Figura 22 - Eletroforese em gel de poliacrilamida com dodecil sulfato de sódio (12\%) dos extratos proteicos totais das amostras deste estudo.

Figura 23 - Eletroforese em gel de poliacrilamida com dodecil sulfato de sódio $(12 \%)$ dos extratos proteicos totais das amostras deste estudo.

Figura 24 - Reatividade do soro anti-espA contra as proteínas totais (A) e secretadas (B)

Figura 25 - Ensaio de motilidade em placas de Petri contendo 0,3\% de ágar bacteriológico, $1 \%$ de triptona e $0,25 \%$ de $\mathrm{NaCl}$, incubadas por 8 horas a 37 ${ }^{\circ} \mathrm{C}$.

Figura 26 - Ensaio de motilidade em placas de Petri contendo 0,3\% de ágar bacteriológico, $1 \%$ de triptona e $0,25 \%$ de $\mathrm{NaCl}$, incubadas por 8 horas a 37 ${ }^{\circ} \mathrm{C}$

Figura 27 - Analise da transcrição dos genes: ler (A), espA (B) e eae (C) por

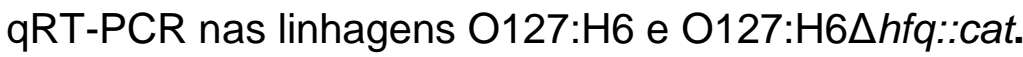

Figura 28 - Analise da transcrição dos genes: ler (A), espA (B) e eae (C) por qRT-PCR nas linhagens O55:H7 e O55:H7Ahfq::cat.

Figura 29 - Analise da transcrição do gene fliC por qRT-PCR nas linhagens O55:H7 e O55:H7 $h$ hq:::cat.

Figura 30 - Analise transcricional gerada a partir dos dados de qRT-PCR.........

Figura 31 - Eletroforese em gel de poliacrilamida 15\% em condição desnaturante.

Figura 32 - A análise in silico feita on line no RNAfold Web Server. 63

Figura 33 - Esquema proposto da regulação da região LEE. 


\section{LISTA DE TABELAS}

Tabela 1 - Amostras bacterianas e plasmídeos usadas nesse estudo................. 28

Tabela 1 - Amostras bacterianas e plasmídeos usadas nesse estudo................. 29

Tabela 3 - Sequência dos iniciadores utilizados nos ensaios de qRT-PCR.......... 37 


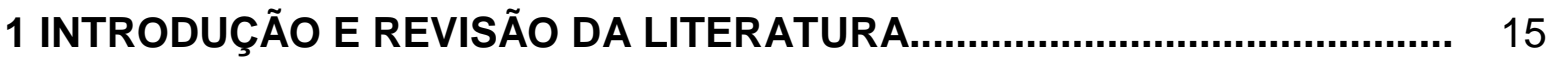

1.1 Escherichia coli Enteropatogênica..................................................... 15

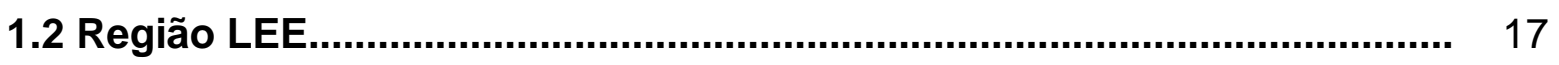

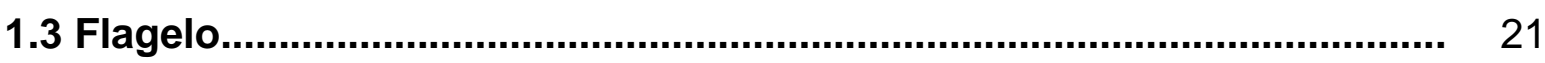

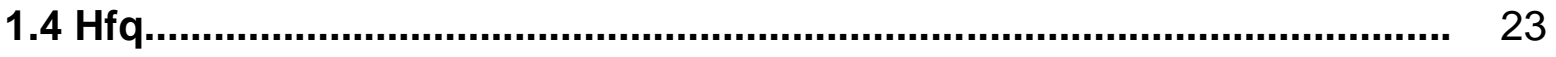

2 OBJETIVO

3 MATERIAL E MÉTODOS..................................................................... 28

3.1 Meios de cultura e soluções.............................................................. 28

3.2 Amostras bacterianas e plasmídeo...................................................... 28

3.3 Reações em cadeia da polimerase (PCR)............................................. 29

3.4 Eletroforese de DNA em gel de agarose............................................... 29

3.5 Mutagênese através do sistema $\lambda$ Red.................................................... 30

3.5.1 Extração de plasmídeo.................................................................... 30

3.5.2 Célula Eletrocompetente................................................................ 31

3.5.3 Transformação por Eletroporação........................................................ 31

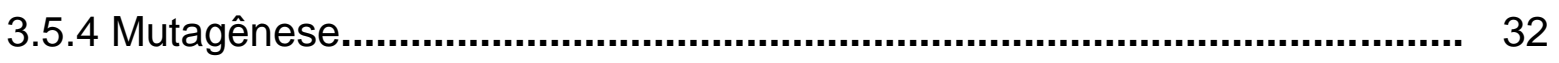

3.5.5 Confirmação dos mutantes..................................................................... 32

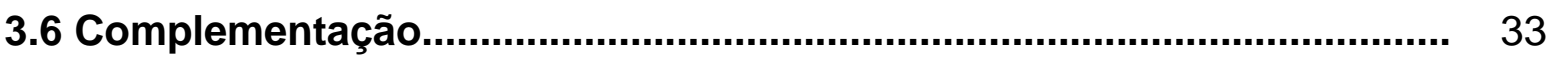

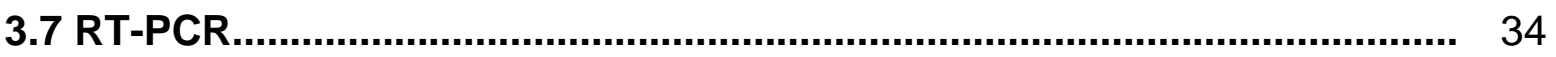

3.8 Curva de Cresecimento..................................................................... 34

3.9 Teste de adesão em células HeLa....................................................... 34

3.10 Teste de FAS ("Fluorescent actin staining") ........................................ 35

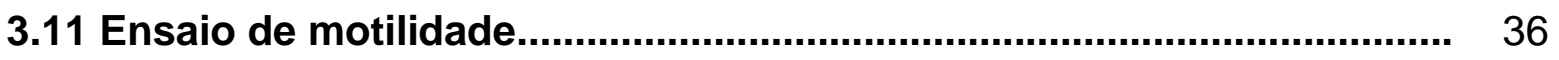

3.12 Eletroforese em gel de poliacrilamida com dodecil sulfato de

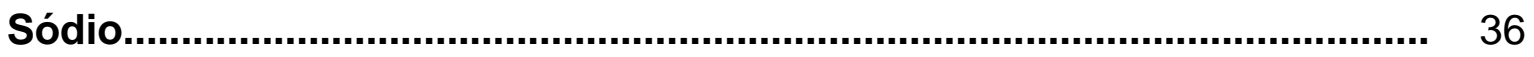

3.13 Western-blot e Imunodectecção........................................................ 36

3.14 PCR em Tempo Real.................................................................. 37

3.15 Extração de Small RNA...................................................................... 38

3.16 Analise in silico do RNA Mensageiro de ler......................................... 38 


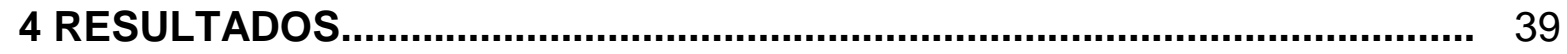

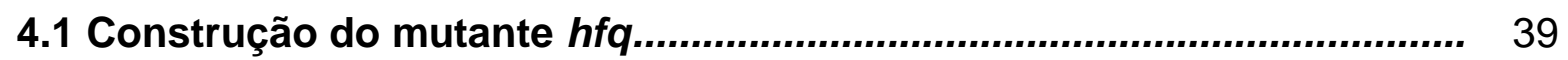

4.2 Analise transcricional do gene hfq....................................................... 44

4.3 Curva de Crescimento................................................................... 45

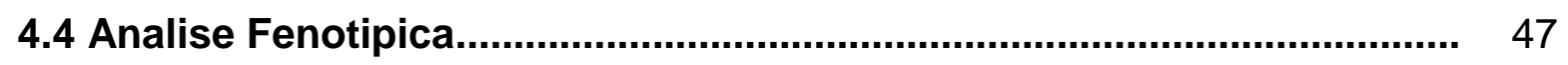

4.4.1 Teste de Adesão....................................................................................... 47

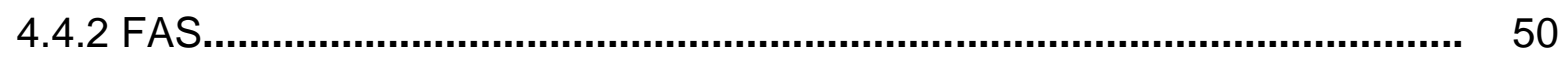

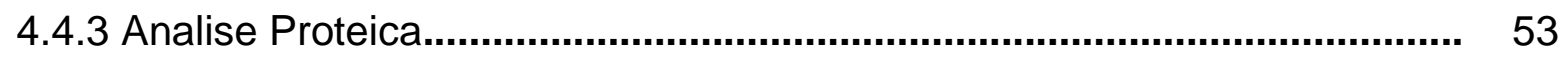

4.4.4 Analise da Proteína EspA................................................................. 54

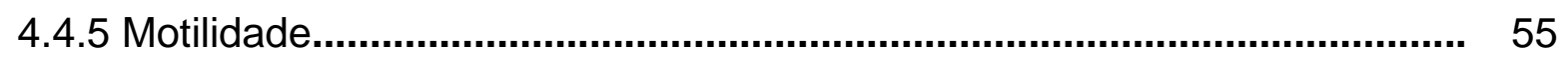

4.4.6 Analise Transcricional..................................................................... 57

4.5 Perfil de sRNA........................................................................... 62

4.6 Analise in silico do mRNA ler............................................................ 63

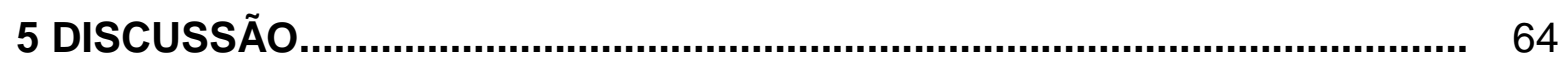

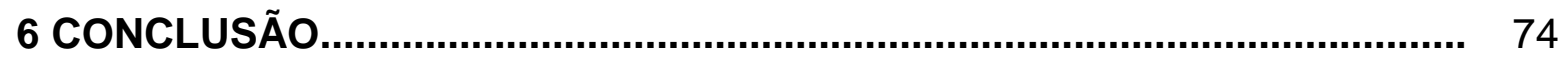

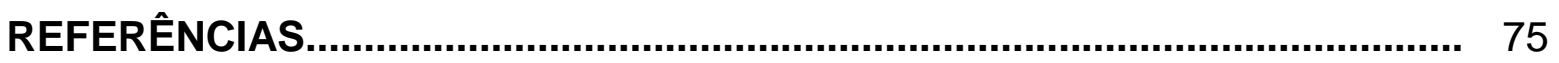




\section{INTRODUÇÃO}

As doenças bacterianas infecciosas estão entre as principais causas de morbidade e mortalidade (COHEN, 2000) e, dentre elas, destacam-se as infecções intestinais, responsáveis por cerca de 2 milhões de mortes por ano, principalmente entre crianças de países em desenvolvimento (O’RYAN et al., 2005). A Escherichia coli é o agente de uma grande proporção desses processos infecciosos, classificados como diarreia ou disenteria (CLARKE, 2001).

A Escherichia coli é uma bactéria facultativa da família Enterobacteriaceae, componente da microbiota intestinal humana e também responsável por importantes processos patológicos. Alguns clones específicos de E. coli são causadores de infecções intestinais e não fazem parte da microbiota intestinal residente. Essas amostras são denominadas E. coli diarreiogênicas ou DEC (NATARO; KAPER, 1998).

As amostras de DEC são de grande importância para a saúde pública e podem ser classificadas em seis patótipos ou categorias, considerando os seus mecanismos de virulência específicos, as síndromes clínicas causadas, os sorotipos $\mathrm{O}: \mathrm{H}$, os aspectos epidemiológicos e/ou os tipos de interação com linhagens celulares in vitro (NATARO; KAPER, 1998). Esses patótipos de DEC são: E. coli enteropatogênica (EPEC), E. coli enterotoxigênica (ETEC), E. coli enteroinvasora (EIEC), E. coli enterohemorrágica (EHEC), E. coli enteroagregativa (EAEC) e E. coli que adere difusamente às células epiteliais (DAEC) (NATARO; KAPER, 1998).

\subsection{Escherichia coli Enteropatogênica}

Escherichia coli Enteropatogênica foi descrita em 1955 por Neter durante um surto de diarréia no Reino Unido, sendo considerada uma importante categoria de DEC que tem sido associada a casos de diarreia em países desenvolvidos e em desenvolvimento (AFSET et al., 2004, TRABULSI; KELLER; GOMES, 2002). Em 1978, Levine realizou estudos com voluntários humanos utilizando a amostra 0127:H6 e demonstrou o potencial patogênico das EPEC. Baseado nesse estudo, a amostra O127:H6 (E2348/69) se tornou a amostra protótipo de EPEC (LEVINE et al., 1985; SCHMIDIT, 2010) 
O diagnóstico das EPEC pode ser realizado através de métodos sorológicos, com base na detecção de um dos antígenos $O$ definidos para essa categoria pela Organização Mundial da Saúde. São esses sorogrupos: O26, O55, O86, O111, O114, O119, O125, O126, O127, O128, 0142 e 0158 (TRABULSI et al., 1996; WHO, 1987). Entretanto, essa metodologia pode levar à detecção de outros patótipos de DEC, uma vez que alguns desses sorogrupos são constituídos por sorotipos O:H que correspondem a outros patótipos (TRABULSI; KELLER; GOMES, 2002). A deteç̧ão por métodos moleculares ou imunológicos dos genes de virulência ou dos seus produtos, que estão envolvidos no estabelecimento da lesão A/E, também pode ser empregada (KAPER; NATARO; MOBLEY, 2004).

As EPEC foram subdivididas nos grupos EPEC típica e atípica. O termo EPEC atípica foi sugerido durante o Simpósio Internacional de Escherichia coli Enteropatogênica, realizado na cidade de São Paulo em 1995, para denominar amostras de EPEC que possuem a região LEE (locus of enterocyte effacement) e que não transportam o plasmídeo EAF (KAPER, 1996).

Enquadra-se na definição de EPEC atípica uma vasta série de amostras de $E$. coli, que aparentemente emergiram recentemente e já estão entre os principais agentes de diarréia em nosso meio e em outros países (AFSET et al., 2003; BUERIS et al., 2007; COHEN et al., FRANZOLIN et al., 2005; 2005; SMITH et al., 1996; TRABULSI; KELLER; GOMES, 2002). Estudos epidemiológicos realizados nos últimos dez anos têm demonstrado uma sobreposição do número de EPEC atípicas em relação às EPEC típicas em números de casos (AFSET et al., 2003; AFSET et al., ARAUJO et al., 2007; 2004; BUERIS et al., 2007; FRANZOLIN et al., 2005; MORENO et al., 2008, SCALETSKY et al., 2009), posicionando as EPEC atípicas como patógenos emergentes.

As EPEC atípicas descritas em vários estudos epidemiológicos são muito heterogêneas em termos de sorotipos, padrões de adesão e fatores de virulência adicionais (AFSET et al., 2008; ARAUJO et al., 2007; DULGUER et al., 2003; GOMES et al., 2004; NGUYEN et al., 2006; ROBINS-BROWNE et al., 2004; SCALETSKY et al., 2002; VIEIRA et al., 2001), característica bastante distinta das EPEC típicas (TRABULSI; KELLER; GOMES, 2002).

Diversos estudos utilizando a amostra de EPEC atípica O55:H7 foram realizados nos últimos anos, o que levou a escolha desta amostra para este estudo (BUERIS et al., 2007; FRANZIN, 2013; ROCHA, 2010). 


\subsection{Regiao LEE}

As amostras de EPEC típica e atípica têm em comum a capacidade de causar a lesão histopatológica denominada lesão attaching and effacing (lesão $\mathrm{A} / \mathrm{E}$ ). Esta lesão é caracterizada pela destruição das microvilosidades intestinais, aderência íntima da bactéria à membrana apical da célula epitelial e formação de estruturas celulares semelhantes a pedestais (figura 1), sendo considerada responsável pela causa da diarreia (MOON et al., 1983). Além de EPEC, outros patógenos possuem a região LEE funcional como: E. coli Enterohemorrágica (EHEC) do sorotipo 0157:H7, que causa diarreia sanguinolenta e Síndrome Hemolítica Urêmica (HUS); Hafnia alvei, que causa diarreia em crianças; Citrobacter rodentium, patógeno de ratos; e REPEC ("Rabbit Enteropathogenic E. coli"), que causa diarreia em coelhos (MELLIES et al.,1999).

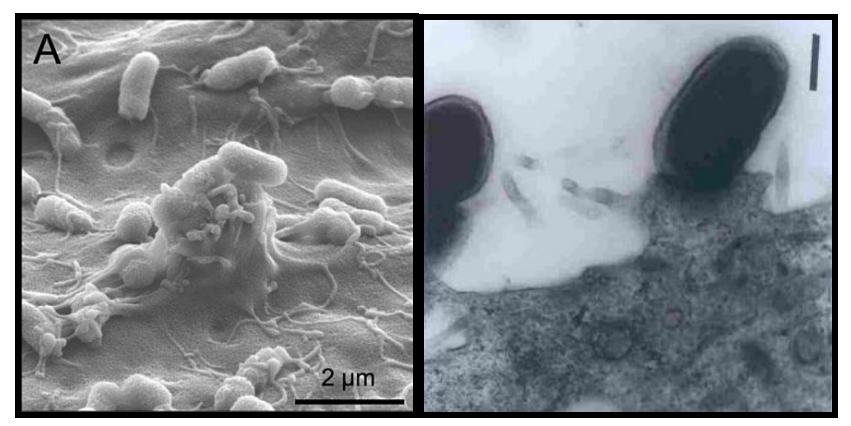

Figura 1 - Microscopia eletrônica de varredura da lesão A/E (SCHMIDT, 2010), microscopia eletrônica de transmissão da lesão A/E (BUERIS, 2008)

As proteínas envolvidas na formação da lesão $A / E$ são codificadas pelos genes presentes em uma ilha de patogenicidade de 35,6 kb, denominada região LEE (locus of enterocyte effacement) (CHEN; FRANKEL, 2005). Os genes que fazem parte da região LEE estão organizados em cinco operons de funções conhecidas: LEE 1, LEE 2, LEE 3, LEE 4 e LEE 5 (MELLIES et al., 1999; SANCHES-SANMARTIN et al., 2001).

A região LEE 5 contém os genes eae ( $E$. coli attaching and effacing), que codifica a adesina intimina que medeia a aderência intima da bactéria ao epitélio intestinal; tir (translocated intimin receptor), que codifica o receptor da intimina (Tir), o qual é translocado para a célula hospedeira através do sistema de secreção do tipo IIII e inserido na membrana da célula hospedeira; map (mitocondrial associated 
protein), que atua na membrana da mitocôndria causando uma disfunção no potencial de membrana; e cesT que é a chaperonina de Tir e Map (SANCHESSANMARTIN et al., 2001).

As regiões LEE 1, LEE 2 e LEE 3 contêm os genes que codificam as proteínas necessárias para o sistema de secreção do tipo III, chamadas Esc (EPEC secretion) e Sep (secretion of EPEC proteins), além do regulador ler (LEE-encoded regulator) (MELLIES et al., 1999a). As EPEC utilizam o sistema de secreção do tipo III para injetar proteínas efetoras na membrana plasmática e no citoplasma da célula hospedeira (HUECK, 1998). Um complexo protéico formado pelas EscD, R, S, T e U são responsáveis por formar um poro na membrana interna da bactéria; EscJ forma uma estrutura no espaço periplasmático conectando a membrana externa à membrana interna; EscF se projeta pela membrana externa, formando uma estrutura à qual EspA liga-se diretamente, formando um canal até a célula hospedeira; EscN está relacionada com a conversão da energia para a secreção (GAUTHIER; FINLAY, 2002). A maioria dos genes que codificam o sistema de secreção tipo III de E. coli tem homologia com os genes do aparato de secreção de Yersinia spp, Shigella spp e Salmonella spp (FRANKEL et al., 1998).

A região LEE 4 contém os genes que codificam as proteínas Esp (EPECsecreted proteins), que são produzidas durante o curso da infecção (NATARO; KAPER, 1998) e são secretadas pelo sistema de secreção do tipo III. EspA é uma proteína estrutural filamentosa de $25 \mathrm{kDa}$ localizada na superfície bacteriana, que interage com o epitélio celular nos primeiros estágios da lesão $A / E$, formando um canal para translocação de efetores para a célula hospedeira (FRANKEL et al., 1998). EspB (38 kDa) e EspD (40 kDa) formam um complexo poroso no epitélio celular através do qual as proteínas serão translocadas (MAIRENA et al., 2003). EspF, que é secretada para o interior da célula hospedeira, atua na destruição das junções oclusivas do epitélio intestinal (McNAMARA, et al., 2001). Essas proteínas podem ser separadas em dois grupos funcionais: efetores translocados (Tir, EspF, EspG) e componentes do aparato de translocação (EspA, EspB, EspD).

Recentemente, Yerushalmi et al. (2014) descreveram que a região LEE possui 12 regiões intergênicas e que cada região contém seu próprio promotor. Essas regiões foram, então, classificadas da seguinte forma: LEE6 (espG e rorf1), LEE1, rorf3, LEE7 (operon grlA), LEE2, LEE3, cesF, map, LEE5, cesT, escD e 
LEE4. A figura 2 mostra o esquema representativo da região LEE com seus promotores.

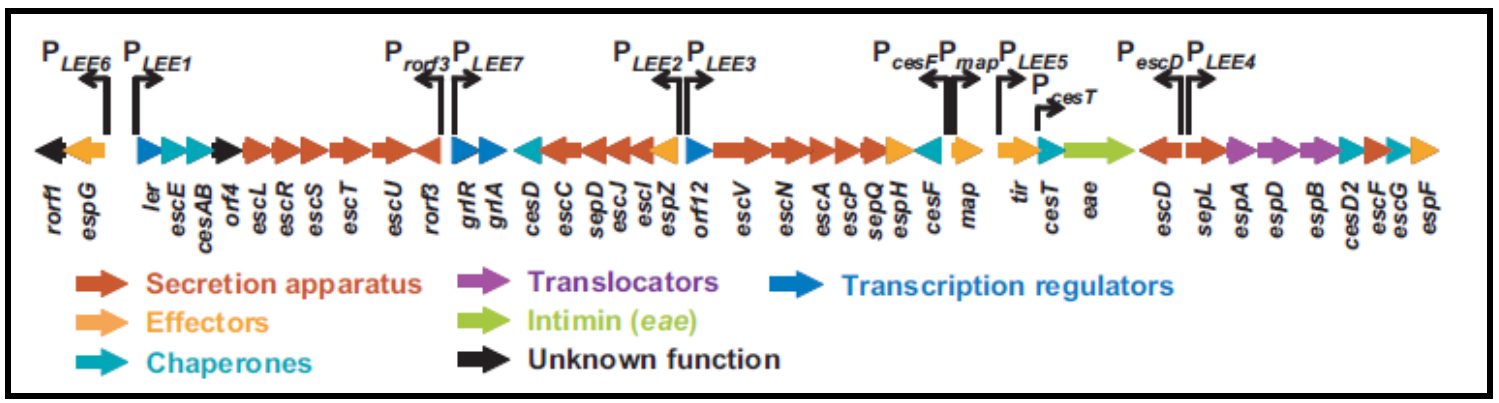

Figura 2 - Representação esquemática da região LEE, indicando seus operons e promotores (YERUSHALMI et al., 2014)

A proteína Ler (LEE Encoded Regulator), codificada pelo gene ler presente na região LEE1, é considerada o principal regulador da região LEE. É uma proteína da família H-NS de 15 kDa, que contém em sua região carboxi um domínio de ligação ao DNA. Os reguladores globais H-NS reprimem a expressão dos genes LEE e Ler atua na expressão dos mesmos, competindo pela disponibilidade dos promotores (BARBA et al., 2005; WINARDHI et al., 2014).

Os genes grlAR tem papel importante na regulação de ler e estão inseridos na região LEE, no operon recentemente denominado LEE7 (YERUSHALMI et al., 2014). Esses genes atuam de maneira positiva sobre ler através de GrlA (Gobal Regulator LEE Activator), e negativamente através de GrlR (Gobal Regulator LEE Repressor). GrlA e GrlR são co-expressos e GrlR atua inibindo GrlA (BARBA et al., 2005; BUSTAMANTE et al., 2011; PADAVANNIL et al., 2013).

Além da região LEE, as EPEC típicas apresentam um plasmídeo denominado EPEC adherence factor (EAF), cujo tamanho varia entre 50 a $70 \mathrm{MDa}$ (BALDINI et al., 1983), e que contém os genes envolvidos com a biogênese da fimbria bundleforming pilus (BFP) e do operon plasmid encoded regulator (per), o qual codifica um complexo regulador dos genes de virulência de EPEC (TRABULSI; KELLER; GOMES, 2002).

A adesina BFP é uma fímbria do tipo IV organizada na forma de feixes, relacionada à adesão localizada das EPEC à célula hospedeira (GIRÓN et al., 
1991), que participa da formação de microcolônias bacterianas em pontos específicos da superfície celular in vitro e in vivo (KNUTTON et al., 1987; SCALETSKY et al., 1984).

O complexo regulador PerABC, homólogo da família AraC de ativadores transcricionais, ativa a transcrição do operon bfp e da região LEE, através da ativação de LEE1 (MELLIES et al., 1999). Sua importância é discutida, devido sua ausência em amostras de EHEC, EPEC atípica e Citrobacter rodentium, que são capazes de formar a lesão A/E (BUSTAMANTE et al., 2011). Entretanto, foi demonstrado que amostras de EPEC atípica complementadas com perABC, estabelecem a lesão A/E mais rapidamente (BUERIS, 2008).

O mecanismo de quorum sensing também está envolvido na regulação da região LEE de EPEC típica e atípica. Quorum sensing é um processo de sinalização celular baseado na produção e detecção de moléculas denominadas autoindutores $(\mathrm{Al})$, capazes de sincronizar a expressão de genes relacionados à virulência e à resistência a antibióticos (LENZ et al., 2005; NOVAK et al., 2010; SPERANDIO; TORRES; KAPER, 2002a). Em EHEC, quorum sensing está relacionado com a formação da lesão $A / E$, produção da toxina Stx, crescimento celular, produção do flagelo e motilidade (SPERANDIO; TORRES; KAPER, 2002). Recentes estudos descreveram a existência de sistemas de dois componentes relacionados ao quorum sensing; Al-1/luxIR, luxS/AI-2 e Al-3/adrenalina/noradrenalina, sendo que, até 0 momento, os sistemas Al-1 e Al-3 foram descritos em bactérias Gram-negativas, e Al-2 foi encontrado em ambas (PARKER; SPERANDIO, 2009).

As acil homoserina lactonas sintetizadas por luxl são secretadas para o meio extracelular e reconhecidas por luxR, que ativa a transcrição gênica (PARKER; SPERANDIO, 2009). Al-2 é secretado para o meio extracelular e seu reconhecimento pode ocorrer através de 2 vias, LsrR e LuxQ, que ativam LsrK e LuxO respectivamente, disparando uma cascata de sinalização que envolve genes relacionados com a síntese, captura e catabolismo de aminoácidos para a geração de piruvato e succinato, e fatores de virulência (BACA-DELANCEY et al., 1999; WALTER; SPERANDIO, 2006). O sistema Al-3, além de reconhecer moléculas secretadas pelas próprias bactérias, é capaz de reconhecer e desencadear a transcrição de genes através de moléculas secretadas pelas células hospedeiras, como adrenalina e noradrenalina. Essas moléculas são reconhecidas pelo sistema de dois componentes QseBC. O gene qseC codifica um sensor histidina quinase 
responsável por ativar a transcrição do regulador $q s e B$, cujo produto está envolvido na ativação do flagelo e da motilidade (CLARKE et al., 2006; SPERANDIO; TORRES; KAPER, 2002a).

As EPEC típicas e atípicas também diferem com relação ao padrão de adesão em células epiteliais in vitro. As EPEC típicas apresentam o padrão de adesão localizada $(A L)$, caracterizado pela adesão bacteriana em pontos localizados da célula formando grupos compactos (SCALETSKY et al., 1984). As EPEC atípicas podem aderir ou não às células HEp-2. As amostras aderentes expressam predominantemente o padrão localizado-like (AL-L), caracterizado pela adesão bacteriana em pontos isolados da célula epitelial formando microcolônias frouxas (PELAYO et al., 1999; RODRIGUES et al., 1996; SCALETSKY et al., 1999), podem também apresentar o padrão agregativo e difuso (ABE et al., 2009).

\subsection{Flagelo}

A colonização bacteriana é um processo multifatorial que envolve diversas adesinas. O flagelo contribui não só com a motilidade, mas também na formação de biofilme, ligação à proteínas do hospedeiro, aderência, invasão e colonização (ERDEM et al., 2007).

Amostras de E. coli possuem flagelo peritríquio que podem ser classificados em diferentes tipos $\mathrm{H}$, com base na variabilidade do domínio antigênico de FliC (HAIKO; WESTERLUND-WIKSTRÖM, 2013).

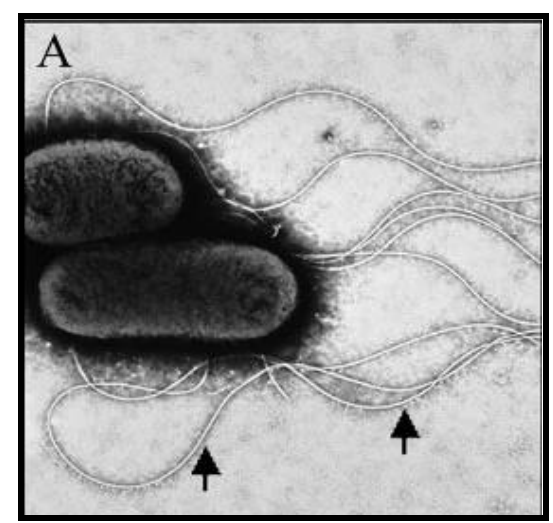

Figura 3 - Microscopia eletrônica de transmissão do flagelo (ERDEM et al., 2007) 
A síntese flagelar é um sistema complexo que envolve mais de 60 genes localizados em diversos operons, responsáveis pela motilidade e quimiotaxia. A regulação destes genes ocorre em níveis transcricionais e pós transcricionais (LAY; GOTTESMAN, 2012). Na base da hierarquia flagelar está o operon flhDC. FlhD e FlhC são proteinas regulatórias necessárias para a transcrição dos demais operons flagelares, participando da regulação do fator sigma flagelar ( $\sigma^{28}$ ou FliA). Mutantes em fIhDC perderam a atividade do fator transcricional $\sigma^{28}$ (ARNOSTI, 1990; LIU; MATSUMURA, 1994).

A formação do flagelo se dá através de uma estrutura semelhante ao anel nas membranas interna e externa do sistema de secreção do tipo III, formado por 26 cópias da proteina FliF. A haste próxima ao anel é formada por subunidades de FlgB, FlgC e FlgF e a região distal formada por 26 subunidades de FlgG. A proteína FliE é necessária para a eficiente secreção dessas subunidades. As proteínas integradas MotA e MotB formam o complexo necessário para a rotação do flagelo. A rotação do motor pode ter seu sentido alterado (horário ou anti-horário) através da fosforilação do sistema quimiosensor (CheY) e da participação de três proteínas: FliG, FliN e FliM. FliG está diretamente relacionada com a rotação do motor e interage com MotA e FliF (anel transmembrânico); FliM tem importante papel na troca do sentido da rotação por se ligar em CheY fosfatado; e FliN desempenha um papel na rotação e motilidade do tipo switching, além disso, parece contribuir para a exportação de energia após sua interação com a proteína ATPase FliH. O gancho é formado por cerca de 120 cópias de FlgE e o seu tamanho é controlado pelas proteínas FlhB e FliK. O filamento flagelar é constitutido por cerca de 20.000 subunidades, formando um tubo oco, constituído por uma única proteina, a flagelina FliC. A ponta do flagelo é recoberta por 5 moléculas de FliD, em forma de uma estrutura anelar pentamérica, constituindo o cap flagelar (CHEVANCE; HUGHES, 2008; CHILCOTT; HUGHES, 2000). 


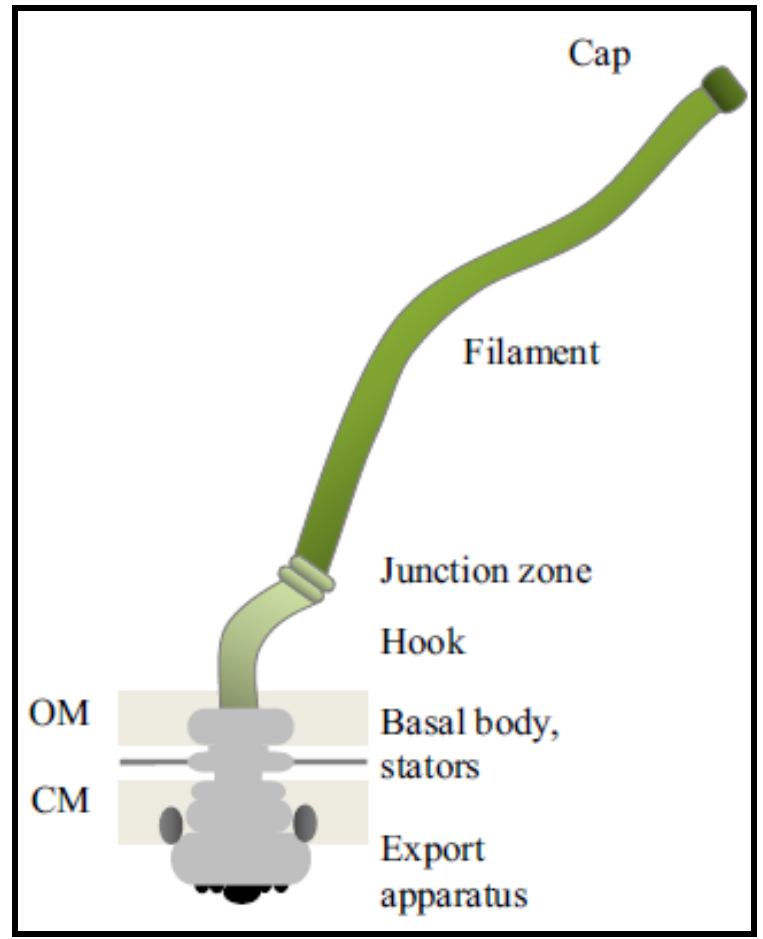

Figura 4 - Esquema representativo dos componentes do flagelo (HAIKO; WESTERLUNDWIKSTRÖM, 2013)

A participação do flagelo na patogenicidade, incluindo os processos de adesão, invasão e respota pró-inflamatória, tem sido relatada em diversos patógenos como: Salmonela enterica serovar Typhimurium (GEWIRTZ et al., 2001), Vibrio cholerae (CORREA et al., 2000) e Proteus mirabilis (MOBLEY et al., 1996). Em amostras de EPEC do sorotipo O127:H6, o flagelo participa do processo de adesão. Mutantes em fliC foram deficientes na adesão e amostras deletadas em genes do sistema de secreção do tipo III (escN, espA, espB e escN) e no regulador perA apresentaram a adesão mediada pelo flagelo (GIRÓN et al., 2002). Erdem et al. (2007) demonstraram a capacidade de falgelinas do sorotipo H6 e H7 se ligarem a componentes de matriz extracelular. Amostras de STEC do sorotipo O113:H21 mutantes em fliC, apresentaram redução da invasão (HAIKO; WESTERLUNDWIKSTRÖM, 2013)

\subsection{HFQ}

Hfq é uma proteína 11 kDa que tem participação na regulação gênica, foi primeiramente descrita como fator para a transcrição do fago $Q \beta$ e a sua ausência 
acarreta em diversos impactos nos processos celulares, tais como: redução do crescimento, resposta ao estresse, diminuição da virulência e quorum sensing (CHIANG et al., 2011; MØLLER et al., 2002). Esse papel desempenhado por Hfq na regulação pós transcricional está relacionado ao pareamento imperfeito de moléculas de small RNA (sRNA - pequenos fragmentos de RNA não codificadores) ao RNA mensageiro (mRNA) alvo (CHIANG et al., 2011; FRÖHLICH; VÖGEL, 2009; MØLLER et al., 2002; VÖGEL; LUISI, 2011). Estima-se que micro-organismos como a Salmonela sp e Escherichia coli possuam aproximadamente 100 diferentes sRNAs, com tamanhos que podem variar entre 50 a 400 nucleotídeos (FRÖHLICH; VOGEL, 2009; VOGEL; LUISI, 2011).

Os sRNAs podem atuar de duas maneiras: em cis, quando o sRNA encontrase na fita oposta ao mRNA que será regulado; e em trans, quando o sRNA encontrase em um loci diferente do mRNA regulado. A maioria dos sRNAs que atuam em trans necessitam da associação à proteína Hfq (SALIM et al., 2012; WAGNER, 2013).

Hfq é um hexâmero cuja porção proximal possui afinidade a regiões ricas em Adenina e Uracila e se liga ao sRNA; a porção distal se liga a regiões ricas em Adenina, como o mRNA (FANER; FEIG, 2013).

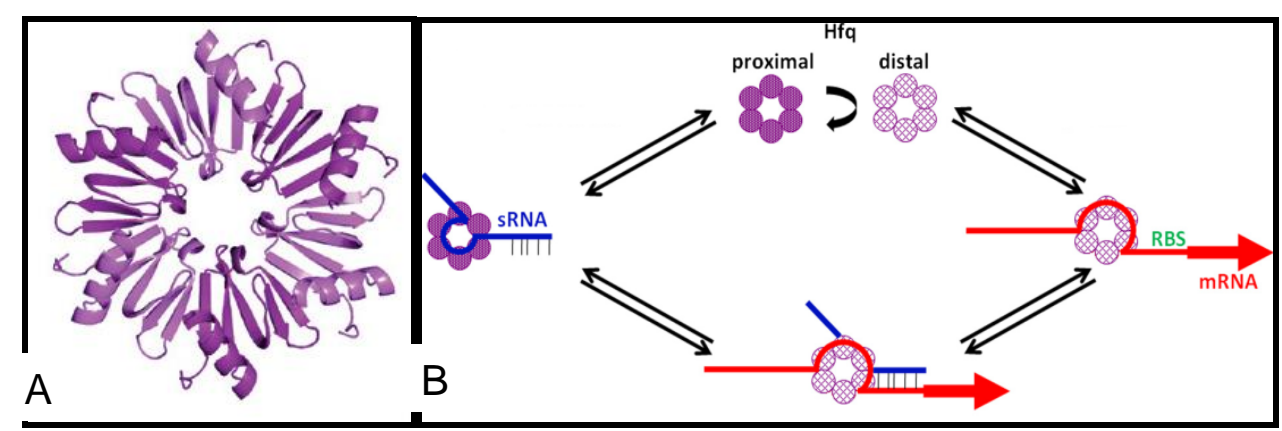

Figura 5 - Estrutura de Hfq (A) (VOGEL; LUISI, 2011), e interação de Hfq ao sRNA e ao mRNA, e consequentemente a formação do complexo regulatório (FANER; FEIG, 2013).

Estima-se que o número de hexâmeros por célula varia de 400 a 10.000. O motivo desta variabilidade permanece desconhecido. A disponibilidade de Hfq pode ser um fator limitante para a regulação por sRNAs e, em certas circustâncias, 0 sRNA e o mRNA podem competir por Hfq (HUSSEIN; LIM, 2011).

As formas de atuação da proteína Hfq associada ao sRNA são: liberação ou bloqueio do sítio de ligação do ribossomo (RBS), proteção dos sRNAs da ação da RNAseE e degradação do mRNA pela RNAseE. Hfq ainda pode estar associado ao 
mRNA levando à formação de uma cauda poli A pela PAP (Polimerase Poli A) e a subsequente degradação por uma Exonuclease (VOGEL; LUISI, 2011).

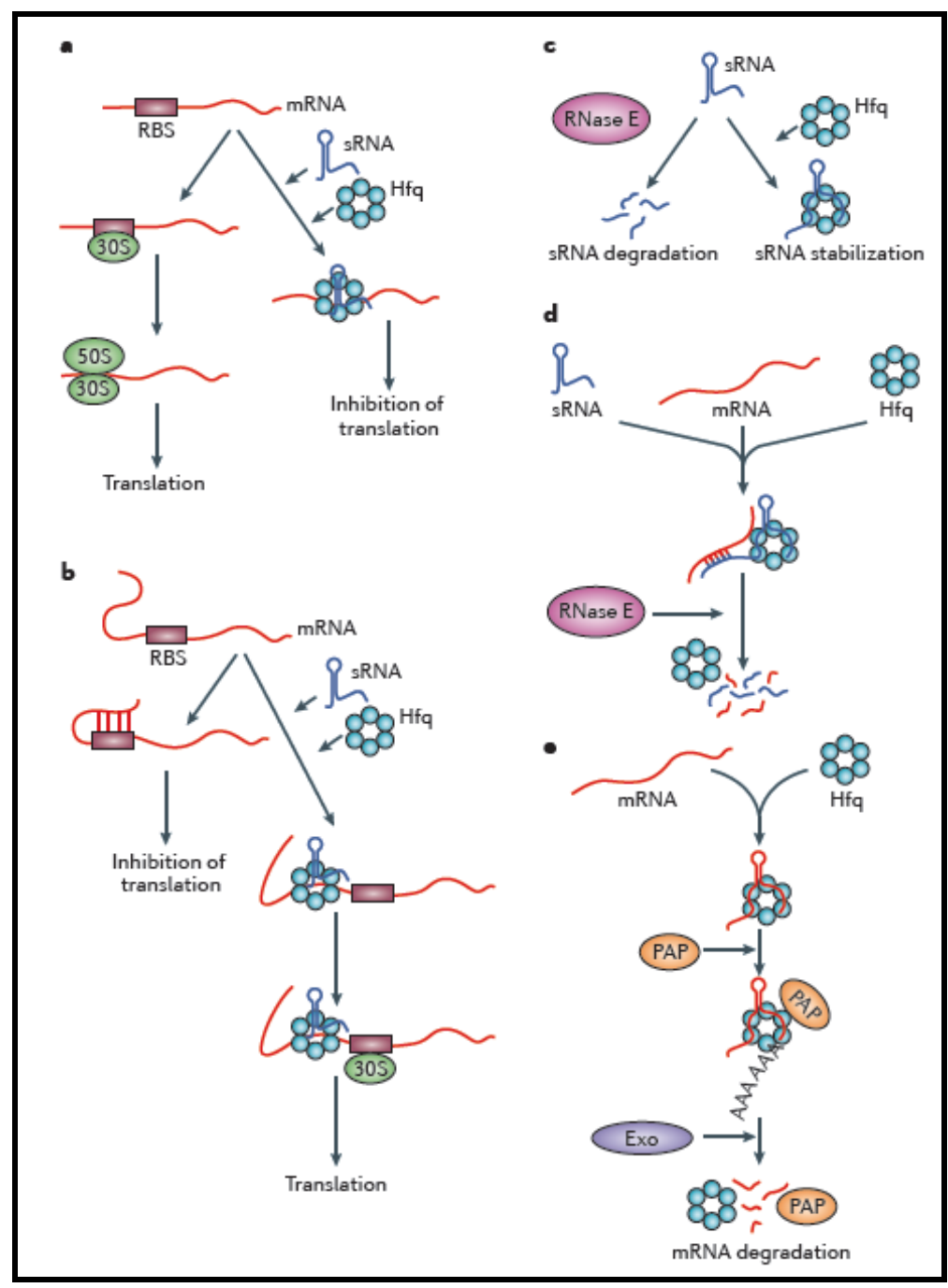

Figura 6 - Esquema de atuação de Hfq (VOGEL; LUISI, 2011)

Diversos processos são regulados por sRNAs. RpoS é o fator sigma $\left(\sigma^{\mathrm{s}}\right)$ associado ao estresse, expresso durante a fase estacionária e que serve como modelo de regulação por sRNA. Estudos têm demonstrado que, direta ou indiretamente, o fator sigma $\sigma^{\mathrm{s}}$ regula $10 \%$ dos genes de E. coli. Em baixas temperaturas, o sRNA DsrA junto com a chaperona Hfq, se liga ao mRNA de rpoS, impedindo o bloqueio do RBS, favorecendo a tradução (GOTTESMAN, 2004; SOPER; DOXZEN; WOODSON, 2011; VECEREK et al., 2010a). O sRNA OxyS se liga ao mRNA de rpoS bloqueando sua tradução (GOTTESMAN, 2004). 
A regulação do quorum sensing por sRNA está bem estabelecida com relação à Vibrio cholerae e Vibrio harveyi. A proteína Hfq juntamente com o sRNA, forma um complexo denominado Qrr (quorum sensing regulatory $R N A$ ). Em baixa densidade, e consequentemente com pouca disponibilidade de $\mathrm{Al}$, LuxO é fosoforilado e ativa a transcrição de 5 Qrr. Os Qrr ativam a tradução do regulador global AphA, que controla aproximadamente 300 genes relacionados à baixa densidade bacteriana (fase Lag). Na presença de maior concentração de Al, LuxO não é fosoforilado e, consequentemente não ocorre a transcrição de Qrr. Esse fenômeno ocasiona a tradução de LuxR, que regula a transcrição de aproximadamente 700 genes relacionados à alta densidade bacteriana (fase Log) ( BASSLER, 2012; LENZ et al., 2004, 2005; SHAO; TU; BASSLER, 2007).

Recentes estudos associando $\mathrm{Hfq}$ e quorum sensing em amostras de Escherichia coli Enterohemorrágica (EHEC) foram realizados. Na amostra protótipo EDL 933, a regulação da ilha de patogenicidade LEE (locus of enterocyte effacement) ocorre de forma negativa, sugerindo que Hfq e possivelmente sRNAs atuam no bloqueio do RBS com participação dos reguladores Ler e GrlA (HANSEN; KAPER, 2009; SHAKHNOVICH; DAVIS; WALDOR, 2009). Entretanto, em outra amostra protótipo de EHEC (86-24), a regulação de LEE por Hfq é positiva, assim como de QseBC. A toxina $\mathrm{Stx}_{2}$, por sua vez, é regulada negativamente (KENDALL et al., 2011). A participação de $\mathrm{Hfq}$, bem como de sRNAs em Escherichia coli Enteropatogênica (EPEC) ainda permanece desconhecida. 


\section{OBJETIVO}

Este trabalho teve como objetivo avaliar a participação de Hfq na regulação dos fatores de virulência de amostras de Escherichia coli Enteropatogênica típica e atípica.

Os objetivos específicos foram:

- Construção do mutante em Hfq das amostras 0127:H6 (EPEC típica) e 055:H7 (EPEC atípica);

- Avaliação do papel de Hfq na regulação gênica da região LEE;

- Avaliação do papel de Hfq na regulação gênica do flagelo. 


\section{MATERIAL E MÉTODOS}

\subsection{Meios de Cultura e Soluções}

Os meios de cultura utilizados para o cultivo e manutenção das amostras bacterianas, assim como as soluções empregadas nas diversas técnicas descritas a seguir, foram preparados de acordo com Sambrook et al. (1989).

\subsection{Amostras Bacterianas e plasmídeos}

As amostras bacterianas e os plasmídeos utilizados neste estudo estão listados na tabela 1. As amostras de Escherichia coli enteropatogênica típica e atípica (E2348/69 e O55:H7, respectivamente) fazem parte da coleção do Laboratório de Genética do Instituto Butantan.

Tabela 1. Amostras bacterianas e plasmídeos utilizados nesse estudo

\begin{tabular}{|c|c|c|}
\hline $\begin{array}{l}\text { Amostra ou } \\
\text { plasmídeo }\end{array}$ & Genótipo ou descrição & Referência ou fonte \\
\hline \multicolumn{3}{|l|}{ Amostra } \\
\hline E2348/69 & Amostra selvagem do sorotipo $\mathrm{O} 127: \mathrm{H} 6$ & Levine et al., 1985 \\
\hline RR01 & Mutante E2348/69 $\Delta h f q:: c a t$ & Este estudo \\
\hline RR02 & 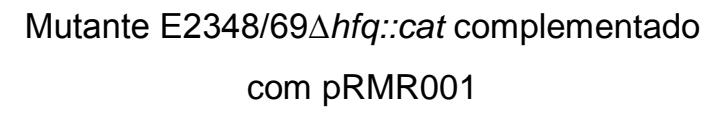 & Este estudo \\
\hline 320 & Amostra selvagem do sorotipo $\mathrm{O} 55: \mathrm{H} 7$ & Bueris et al., 2007 \\
\hline RR03 & Mutante $320 \Delta h f q:: c a t$ & Este estudo \\
\hline RR04 & $\begin{array}{c}\text { Mutante } 320 \Delta h f q:: \text { cat complementado com o } \\
\text { pRMR001 }\end{array}$ & Este estudo \\
\hline BW 25115 & $\begin{array}{c}\text { Amostra de E. coli K12 albergando o } \\
\text { plasmídeo pKD46 }\end{array}$ & $\begin{array}{l}\text { Datsenko e Wanner, } \\
2000\end{array}$ \\
\hline \multicolumn{3}{|l|}{ Plasmideos } \\
\hline pKD46 & $\begin{array}{l}\text { Plasmídeo auxiliar contendo os genes das } \\
\text { enzimas de recombinação (Sistema } \lambda \text { Red) }\end{array}$ & $\begin{array}{l}\text { Datsenko e Wanner, } \\
2000\end{array}$ \\
\hline pKD3 & $\begin{array}{l}\text { Molde para amplificação do cassete de } \\
\text { recombinação (Sistema } \lambda \text { Red) }\end{array}$ & $\begin{array}{l}\text { Datsenko e Wanner, } \\
2000\end{array}$ \\
\hline pBADMycHisA & Vetor de expressão comercial & Invitrogen, EUA \\
\hline pRMR001 & hfq no pBADMycHisA (complementação) & Este estudo \\
\hline
\end{tabular}




\subsection{Reações em Cadeia da Polimerase (PCR)}

Foram confeccionados pares de iniciadores para detectar a presença do gene hfq e para a obtenção das amostras mutantes nesse gene, com base na sequência das amostras E2348/69 e EDL933 depositadas no banco de dados GenBank (Número de acesso: NC_011601.1 e NC_002655.2, respectivamente). As sequências dos iniciadores estâo apresentadas na tabela 2. Para cada reação de PCR foram utilizados $25 \mathrm{pmol}$ de cada um dos iniciadores, $1 \mathrm{U}$ de Taq DNAPolimerase (Invitrogen, EUA), 1,5 mM de cloreto de magnésio, $200 \mu \mathrm{M}$ da mistura de dNTPs (dATP, dCTP, dGTP e dTTP), $5 \mu$ do tampão de reação de PCR 10x concentrado (Invitrogen, EUA) e água deionizada estéril para um volume final de 50 $\mu \mathrm{l}$.

Tabela 2. Sequência dos iniciadores utilizados nos ensaios de PCR

\begin{tabular}{lcc}
\hline Primer & Sequencia (5') $\mathbf{3}$ ') & Referencia \\
\hline Hfq_F & ATGGCTAAGGGGCAATCT & Este estudo \\
Hfq_R & TTATTCGGTTTCTTCGCTGTC & Este estudo \\
HfqMut_F & AAAGGTTCAAAGTACAAATAAGCATATAAGGAAAAGAGAGAGTGTAG & Este estudo \\
& GCTGGAGCTGCTTC & \\
HfqMut_R & GGATCGCTGGCTCCCCGTGTAAAAAACAGCCCGAAACCCATAT & Este estudo \\
Hfq_Det_F & GAATATCCTCCTTAGTTC & \\
Hfq_Det_R & ATGGTTTATCGAGGTGTTTGC & Este estudo \\
HfqXho & CTACAAAATACTTTGGGTGCG & Este estudo \\
HfqEco & GTCGCTCGAGAATGGCTAAGGGGCAATCT & Este estudo \\
\hline
\end{tabular}

\subsection{Eletroforese de DNA em gel de agarose}

Os géis foram preparados por aquecimento, fundindo-se agarose (Invitrogen, EUA) em tampão TAE 1 X (40 mM Tris-acetato, 2 mM EDTA), na concentração final de $1 \%$. Os fragmentos de DNA resultantes das PCRs foram acrescidos de tampão de amostra 1 X (azul de bromofenol 0,25\%, xileno cianol 0,25\%, glicerol $30 \%$ ). Como marcador de peso molecular foi utilizado o $1 \mathrm{~kb}$ Plus DNA Ladder (Invitrogen, 
EUA). Após a corrida eletroforética, realizada sob corrente constante de $90 \mathrm{~V}$ em tampão TAE $1 \mathrm{X}$, os géis foram corados em solução de brometo de etídio na concentração de $10 \mu \mathrm{g} / \mathrm{mL}$ durante 10 a $20 \mathrm{~min}$, e observados em transiluminador de luz ultravioleta.

\subsection{Mutagênese através do sistema $\lambda$ Red}

Os mutantes foram obtidos através do sistema $\lambda$ Red, conforme descrito por Datsenko e Wanner (2000). Essa metodologia consiste na substituição de uma sequência cromossomal por um gene de resistência a antibiótico, nesse caso cloranfenicol (figura 7). As etapas do processo serão detalhadas a seguir.

Step 1. PCR amplify FRT-flanked resistance gene

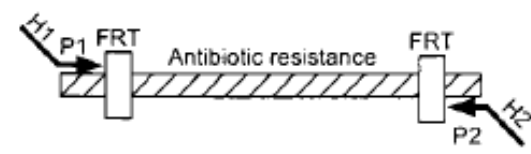

Step 2. Transform strain expressing $\lambda$. Red recombinase

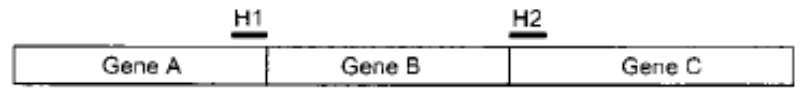

Step 3. Select antibiotic-resistant transformants

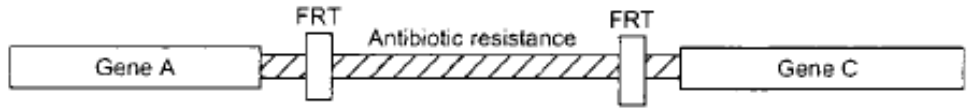

Figura 7 - Esquema de recombinação (Datsenko; Wanner, 2000)

\subsubsection{Extração plasmidial}

Inicialmente, as amostras foram transformadas com o plasmídeo pKD46 por eletroporação, seguindo protocolo descrito em Ausubel et al. (1995). O plasmídio pKD46 possui os genes $\gamma, \beta$ e exo que codificam respectivamente Gam, Bet e Exo. Gam inibe o sistema ExoV do hospedeiro, enquanto Bet e Exo promovem a recombinação de fragmentos lineares no DNA alvo (Datsenko e Wanner, 2000). Para isso, $10 \mathrm{ml}$ da cultura da amostra BW 25115 foram utilizados para a extração 
por lise alcalina através do kit PureYield Plasmid Miniprep System (Promega, EUA), seguindo recomendações do fabricante.

\subsubsection{Célula Eletrocompetente}

Para a transformação, as células eletrocompetentes foram preparadas conforme descrição a seguir. As amostras de $E$. coli selvagens e mutantes foram pré-cultivadas em $3 \mathrm{~mL}$ de caldo Luria-Bertani (LB) durante $18 \mathrm{~h}$ a $37^{\circ} \mathrm{C}$, sob agitação constante de $300 \mathrm{rpm}$. Uma alíquota de $0,5 \mathrm{~mL}$ desse pré-inóculo foi transferida para $50 \mathrm{~mL}$ de caldo LB e essa cultura foi então cultivada sob as mesmas condições anteriores, até atingir a absorbância de 0,5 a 0,6 em comprimento de onda de $600 \mathrm{~nm}$. As células bacterianas foram incubadas em banho de gelo por 15 min, transferidas para um tubo de centrifugação pré-resfriado e centrifugadas por 20 min a $5.000 \mathrm{~g}$ sob refrigeração de $4 \stackrel{\circ}{ } \mathrm{C}$. O sobrenadante foi descartado e 0 sedimento foi lavado duas vezes com $50 \mathrm{~mL}$ de água deionizada esterilizada resfriada a $4 \stackrel{\circ}{\circ}$. As células foram gentilmente ressuspensas em $10 \mathrm{~mL}$ de glicerol $10 \%$ resfriado a $4{ }^{\circ} \mathrm{C}$ e centrifugadas a $5.000 \mathrm{~g}$ por $10 \mathrm{~min}$ sob refrigeração a $4{ }^{\circ} \mathrm{C}$. Ao sedimento bacteriano foram adicionados $100 \mu \mathrm{l}$ de glicerol $10 \%$ resfriado a $4{ }^{\circ} \mathrm{C}$ para ressuspender as células bacterianas.

\subsubsection{Transformação por Eletroporação}

Para a transformação, foram adicionados $5 \mu \mathrm{L}$ do plasmídeo pKD46 já extraído (item 3.5.1) em $70 \mu \mathrm{L}$ de células competentes. Essa mistura foi transferida para cubetas para eletroporação de $0,1 \mathrm{~cm}$ (Biorad, EUA) previamente resfriadas e submetida à eletroporação utilizando o eletroporador GenePulser (Biorad, EUA), sob as condições de $1,5 \mathrm{kV}, 25 \mu \mathrm{F}$ e controle de pulso a $200 \Omega$.

Após a eletroporação, foi adicionado imediatamente $1 \mathrm{~mL}$ de meio SOC (triptona 2\%; extrato de levedura 0,5\%; cloreto de sódio $10 \mathrm{mM}$; cloreto de potássio 2,5 mM; sulfato de magnésio $20 \mathrm{mM}$; cloreto de magnésio $10 \mathrm{mM}$; glicose $20 \mathrm{mM}$ ) à reação, e a mesma foi incubada a $30^{\circ} \mathrm{C}$. Em seguida, os cultivos foram plaqueados nos volumes de $100 \mu \mathrm{l}, 200 \mu \mathrm{l}, 300 \mu \mathrm{l}$ em ágar LB contendo $50 \mu \mathrm{g} / \mathrm{mL}$ ampicilina e incubados a $37^{\circ} \mathrm{C}$ por $18 \mathrm{~h}$. 


\subsubsection{Mutagênese}

Em seguida, foi confeccionado um par de iniciadores (HfqMut - Tabela 2), constituídos por 2 partes contínuas, sendo a primeira uma seqüência de aproximadamente 40 bases homólogas à região upstream e downstream a hfq, e a segunda 20 bases homólogas à região FRT presente no plasmídio pKD3. Uma reação de PCR (item 3.3) foi realizada para a amplificação do cassete de resistência a cloranfenicol que foi utilizado para a mutação.

Para a etapa de recombinação gênica foram utilizadas as linhagens E2348/69pKD46, O55:H7pKD46 e o cassete de recombinação gerado por PCR. O preparo das células competentes foi feito de acordo com o item 3.5.2, exceto pela adição de ampicilina (100 $\mu \mathrm{g} / \mathrm{mL})$, para a manutenção do plasmídeo pKD46 e $1 \mathrm{mM}$ de L-arabinose (Sigma, EUA), para a indução da expressão dos genes $\mathrm{\gamma}, \beta$, e exo. Após esse procedimento, esta cultura foi crescida a $30^{\circ} \mathrm{C}$ sob agitação constante de 150 rpm até atingir a absorbância de 0,5 a 0,6 em comprimento de onda de $600 \mathrm{~nm}$.

Aproximadamente $100 \mathrm{ng}$ do cassete de recombinação foram adicionados às células competentes e a eletroporação ocorreu nas mesmas condições. Os mutantes foram selecionados em placa contendo $20 \mu \mathrm{g} / \mathrm{mL}$ de cloranfenicol. Uma vez selecionadas as amostras mutagenizadas, um par de iniciadores foi confeccionado utilizando a sequência upstream e downstream a hfq (HfqDet Tabela 2) para a realização de PCR (item 3.3).

\subsubsection{Confirmação dos mutantes}

O fragmento amplificado do gene $h f q$, bem como o produto adjacente a $h f q$, das amostras selvagens e mutantes foram purificados utilizando o GFX PCR DNA and Gel Band Purification Kit (GE Healthcare, Reino Unido), conforme recomendações do fabricante, e enviado para seqüenciamento no Centro de Estudos do Genoma Humano - USP, onde as reações foram realizadas de acordo com o sistema MegaBACE 1000, utilizando o DYEnamic ET Dye Terminator Kit (com Thermo Sequenase ${ }^{\mathrm{TM}}$ /I DNA Polimerase). Em seguida, foram comparadas às seqüências depositadas no GenBank com auxílio do programa Blast (disponível em: http://www.ncbi.nlm.nih.gov/blast/Blast.cgi). 


\subsection{Complementação}

Para complementação, foram usadas as amostras mutantes RR01 e RR03. O gene $h f q$ foi amplificado por PCR (item 3.3) com iniciadores que possuem sítios de restrição para as enzimas Xhol e EcoRI (HfqXho e HfqECO - Tabela 2). Após a amplificação, tanto o produto quanto o plasmídeo pBADMycHisA (Figura 8) foram submetidos à digestão com as enzimas Xhol e EcoRI (New England Biolabs, Reino Unido), seguindo instruções do fabricante. Após a digestão, 200 ng do gene $h f q$ e $200 \mathrm{ng}$ de pBADMycHisA digerido foi empregado em uma reação de ligação utilizando T4 DNA Ligase (Invitrogen, EUA) e sendo incubado por 2 horas à $25^{\circ} \mathrm{C}$. Em seguida, a reação de ligação foi transformada por eletroporação (itens 3.5 .2 e 3.5.3) nas amostras mutantes. Os plasmídeos transformantes foram submetidos a sequenciamento para confirmação da clonagem.

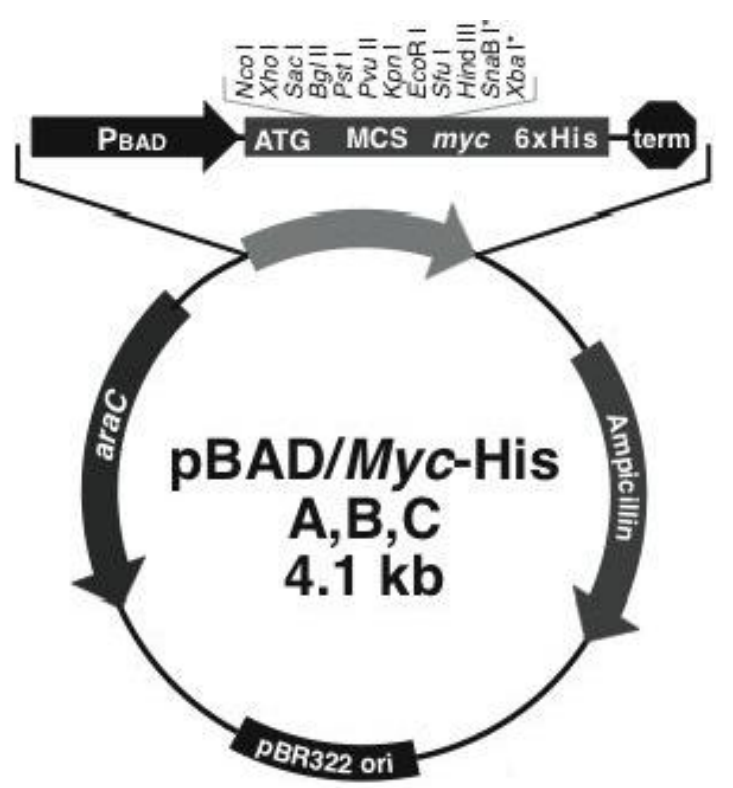

Figura 8 - Mapa ilustrativo do plasmídeo pBADMycHis. (Invitrogen, EUA) 


\subsection{RT-PCR}

O RNA total das amostras selvagens, mutantes e complementadas foi extraído seguindo recomendações dos kits $R N A$ protect ${ }^{\circledR}$ Bacteria Reagent e RNeasy® Mini Kit (QIAGEN, EUA). A reação de RT-PCR foi realizada utilizando SuperScript $B^{\circ}$ III One-Step RT-PCR System (Invitrogen, EUA). Cinquenta nanogramas do RNA tratado com DNAse (New England Biolabs, Reino Unido) foram utilizados para analizar a transcrição do gene $h f q$, utilizando o primer Hfq (Tabela 1). Uma alíquota de $10 \mu \mathrm{l}$ de cada reação foi analisada em gel de agarose $1 \%$ (item 3.4).

\subsection{Curva de crescimento}

As curvas de crescimento das amostras em estudo foram obtidas correlacionando as leituras de absorbância dos meios de cultura com determinados intervalos de tempo, segundo as condições de cultivo descritas a seguir. Inicialmente as amostras foram cultivadas a $37^{\circ} \mathrm{C}$ por $18 \mathrm{~h}$ em $3 \mathrm{~mL}$ de LB. Uma alíquota de 0,5 $\mathrm{mL}$ dessas culturas foi, em seguida, transferida a $50 \mathrm{~mL}$ de LB e esses meios foram incubados a $37^{\circ} \mathrm{C}$ sob agitação de $300 \mathrm{rpm}$. O crescimento bacteriano de cada uma das amostras foi monitorado a cada 1 hora, durante $6 \mathrm{~h}$, através de leituras de absorbância em comprimento de onda de 600 nm, utilizando o espectrofotômetro Ultrospec 2000 (Pharmacia Biotech, EUA).

\subsection{Teste de adesão em células HeLa}

A linhagem celular HeLa foi cultivada em garrafas de $50 \mathrm{ml}$ (Nunc, EUA) contendo $12 \mathrm{ml}$ de Meio Mínimo Essencial de Eagle, modificado por Dulbeco (DMEM; Cultilab, Brasil) contendo antibióticos (penicilina $1000 \mathrm{U} / \mathrm{ml}$ e estreptomicina $1 \mathrm{mg} / \mathrm{ml}$ ), acrescido de $10 \%$ de soro fetal bovino (SFB; Cultilab, Brasil), e mantidas por 2 a 3 dias a $37^{\circ} \mathrm{C}$ sob atmosfera de $5 \%$ de $\mathrm{CO}_{2}$. Após o período de incubação, as células foram transferidas para placas de 24 orifícios (Nunc, EUA) contendo lamínulas de vidro, em uma concentração de $5 \times 10^{4}$ células $/ \mathrm{ml}$, e incubadas por 48 $\mathrm{h}$ sob as mesmas condições. As amostras bacterianas foram inoculadas em $3 \mathrm{ml}$ de caldo de soja tripticaseína (TSB). Uma alíquota de $40 \mu \mathrm{l}$ da cultura bacteriana foi 
adicionada a cada orifício da placa contendo a monocamada de células HeLa, previamente lavadas por 5 vezes com PBS 1x (137 mM NaCl; 2,7 mM KCl; 4,3 mM $\mathrm{Na}_{2} \mathrm{HPO}_{4} 7 \mathrm{H}_{2} \mathrm{O} ; 1,4 \mathrm{mM} \mathrm{KH_{2 }} \mathrm{PO}_{4}$ ), e acrescidas de $960 \mu \mathrm{l}$ de meio DMEM sem antibiótico, contendo $2 \%$ de SFB e $1 \%$ de D-manose (Sigma, EUA). Após as 3 primeiras horas de incubação, as placas foram lavadas por 5 vezes com PBS 1x, acrescidas de $1 \mathrm{ml}$ de meio DMEM sem antibiótico (2\% de SFB e 1\% de D-manose), e incubadas por mais $3 \mathrm{~h}$ a $37^{\circ} \mathrm{C}$. Em seguida, foram novamente lavadas por 5 vezes com PBS 1x e fixadas com metanol absoluto. Após a fixação, as células foram coradas por 5 min com solução corante de May-Grünwald (Merck, Alemanha) e em seguida com solução corante de Giemsa (Merck, Alemanha) por 20 min. Após lavagem para retirada do excesso de corante, as lamínulas foram secas à temperatura ambiente e montadas em lâminas para microscopia com Entellan (Merck, Alemanha). As lâminas foram analisadas através de microscopia óptica, em aumento de 1.000 vezes.

\subsection{Teste de FAS (“Fluorescent actin staining”)}

As amostras bacterianas deste estudo foram submetidas a ensaios de polimerização de actina seguindo protocolo descrito por Knutton et al. (1989). O cultivo das células HeLa, bem como os ensaios de adesão em células epiteliais in vitro, foram realizados como descrito no item 3.8. Após o período de incubação e lavagens com PBS $1 \mathrm{X}$, as células foram fixadas com $p$-Formaldeído 4\% em PBS 1 $\mathrm{X}$, por $18 \mathrm{~h}$ a $4^{\circ} \mathrm{C}$. As células foram novamente lavadas com PBS $1 \mathrm{X}$ e, em seguida, permeabilizadas pela adição de Triton $0,5 \%$ em PBS $1 \mathrm{X}$, por precisamente $4 \mathrm{~min}$. Após novas lavagens, foram adicionados $5 \mu \mathrm{g} / \mathrm{ml}$ de FITC-faloidina (Molecular Probes, EUA) diluída em PBS $1 \mathrm{X}$. As placas foram incubadas por 20 min sob abrigo de luz e novamente lavadas com PBS $1 \mathrm{X}$, por três vezes de $5 \mathrm{~min}$. As lamínulas foram removidas da placa, secas com papel de filtro e fixadas sobre lâminas de vidro com a utilização de Mowiol (Sigma, EUA) adicionado de DABICO ("anti-fading"), ao qual foi acrescentado lodeto de Propídio (Molecular Probes, EUA) em uma concentração final de 1:1000. Após cerca de $20 \mathrm{~h}$ a $4{ }^{\circ} \mathrm{C}$, as lâminas foram observadas através de microscopia confocal de fluorescência em aumento de 100X (Microscópio LSM 510 Meta, Zeiss - Filtros: BP500-530IR - 488 nm; LP560 - 543 $\mathrm{nm})$. 


\subsection{Ensaio de motilidade}

A motilidade das amostras estudadas foi verificada de acordo com a metodologia empregada por Sperandio, Torres \& Kaper (2002). As amostras foram crescidas previamente por $18 \mathrm{~h}$ a $37^{\circ} \mathrm{C}$ em LB numa diluição de 1:100. Em seguida, $10 \mu \mathrm{L}$ do pré inóculo foram semeados em placas de Petri contendo 0,3\% de ágar bacteriológico, $1 \%$ de triptona e $0,25 \%$ de $\mathrm{NaCl}$ e incubados por 8 horas a $37^{\circ} \mathrm{C}$.

\subsection{Eletroforese em gel de poliacrilamida com dodecil sulfato de sódio}

A fim de avaliar o perfil proteico das amostras selvagens e mutantes, uma eletroforese em gel de poliacrilamida com dodecil sulfato de sódio (SDS-PAGE) foi realizada conforme descrito por Laemmli (1970). Após o crescimento de 16 horas das amostras em estudo, o perfil proteico celular e o perfil proteico secretado foram obtidos de acordo Sircili et al., 2004. Para eletroforese, $50 \mu \mathrm{L}$ das amostras, contendo tampão de amostra (Tris- $\mathrm{HCl} 25 \mathrm{mM}$; dodecil sulfato de sódio 8\%; glicerol 80\%; azul de bromofenol 0,04\%; pH 6,8) acrescido de $\beta$-mercaptoetanol (Sigma, EUA) na proporção de 1:20, foram aplicados em géis de concentrações de $12 \%$ de acrilamida. A eletroforese foi efetuada a $100 \mathrm{~V}$, por cerca de $1 \mathrm{~h}$ em tampão TrisGlicina (Tris base 3\%; glicina 14\%; SDS 1\%). Em seguida o gel foi corado com Comassie Brillant Blue R 250 (Merck, Alemanha) e descorado com 30\% de metanol e $7 \%$ de ácido acético.

\subsection{Western-blot e Imunodectecção}

As proteínas separadas através de SDS-PAGE foram transferidas para membranas de nitrocelulose (Amersham Biosciences, Reino Unido) através de eletroforese a $200 \mathrm{~mA}$ por $2 \mathrm{~h}$. Em seguida, foram bloqueadas durante $2 \mathrm{~h}$ com uma solução a 5\% de leite em pó desnatado (Molico - Nestlé, Brasil) em PBS pH 7,4 contendo 0,05\% de Tween 20 (PBS-Tween).

Após o bloqueio, as membranas foram submetidas à imunodetecção empregando o anti-soro policlonal contra a proteína EspA, gentilmente cedido pela Dra. Roxane Maria Fontes Piazza, do Laboratório de Bacteriologia do Instituto Butantan. Durante $2 \mathrm{~h}$, as membranas ficaram em contato com o anti-soro na 
concentração de $50 \mathrm{ng} / \mathrm{mL}$, diluídos em PBS-Tween contendo $1 \%$ de leite em pó desnatado (Molico - Nestlé, Brasil). Para a imunodetecção foi utilizado o $E C L^{\mathrm{TM}}$ Western Blotting Analysis System (Amersham, Reino Unido), e a exposição foi realizada no Hyperfilm ECL ${ }^{\mathrm{TM}}$ (Amersham, Reino Unido), seguindo recomendações do fabricante.

\subsection{PCR em Tempo Real}

A análise quantitativa da transcrição dos genes da região LEE das amostras selvagens e das mutantes, foram reazlizadas por PCR em tempo real, utilizando o KAPA ${ }^{\text {TM }}$ SYBR® FAST One-Step qRT-PCR Kit (KAPABIOSYSTEMS, EUA). Para cada reação, 50 ng do RNA extraído (item 3.7) foi adicionado à mistura dos iniciadores (Tabela 3). Os dados foram analizados utilizando LineGene 9600 (Bioer) e o controle transcricional endógeno foi gene o rpoA. Os níveis transcricionais dos genes estudados foram quantificados pelo método de quantificação relativa e expressos como diferenças comparadas com os níveis das amostras selvagens. A barra de erro representa o desvio padrão dos valores de $C_{t}$ (critic threshold) nas triplicatas.

Tabela 3. Sequência dos iniciadores utilizados nos ensaios de qRT-PCR.

\begin{tabular}{lll}
\hline Iniciadores & \multicolumn{1}{c}{ Sequência (5'- 3') } & \multicolumn{1}{c}{ Referência } \\
\hline espA_RT_F1 & TCAGAATCGCAGCCTGAAAA & Walters; Sperandio, 2006 \\
espA_RT_R1 & CGAAGGATGAGGTGGTTAAGCT & Walters; Sperandio, 2006 \\
eae_RT_F1 & GCTGGCCCTTGGTTTGATCA & Walters; Sperandio, 2006 \\
eae_RT_R1 & GCGGAGATGACTTCAGCACTT & Walters; Sperandio, 2006 \\
ler_RT_F1 & CGACCAGGTCTGCCCTTCT & Walters; Sperandio, 2006 \\
ler_RT_R1 & GCGCGGAACTCATCGAAA & Walters; Sperandio, 2006 \\
fliCRTF & TCCATCGACAAATTCCGTTCT & Habdas et al, 2010 \\
fliCRTR & TGGTGACTGCGGAATCCA & Habdas et al, 2010 \\
$r p o A R T F$ & GCGCTCATCTTCTTCCGAAT & Walters; Sperandio, 2006 \\
$r p o A R T R$ & CGCGGTCGTGGTTATGTG & Walters; Sperandio, 2006 \\
\hline
\end{tabular}




\subsection{Extração de Small RNA}

O sRNA total das amostras de Escherichia coli típica e atípica, e das amostras mutantes, foi extraído através do kit PureLink ${ }^{\mathrm{TM}}$ miRNA Isolation Kit (Invitrogen, EUA), segundo recomendações do fabricante. Foi adicionado às preparações, previamente tratadas com DNAse (New England Biolabs, Reino Unido), $5 \mu \mathrm{l}$ de tampão de amostra $1 \mathrm{X}$ (azul de bromofenol 0,25\%, xileno cianol $0,25 \%$, glicerol $30 \%$ ) e essas foram aquecidas por 5 min à $95{ }^{\circ} \mathrm{C}$. As amostras foram visualizadas através da separação eletroforética em gel de poliacrilamida em condição desnaturante (TAE 1X, 7 M Ureia, 15\% Poliacrilamida). Como marcador de peso molecular, foi utilizado o 100 pb DNA Ladder (Invitrogen, EUA). Antes de adicionar as amostras, foi realizada um pré-corrida de $30 \mathrm{mim}$ sob corrente constante de $150 \mathrm{~V}$, em tampão TAE 1 X. Após a corrida eletroforética, realizada sob corrente constante de $100 \mathrm{~V}$ em tampão TAE $1 \mathrm{X}$, os géis foram corados em solução de brometo de etídio na concentração de $10 \mu \mathrm{g} / \mathrm{mL}$ durante 10 a $20 \mathrm{~min}$, e observados em transiluminador de luz ultravioleta.

\subsection{Análise in silico do RNA Mensageiro de ler}

Com o intuito de fazer uma análise do comportamento do RNA mensageiro de ler quanto à sua estrutura secundária, foi realizada uma análise in silico. A sequência de ler foi obtida através do banco de dados (Número de acesso do GenBank: NC_011601.1) e o seu promotor foi identificado com base nos resultados obtidos por Jeong et al., 2012. A análise foi feita on line no RNAfold Web Server (http://rna.tbi.univie.ac.at/cgi-bin/RNAfold.cgi). 


\section{RESULTADOS}

\subsection{Construção do mutante $h f q$}

O objetivo deste estudo foi avaliar a participação de Hfq na regulação de processos patogênicos de Escherichia coli enteropatogenica tipica e atípica. Como Hfq é uma proteina com função de chaperonina, optou-se pela mutação do gene hfq através da metodologia descrita por Dtasenko e Wanner (2002). Inicialmente, foi avaliada a presença do gene nas amostras em estudo. Foi confeccionado um par de inicadores para a amplificação de um fragmento de 309 pb, correspondente ao gene hfq (Figura 9).

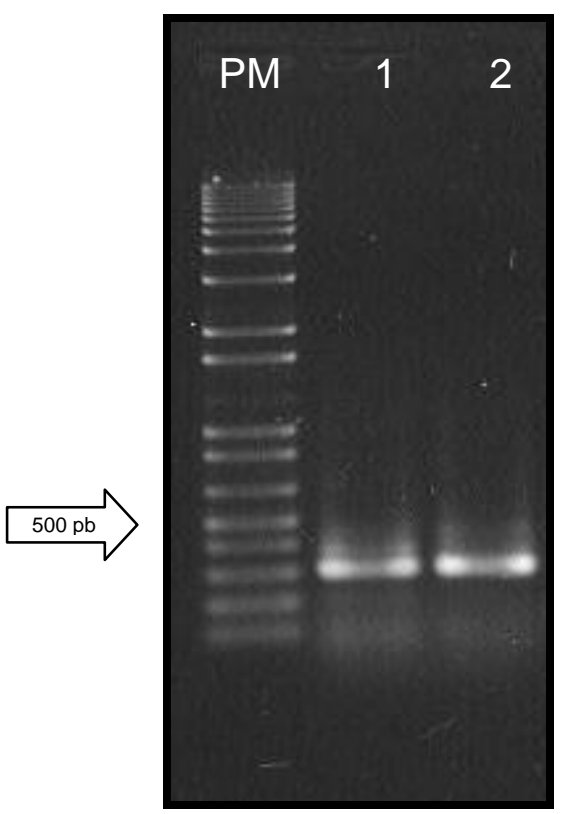

Figura 9 - Eletroforese em gel de agarose dos produtos da amplificação do gene $h f q$ (309 pb). PM - 1 kb Plus Invitrogen, EUA; 1 - Amostra O127:H6; 2 - O55:H7. 
Para a construção do mutante em hfq das amostras de Escherichia coli Enteropatogênica tipica do sorotipo 0127:H6, e atípica do sorotipo O55:H7, foi amplificado o cassete de resistência ao cloranfenicol (figura 10), flanqueado pelas regiões FRT, utilizando os iniciadores Hfq_Mut_Fe Hfq_Mut_R (Tabela 2).

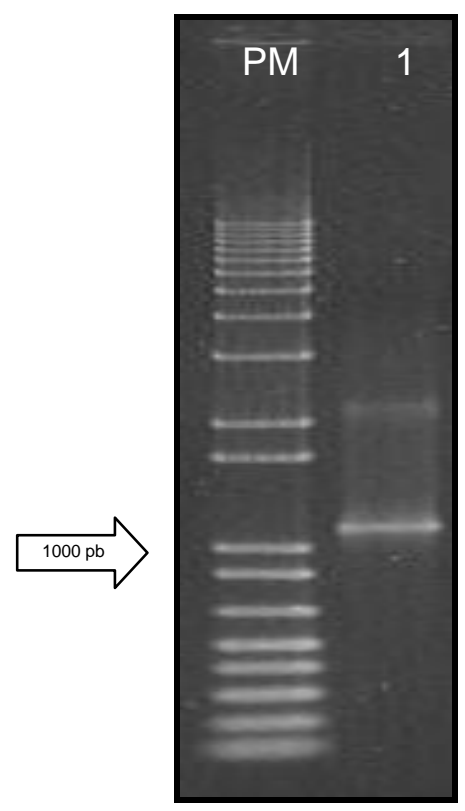

Figura 10 - Eletroforese em gel de agarose $1 \%$ do produto da amplificação do cassete de resistência cat (1094 pb). PM - 1 kb Plus Invitrogen, EUA; 1 - pKD3 (Cloranfenicol).

As amostras em estudo, previamente transformadas com o plasmídeo pKD46, foram submetidas à eletroporação para transformação com o cassete de resistência. As colônias transformantes foram submetidas inicialmente a uma reação de PCR utilizando os iniciadores $H f q \_F$ e $H f q \_R$. Na figura 11 , observa-se a ausência de

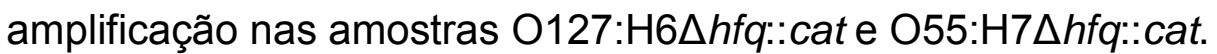




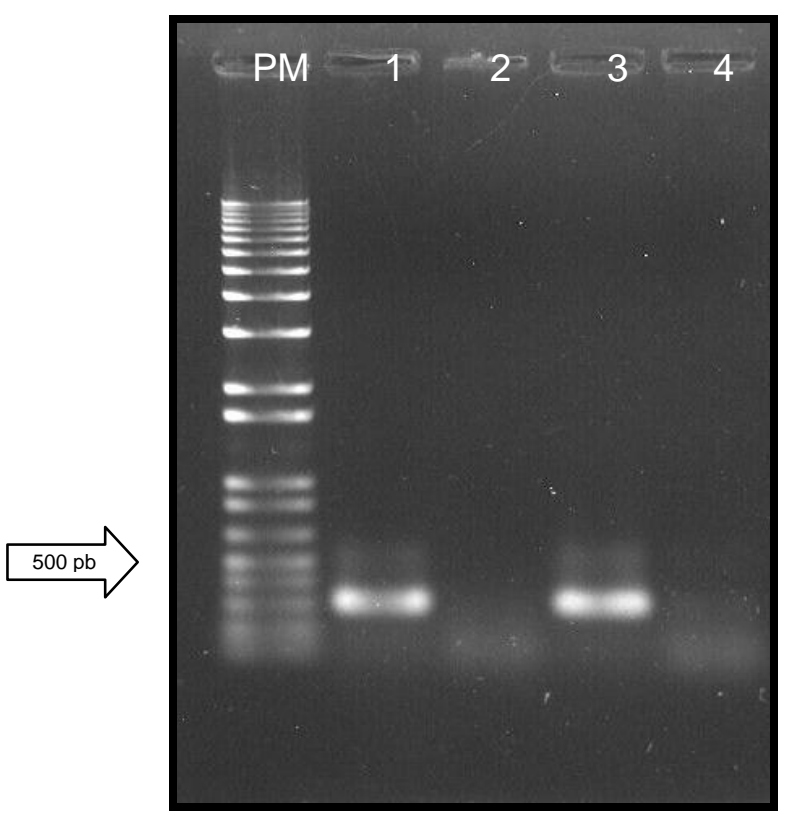

Figura 11 - Eletroforese em gel de agarose dos produtos da amplificação do gene $h f q . P M-1 \mathrm{~kb}$ Plus Invitrogen, EUA; 1 - Amostra E2348/69; 2 - E2348/69Ahfq::cat; 3 - O55:H7, 4 O55:H7 $\Delta h f q:$ :cat.

Em seguida, utilizando os iniciadores Hfq_Det_F e Hfq_Det_R, uma reação de PCR foi realizada e o produto da amplificação foi enviado para sequenciamento. O resultado foi analisado pelo programa Blast (disponível em: http://www.ncbi.nlm.nih.gov/blast/Blast.cgi) e demonstrou identidade apenas com o gene $h f q$, para as amostras selvagens, e o gene cat, para as amostras mutantes, depositados no GenBank. As similaridades variaram entre 96 e 99\%. Nas figuras 12 e 13 estão apresentados os resultados dos alinhamentos. 
Escherichia coli 0127:H6 E2348/69 complete genome, strain E2348/69

Sequence ID: emb|FM180568.11 Length: 4965553 Number of Matches: 1

Range 1: 4747468 to 4748215 GenBank Graphics

\begin{tabular}{lllll}
\hline Score & Expect & Identities & Gaps & Strand \\
1351 bits $(731)$ & 0.0 & $742 / 748(99 \%)$ & $3 / 748(0 \%)$ & Plus/Plus \\
\hline
\end{tabular}

Features: delta(2)-isopentenylpyrophosphate tRNA-adenosine transferase HF-I, host factor for RNA phaqe Q beta replication

Query 3 TGGCG-A-CGGCAGAT-ACCTGGCTGCGTGGTTGGGAAGGGGTICACTGGCTTGACAGTG

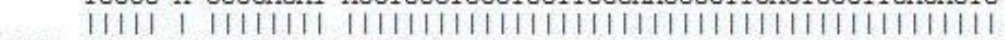

Sbjet 4747468 TGGCGAAGCGGCAGATAACCTGGCTGCGTGGTTGGGAAGGGGTTCACTGGCTTGACAGTG

Query 60 AAAAACCMSAACAGGCGCGTGATGAAGTATTACAGGTTGTTGGTGCTATCSCAGGCTGAA

Sbjet 4747528 AAAAACCAGAACAGGCGCGTGATGAAGTATTACAGGTTGTTGGTGCTATCGCAGGCTGAA 119

Sbjet 4747528 AAAAACCAGAACAGGCGCGIGATGAAGIATIACAGGITGIIGGIGCTAICGCAGGCIGA 4747587

Query 120 IGTGTACAATTGAGACGTATCGTGCGCAATTTTTTCAGAATCGAAAGGTTCAAAGTACAA 179

Sbjet 4747588 TGTGTACAATTGAGACGTATCGTGCGCAATTTTTTCAGAATCGAAAGGTTCAAAGTACAA

Query 180 ATAAGCATATAAGGAAAAGAGAGAATGGCTAAGGGGCAATCTTTACAAGATCCGTTCCTG

Sbjet 4747648 ATAAGCATATAAGGAAAGAGAGATGGCTAAGgGGCATCTTAACAAGATCCGTTCCTG 4747647 239

Query 240 AACGCACTGCGTCGGGAACGTGTTCCAGTTTCTATTTATTTGGTGAATGGTATTAAGCTG 4747707

Sbjet 4747708 AACGCACTGCGTCGGGAACGTGTTCCAGTTTCTATTTATTTGGTGAATGGTATTAAGCTG

Query $300 \quad$ CAAGGACAAATCGAGTCTTTTGATCAGTTCGTGATCCTGTTGAAAAACACGGTCAGCCAG

1111111111111111111111111111111111111111111111111111111111111

Sbjet 4747768 CAAGGACAAATCGAGTCTTTTGATCAGTTCGTGATCCTGTTGAAAAACACGGTCAGCCAG

Query 360 ATGGTTAAAAGCACGCGATTICTACTGTTGTCCCGTCTCGCCCGGTTTCTCATCACAGT

111111111111111111111111111111111111111111111111111111111111

Sbjct 4747828 ATGGTTTACAAGCACGCGATTTCTACTGTTGICCCGTCTCGCCCGGTTTCTCATCACAGT

Query 420 AACAACGCCGGTGGCGGTACCAGCAGTAACTATCATCATGGTAGCAGCGCGCAGAATACT

Query 420

Sbjet 4747888 AACAACGCCGGTGGCGGTACCAGCAGTAACTATCATCATGGTAGCAGCGCGCAGAATACT

Query 480 ICCGCGCAACAGGACAGCGAAGAAACCGAATAAGGTTTCGGGCIGttttttACACGGGG

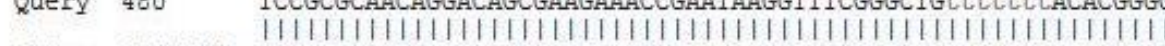

Sbjet 4747948 TCCGCGCAACAGGACAGCGAAGAAACCGAATAAGGTTTCGGGCTGTTITTTTACACGGGG

Query 540 AGCCAGCGATCCTGCGTTCCCCGCTGATCTATTTAGAGGGTTATACGCTTGTTTGACCGT

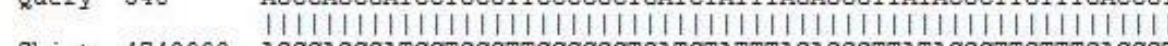

Sbjet 4748008 AGCCAGCGATCCTGCGTTCCCCGCTGATCTATTTAGAGGGTTATACGCTTGTTTGACCGI

Query 600 TATGATGCTGGTGAGCAGGCGGTACTGGTACACATCTATTTTACGCAAGACAAAGATATG

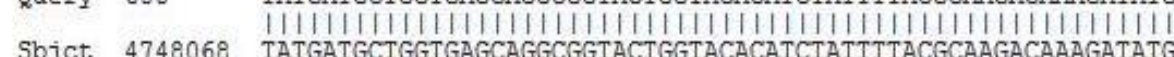

Sbjet 4748068 TATGATGCTGGTGAGCAGGCGGTACTGGTACACATCTATTTTACGCAAGACAAAGATATG

Query 660 GAAGACCTCCAGGAGTTTGAATCTCTGGTCTCTTCCGCCGGTGTCGAAGCATTGCAGGTG Sbjet 4748128 GAAGACCTCCAGGAGTTTGATCTCTGGTCTCTTCCGCCGGTGTCGAAGCATTGCAGGTG $4748811 \|$

Query 720 ATTACCGGTAGCCGTAAAGCGCCGCACC 747

1111111111111111111111111111

Sbict 4748188 ATTACCGGTAGCCGTAAAGCGCCGCACC 4748215

Figura 12 - Análise do alinhamento gerado pelo programa Blast utilizando os iniciadores Hfq_Det_Fe $H f q \_D e t \_R$ das amostras selvagens. 


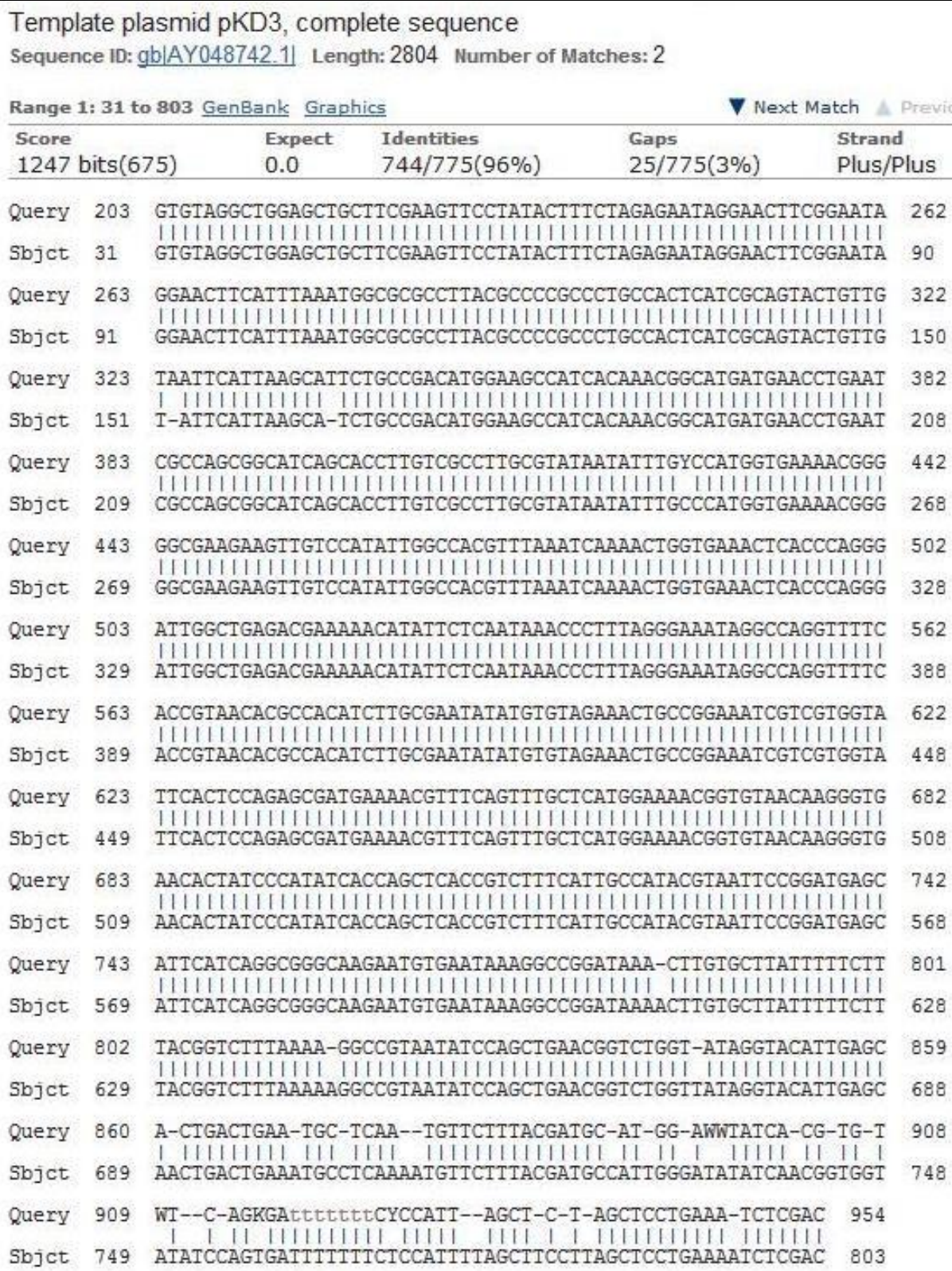

Figura 13 - Análise do alinhamento gerado pelo programa Blast utilizando os iniciadores Hfq_Det_Fe $H f q \_$Det_R das amostras mutantes.

Para complementaçãodas amostras mutadas em $h f q$, pares de iniciadores (HfqXho e HfqEco) foram confeccionados a partir da sequencia de $h f q$ e da sequencia do vetor de clonagem pBADMycHisA. Isso, para que no momento da transcrição, o RNA mensageiro fosse mantido em fase de leitura para a tradução. Sendo assim, a reação de PCR utilizando esses iniciadores foi realizada, e os 
produtos da amplificação bem como o vetor de clonagem, foram submetidos à digestão enzimática. Em seguida, foram empregados em uma reação de ligação e transformados por eletroporação. Para confirmar a transformação, as amostras foram submetidas à uma reação de PCR utilizando os iniciadores $H f q \_F / R$ e Hfq_Det_F/ R. O perfil da amplificação está apresentado na figura 14 e confirma a transformação, uma vez que as amostras mutantes complementadas com o gene hfq apresentam a amplificação do mesmo.

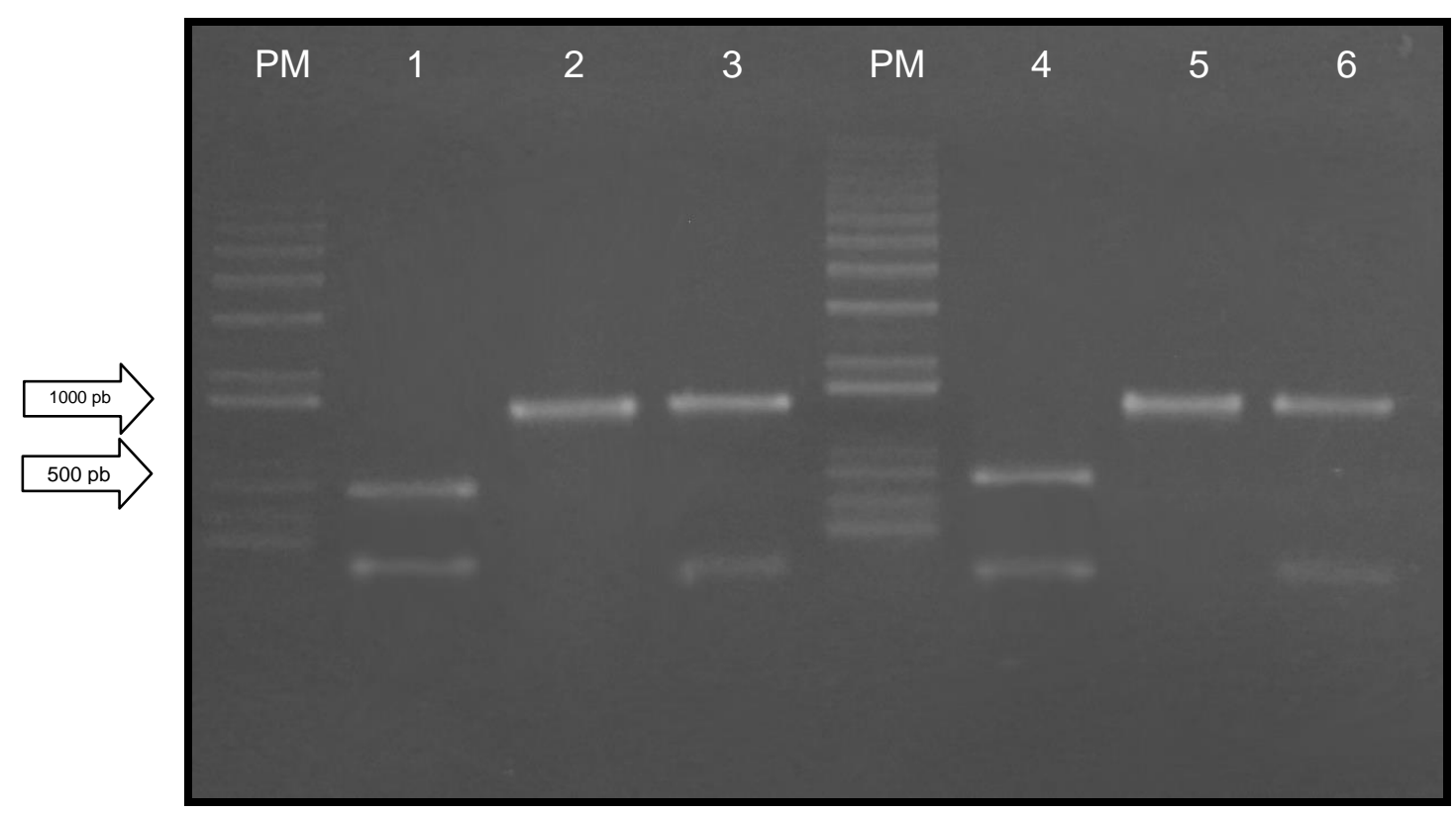

Figura 14 - Eletroforese em gel de agarose dos produtos de amplificação utilizando iniciadores: Hfq_F/ R (309 pb) e Hfq_Det_F/ R (797 pb nas amostras selvagens e 1582 pb nas amostras mutantes). 1 - 1 kb Plus Invitrogen, EUA; 2 - O127:H6; 3 - O127:H6 $\Delta$ fq:::cat; 4 - O127:H6 $\Delta$ hfq::cat

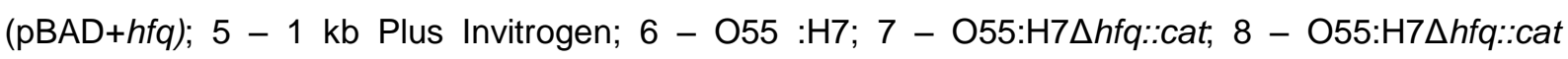
(pBADhfq).

\subsection{Análise transcricional do gene $h f q$}

Após a complementação, as amostras selvagens (O127:H6 e O55:H7),

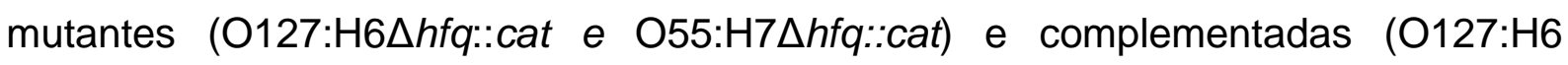
$\Delta h f q::$ cat (pBAD+hfq) e 055:H7 $\Delta h f q:: c a t(\mathrm{pBAD} h f q))$ tiveram seu RNA total extraído, 
com o intuito de avaliar os níveis de transcrição do gene $h f q$. Os RNAs foram transformados em cDNA, através da transcriptase reversa, e submetidos à uma reação de PCR utilizando os iniciadores $H f q \_F$ e $H f q \_R$. Na figura 15 observa-se que nas amostras selvagens e complementadas houve amplificação, enquanto na amostra mutante não houve, indicando a ausência de RNA mensageiro referente ao gene $h f q$.

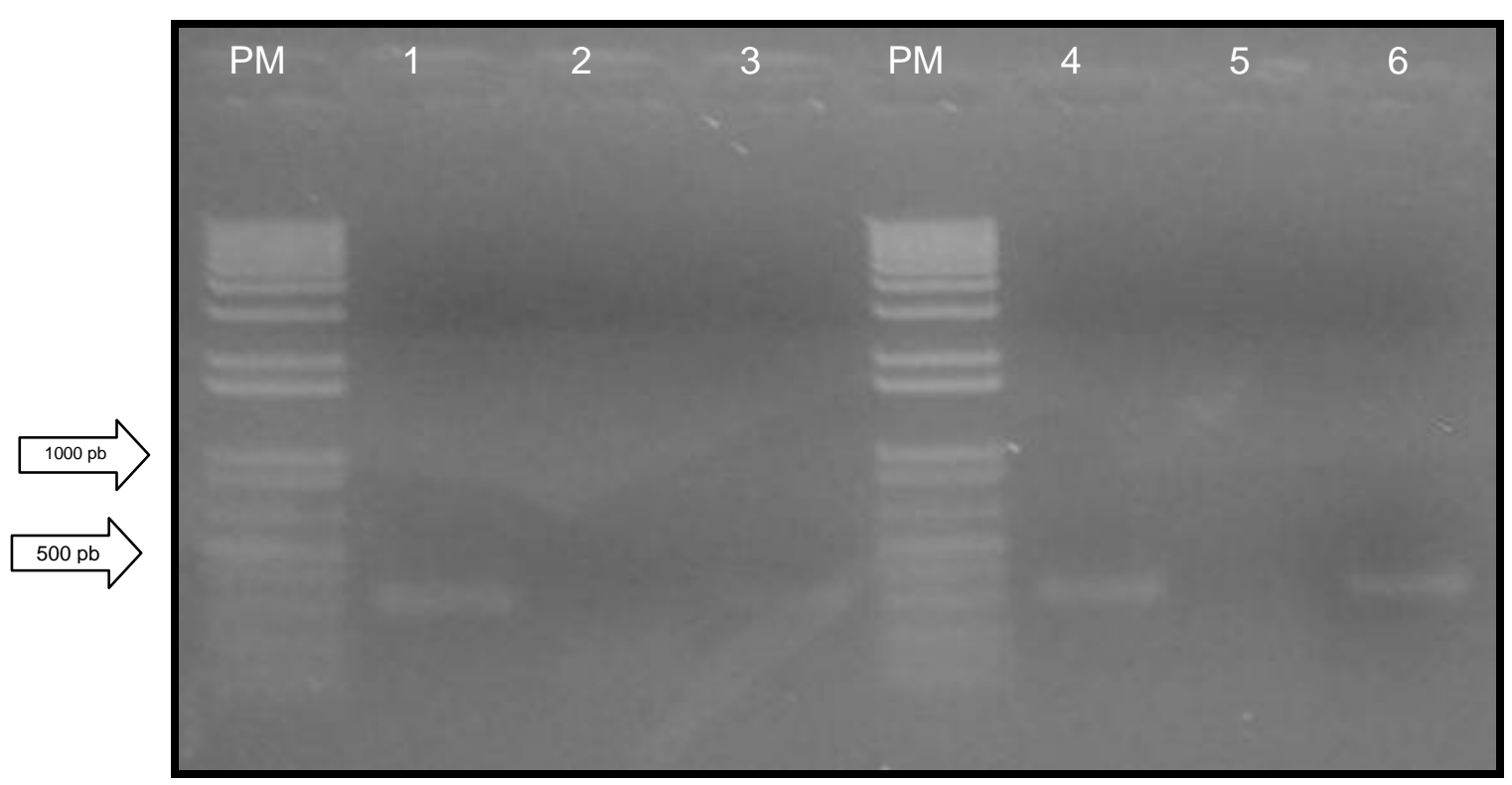

Figura 15 - Eletroforese em gel de agarose dos produtos de amplificação utilizando os iniciadores Hfq_F/ R (309 pb). 1 - 1 kb Plus Invitrogen, USA; 2 - O127:H6; 3 - O127:H6 4 hfq::cat; 4 - O127:H6 $\Delta h f q::$ cat $(\mathrm{pBAD}+h f q) ; 5$ - $1 \mathrm{~kb}$ Plus Invitrogen; 6 - O55 :H7; 7 - O55:H7Ahfq::cat; 8 O55:H7Ahfq::cat (pBADhfq).

\subsection{Curva de Crescimento}

No intuito de avaliar o perfil de crescimento das amostras em estudo, foi realizada uma curva de crescimento em caldo TSB sob agitação constante de 300 rpm a $37^{\circ} \mathrm{C}$. Nota-se na figura 16 , referente às amostras selvagem, mutante e 
complementada do sorotipo $0127: \mathrm{H} 6$; e na figura 17, referente às amostras selvagem, mutante e complementada do sorotipo O55:H7, um comportamento semelhante para atingir a fase log de crescimento, indicando que a mutação não alterou a taxa de crescimento destas amostras.

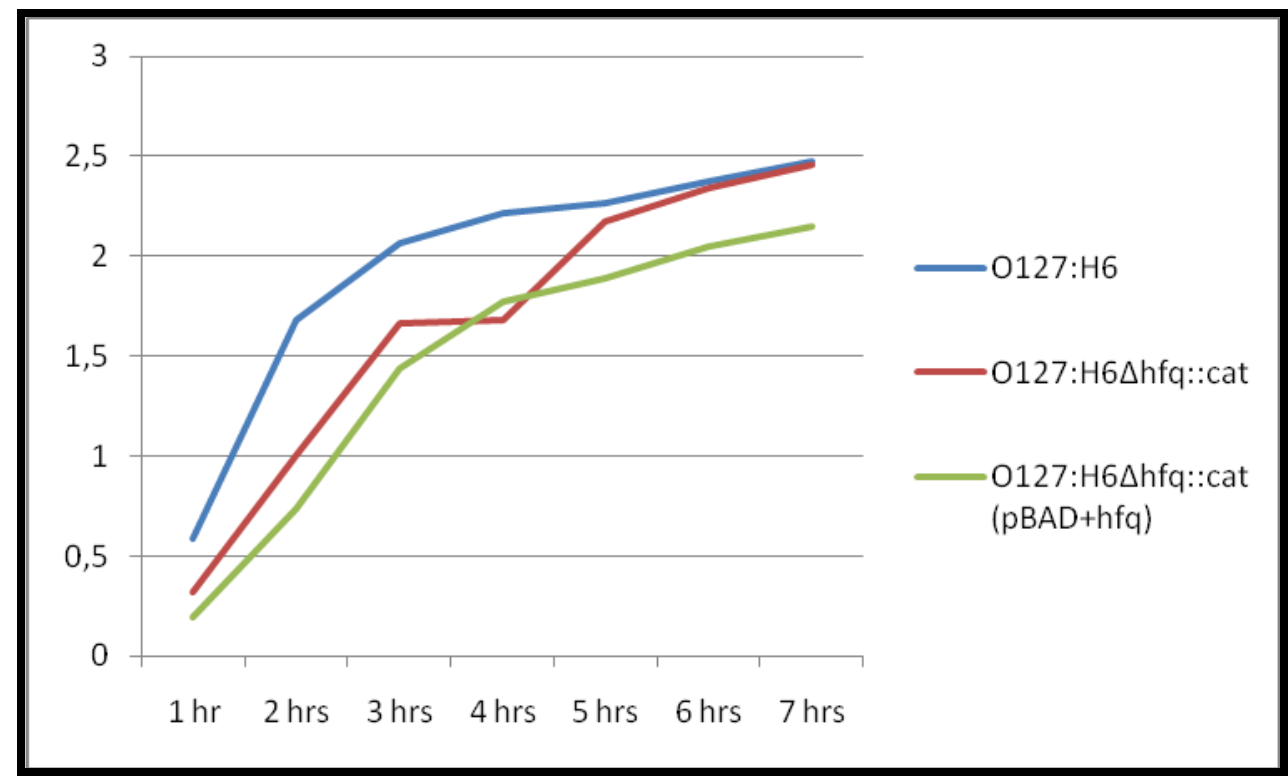

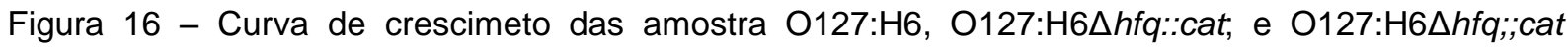
(pBAD+hfq) em caldo TSB cultivado sob agitação constante de $300 \mathrm{rpm}$ a $37^{\circ} \mathrm{C}$. As absorbâncias em comprimento de onda de $600 \mathrm{~nm}$ foram obtidas em intervalos de 30 min por um período de $7 \mathrm{~h}$. 


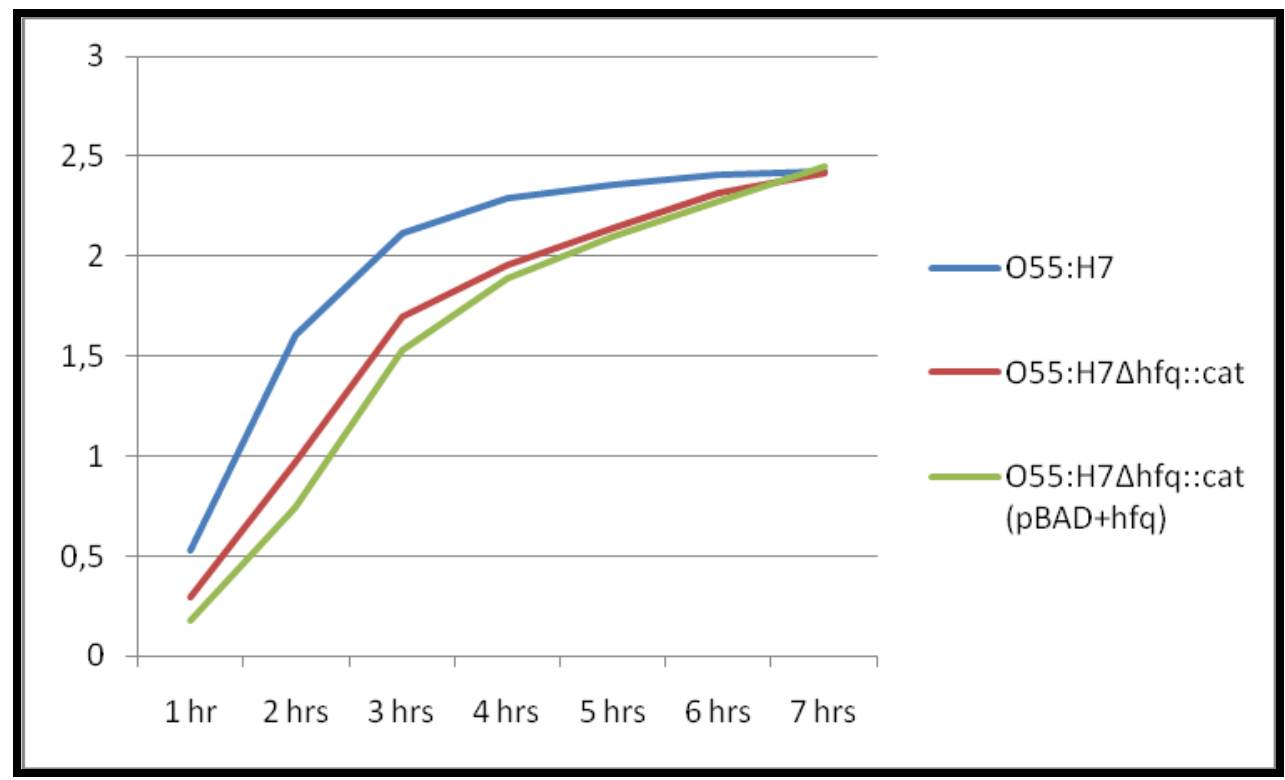

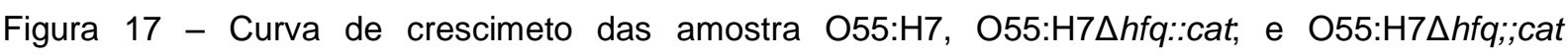
(pBAD+hfq) em caldo TSB cultivado sob agitação constante de $300 \mathrm{rpm}$ a $37^{\circ} \mathrm{C}$. As absorbâncias em comprimento de onda de $600 \mathrm{~nm}$ foram obtidas em intervalos de 30 min por um período de $7 \mathrm{~h}$.

\subsection{Análise Fenotípica}

\subsubsection{Teste de Adesão}

Como primeira análise fenotípica foi realizado o teste de adesão em células epiteliais in vitro (CRAVIOTO et al., 1979), com o intuito de observar se o padrão de adesão localizada na amostra de EPEC típica (SCALETSKY et al., 1984) e o padrão de adesão localizada-like nas amostras de EPEC atípica (PELAYO et al., 1999; RODRIGUES et al., 1996; SCALETSKY et al., 1999) foi alterado nas amostras mutantes. Nas figuras 18 e 19 estão apresentados os padrões de adesão das amostras em estudo. Observa-se que a amostra E2348/69 mutante manteve o padrão de adesão localizada, porém o número de bactérias aderidas parece ser menor. Por outro lado, na amostra 055:H7 mutante não foi possível observar o padrão de adesão localizada-like, apenas um número muito pequeno de bactérias aderidas aleatoriamente. As amostras complementadas apresentaram padrão semelhante ao das amostras selvagens. 

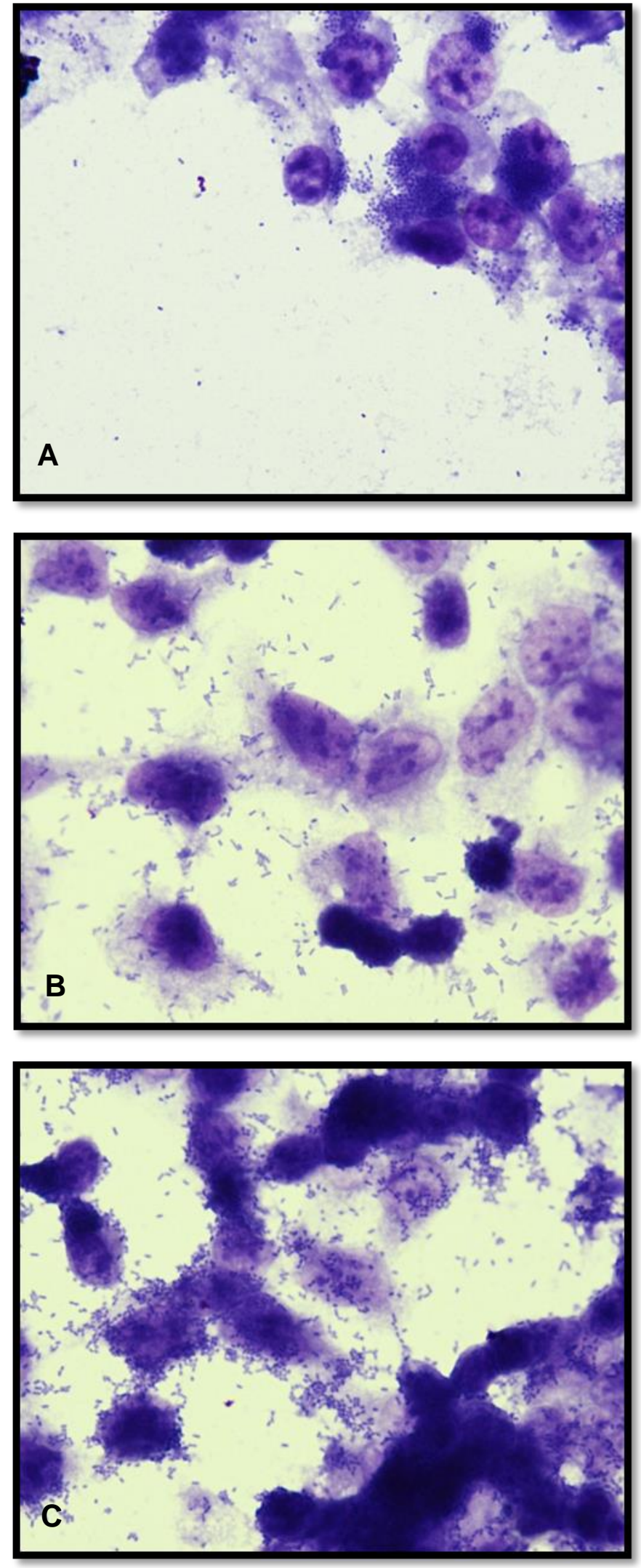

Figura 18 - Teste de adesão em células HEp-2 após 6h de interação bactérias-células epiteliais. As células foram coradas com solução de May-Grünwald/Giemsa e observadas em microscópio óptico

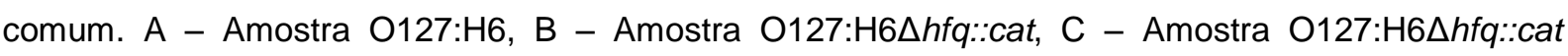
(pBAD+hfq). Aumento: 1.000 vezes. 

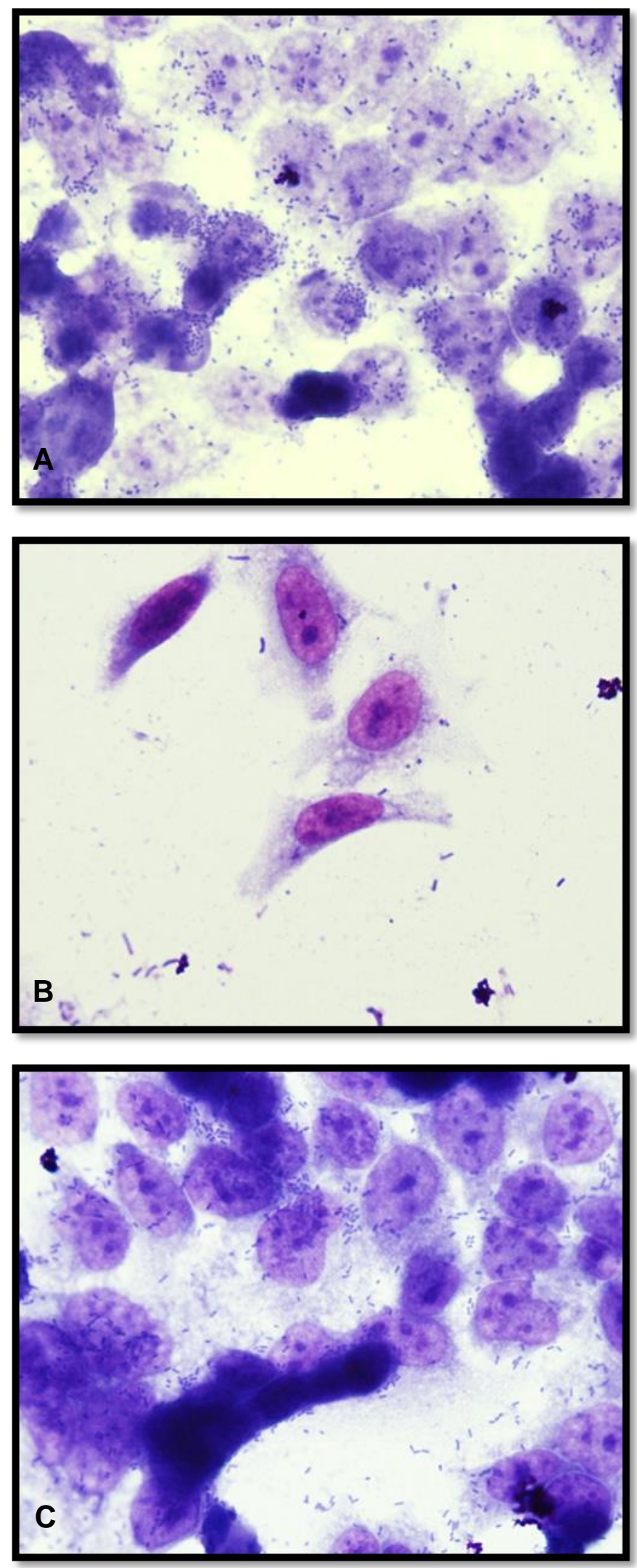

Figura 19 - Teste de adesão em células HEp-2 após 6h de interação bactérias-células epiteliais. As células foram coradas com solução de May-Grünwald/Giemsa e observadas em microscópio óptico

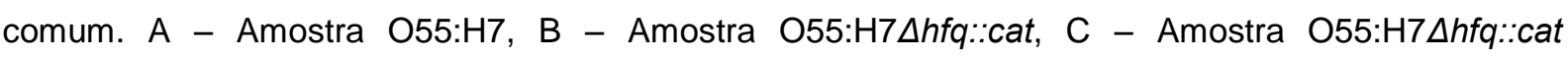
$(\mathrm{pBAD}+h f q)$. Aumento: 1.000 vezes. 


\subsubsection{FAS}

A lesão $A / E$, característica da patogênese de EPEC, pode ser observada através do teste de FAS, que foi realizado com o objetivo de avaliar se os mutantes em $h f q$ ainda seriam capazes de apresentar este fenótipo. Através deste ensaio é possível detectar o acúmulo de actina polimerizada no ponto onde a bactéria encontra-se aderida, referente aos pedestais indicativos da lesão $A / E$, por meio de coloração diferencial. Na figura 20, nota-se que a amostra 0127:H6 mutante foi capaz de formar a lesão $A / E$, porém observa-se um número aparentemente menor de pedestais com relação à amostra selvagem, e a restauração do fenótipo na amostra complementada. O comportamento das amostras do sorotipo O55:H7 foi o mesmo, apresentado na figura 21 , em que mutante não foi capaz de formar a lesão A/E. 

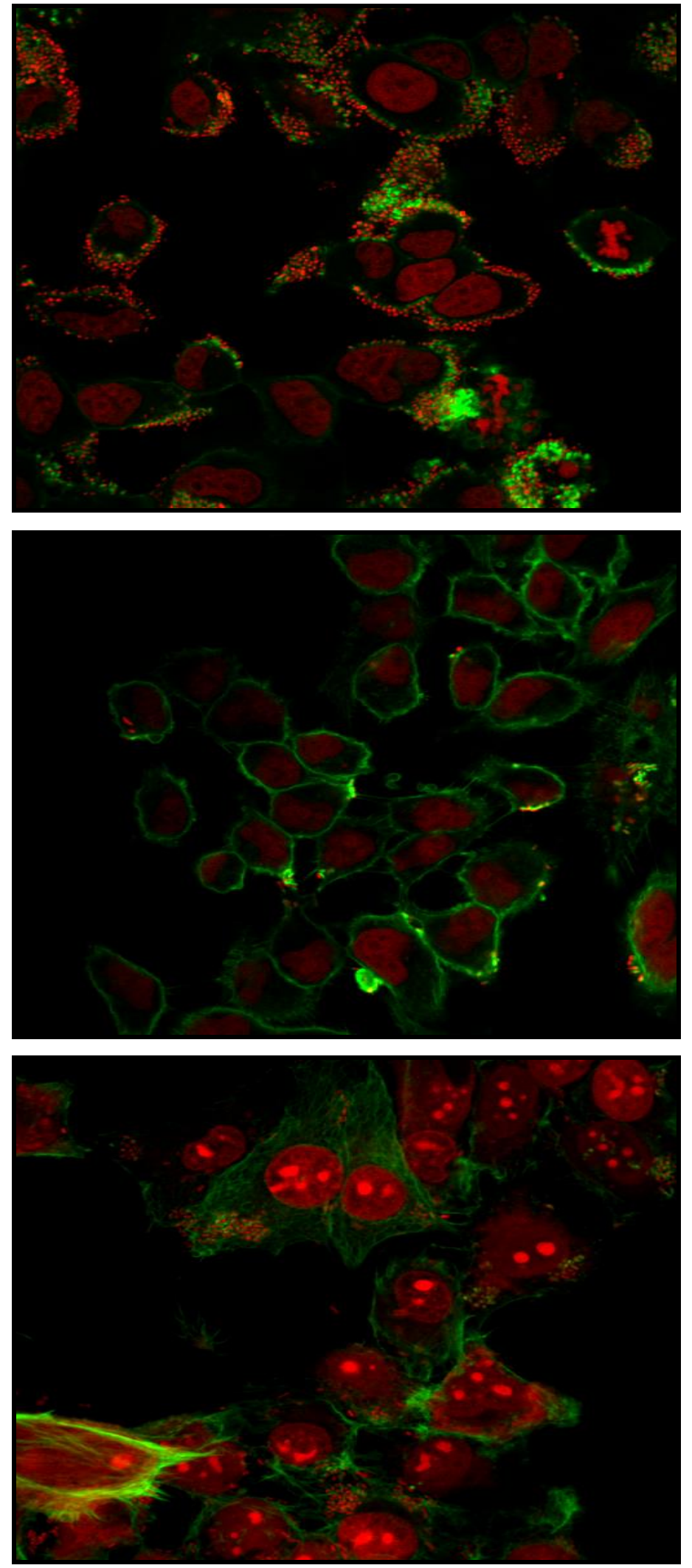

Figura 20 - Ensaio de formação da lesão A/E de 6 horas de interação das amostras com células HeLa. As células foram duplamente marcadas com FITC-faloidina (actina polimerizada - verde) e iodeto de propídio (DNA - vermelho). As amostras foram visualizadas através de microscopia de fluorescência em aumento de 1000X. A - E2348/69, C - E2348/69 $\Delta h f q:: c a t, \Delta h f q:: c a t$. 

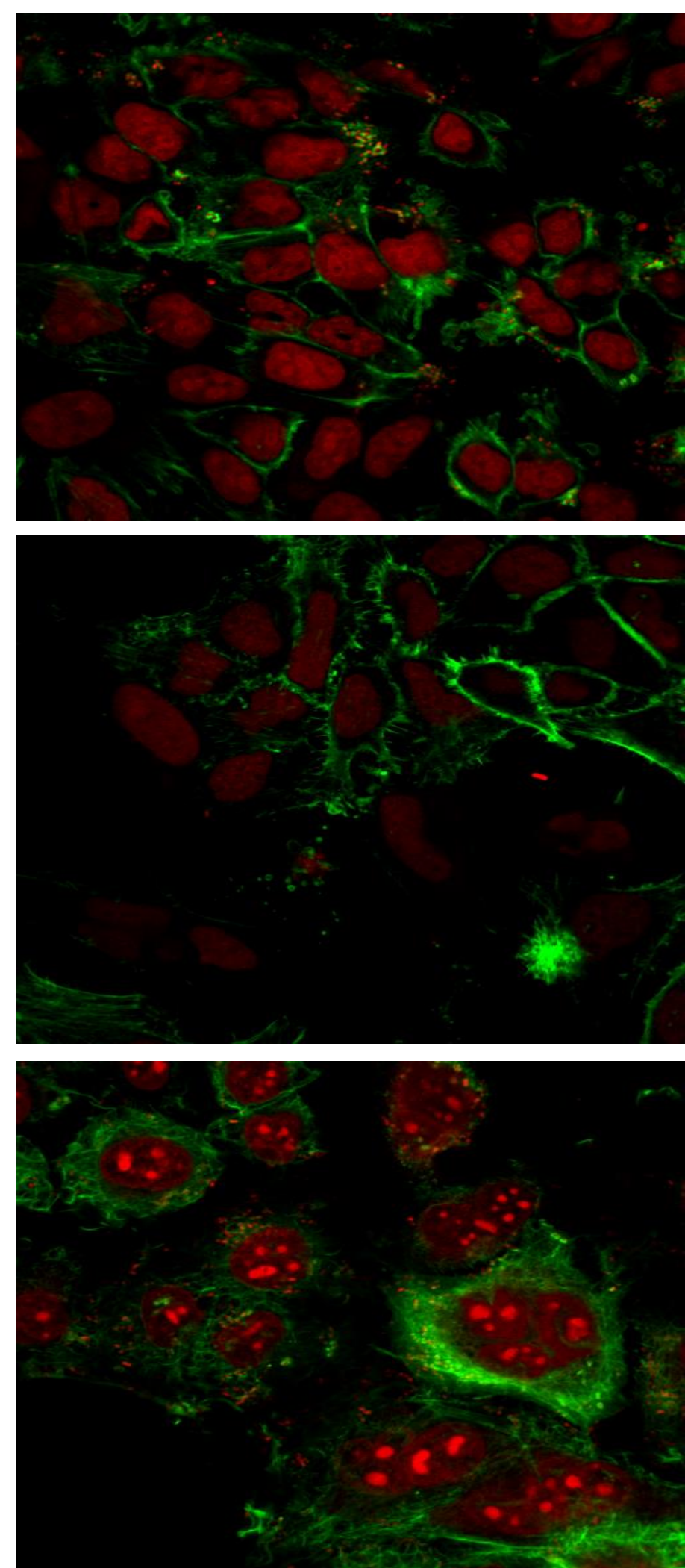

Figura 21 - Ensaio de formação da lesão A/E de 6 horas de interação das amostras com células HeLa. As células foram duplamente marcadas com FITC-faloidina (actina polimerizada - verde) e iodeto de propídio (DNA - vermelho). As amostras foram visualizadas através de microscopia de fluorescência em aumento de 1000X. A - E2348/69, C - E2348/69 $\Delta$ hfq::cat, $\Delta$ hfq::cat. 


\subsubsection{Análise Proteica}

A caracterização do perfil proteico das amostras mutantes deste estudo foi realizada em comparação ao perfil das amostras selvagens com o objetivo de analisar qualitativamente a perda da expressão de alguma dessas proteínas, uma vez que os dados da literatura demonstram a participação de Hfq na regulação pós transcricional. Nas figuras 22 e 23, é apresentado o perfil proteico das amostras do sorotipo 0127:H6 e 055:H7, respectivamente. É possível identificar uma diminuição quanto a concentração das proteínas nas amostras mutantes.

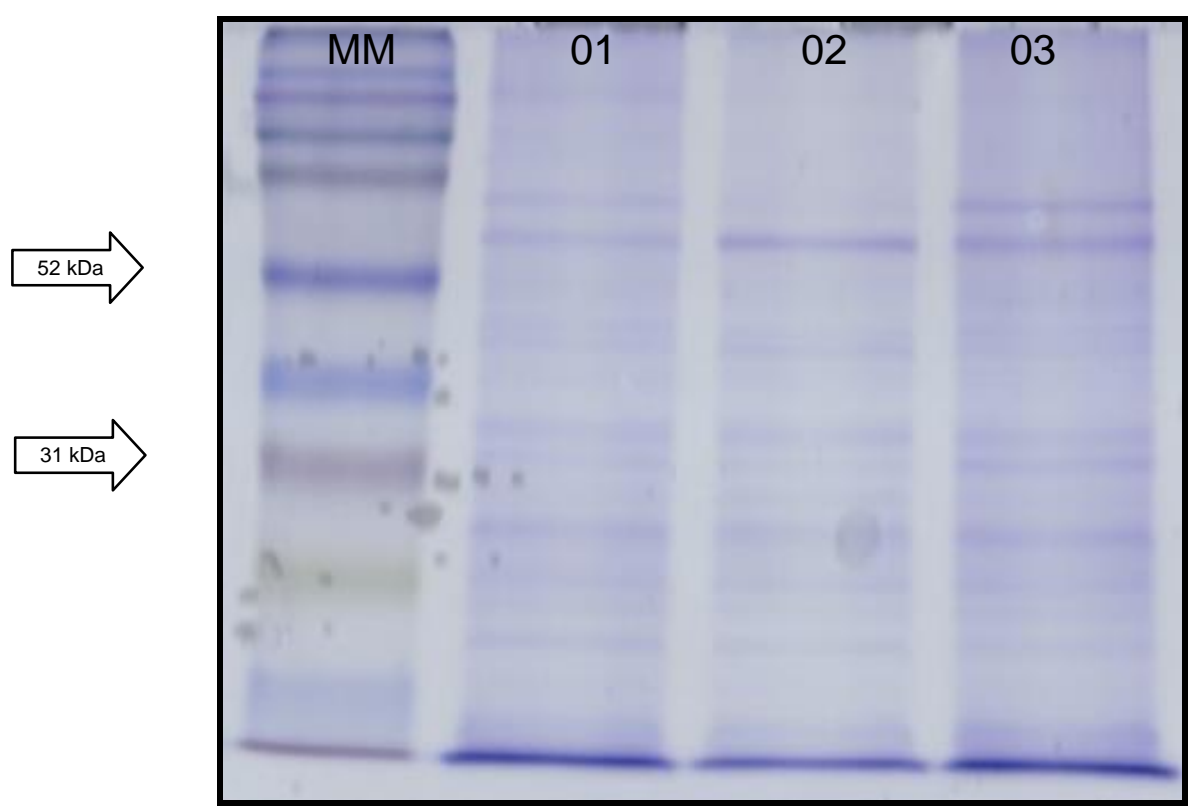

Figura 22 - Eletroforese em gel de poliacrilamida com dodecil sulfato de sódio (12\%) dos extratos proteicos totais das amostras deste estudo, corado por Comssie Blue. MM, marcador de massa molecular Protein mixture (GE Healthcare), 1 - Amostra O127:H6, 2 - Amostra O127:H6 4 hfq::cat, 3 Amostra O127:H6 $\Delta$ hfq::cat (pBAD+hfq). 


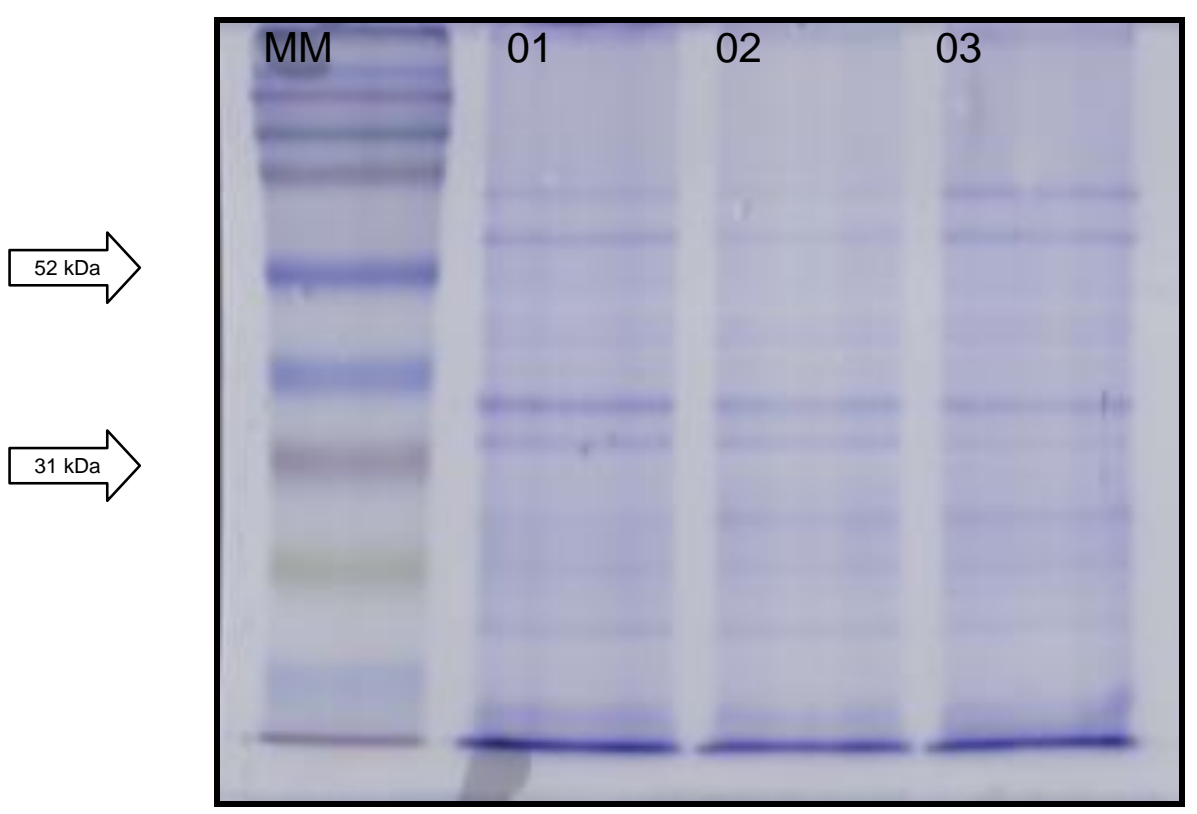

Figura 23 - Eletroforese em gel de poliacrilamida com dodecil sulfato de sódio (15\%) dos extratos proteicos totais das amostras deste estudo, corado por Comassie Blue. MM - marcador de massa molecular Protein mixture (GE Healthcare), 1 - Amostra O55:H7, 2 - Amostra O55:H7 Ahfq::cat, 3 Amostra O55:H7 $4 h f q:: c a t(p B A D+h f q)$.

\subsubsection{Análise da Proteína EspA}

EspA é uma das mais bem estudadas proteínas relacionadas à lesão $A / E$ devido a sua importância na translocação de efetores e sua expressão foi avaliada na amostra mutante. Quando analisado o perfil proteico total e o perfil proteico secretado (figura 24), é possivel notar que não há reatividade do soro com a proteína EspA na amostra mutante, indicando que a sua produção é muito baixa. Esse dado corrobora com a diminuição da formação da lesão apresentado pela amostra mutante no teste de FAS (figura 24). 


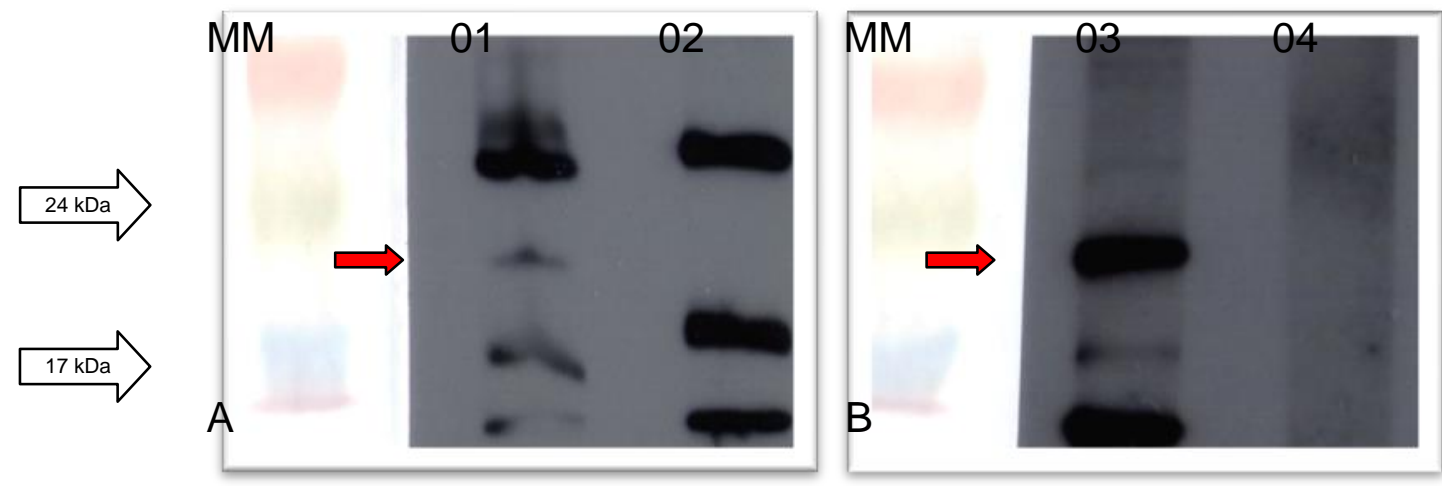

Figura 24 - Reatividade do soro anti-espA contra as proteínas totais (A) e secretadas (B). MM marcador de massa molecular Protein mixture (GE Healthcare); 1 - Amostra O127:H6, 2 - Amostra 0127:H6 $\Delta h f q:: c a t$. As setas indicam a proteína EspA (22 KDa) detectada no immunoblotting.

\subsubsection{Motilidade}

A adesão não é um processo que depende exclusivamente de LEE. Adesinas fimbriais e flagelo fazem parte deste processo. Os testes de motilidade (Figuras 25 e 26) foram realizados a fim de demonstrar a participação de Hfq na regulação flagelar. As amostras selvagens e complementadas apresentaram um padrão de motilidade semelhante, enquanto as amostras mutantes apresentaram uma menor motilidade quando comparada às amostra selvagens. 


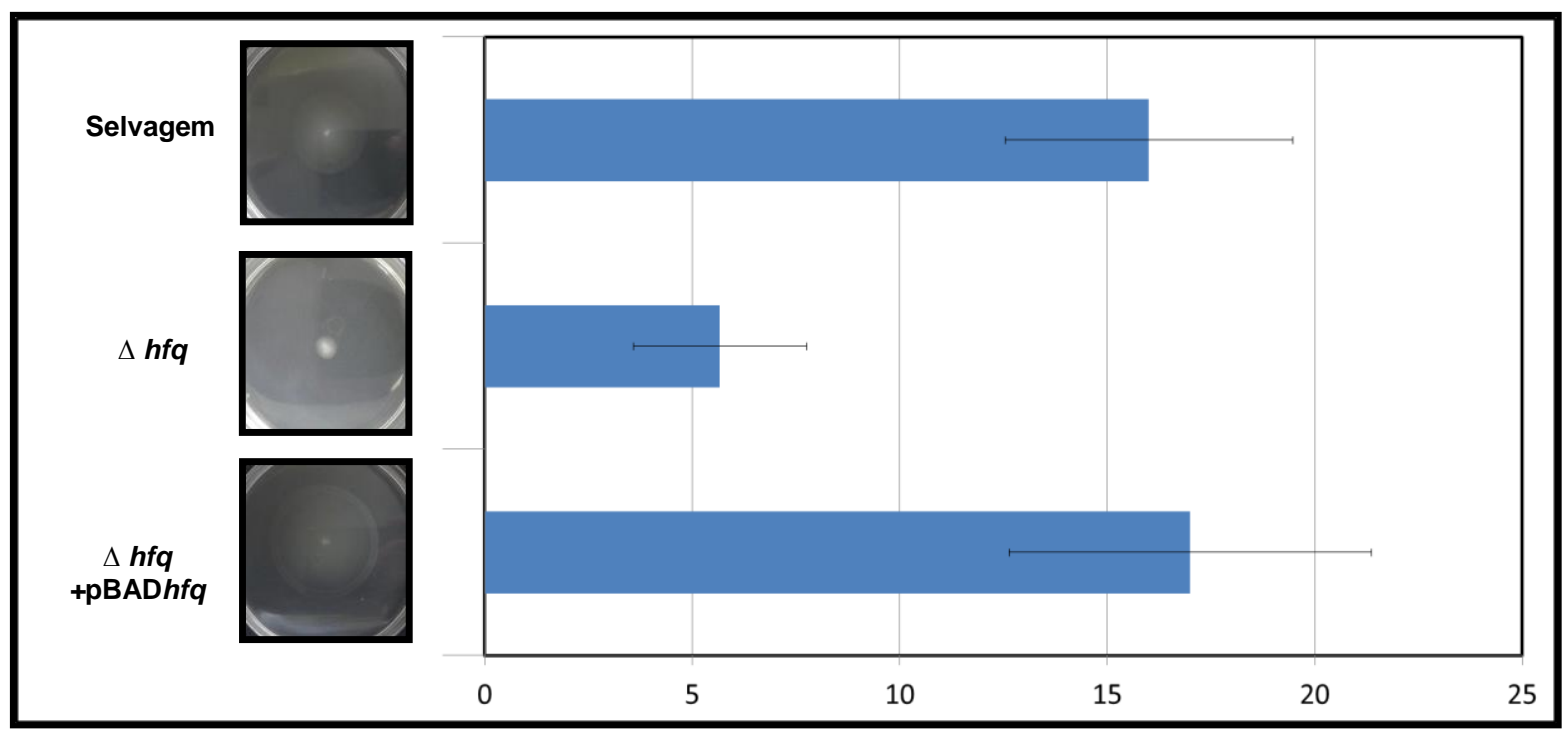

Figura 25 - Ensaio de motilidade em placas de Petri contendo 0,3\% de ágar bacteriológico, 1\% de triptona e $0,25 \%$ de $\mathrm{NaCl}$, incubadas por 8 horas a $37^{\circ} \mathrm{C}$. Os halos representam a capacidade de

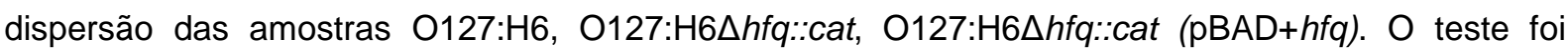
realizado em triplicata e as barras indicam o desvio padrão.

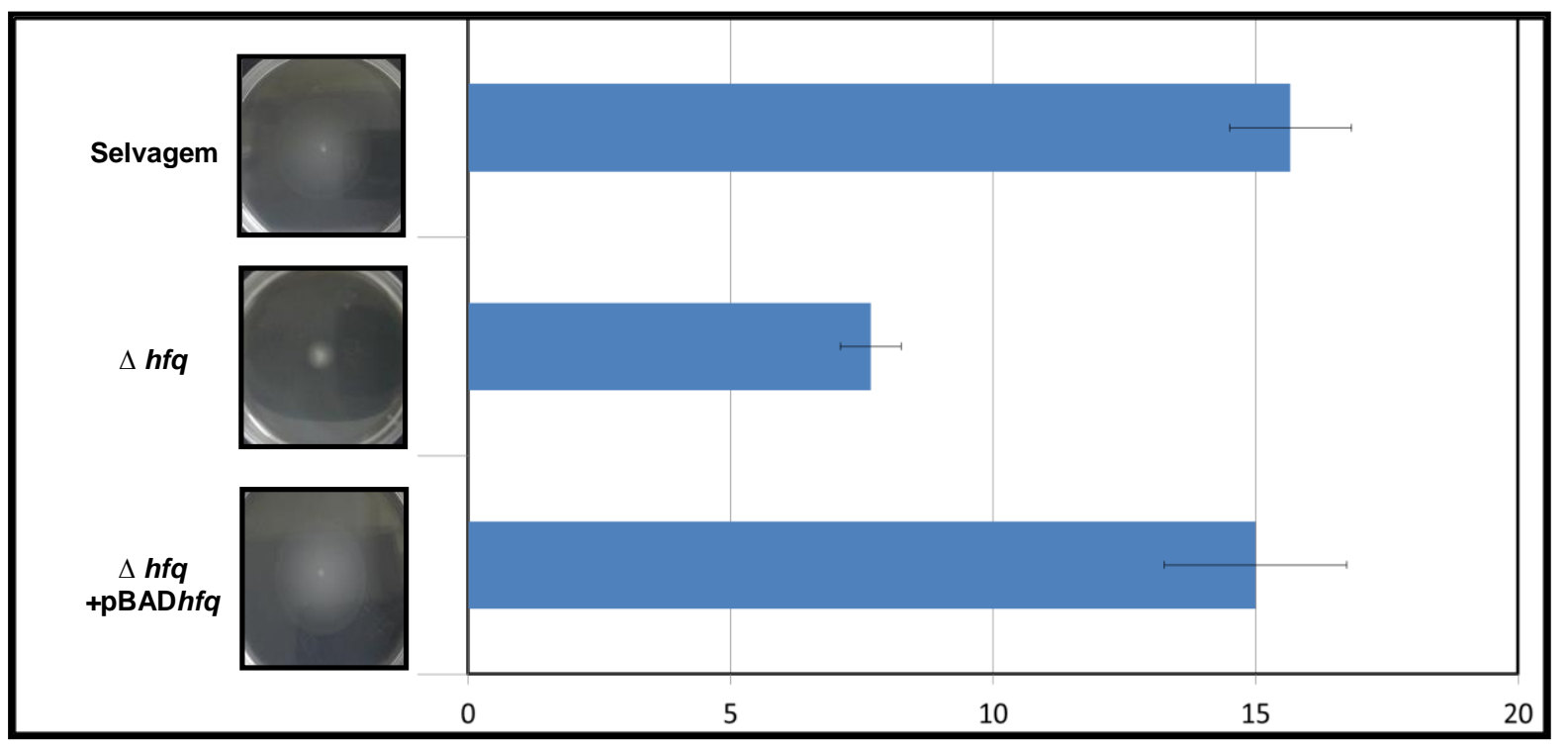

Figura 26 - Ensaio de motilidade em placas de Petri contendo 0,3\% de ágar bacteriológico, 1\% de triptona e $0,25 \%$ de $\mathrm{NaCl}$, incubadas por 8 horas a $37^{\circ} \mathrm{C}$. Os halos representam a capacidade de

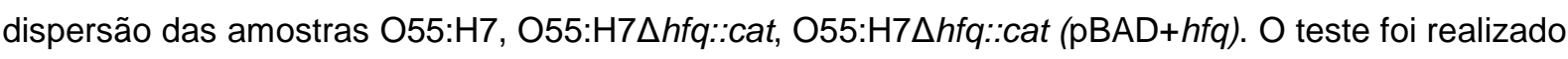
em triplicata e as barras indicam o desvio padrão. 


\subsubsection{Análise Transcricional}

Para a análise transcricional em tempo real, foram escolhidos genes relacionados com a lesão $\mathrm{A} / \mathrm{E}$ : ler (regulador transcricional da região $\mathrm{LEE}$ ), espA (codifica a proteína EspA, do Sistema de Secreção do Tipo III) e eae (adesina intimina); e o gene fliC (principal proteína do flagelo, flagelina). A importância de Hfq na transcrição desses genes foi analisada comparando o nível de transcrição da amostra selvagem com os mutantes. Na figura 27 estão representados os níveis de transcrição dos genes ler, espA e eae da amostra selvagem e mutante do sorotipo O127:H6. Ocorreu um aumento na transcrição do gene ler na amostra mutante, porém não significativo. Entretanto, a transcrição de espA e eae foram nulas. Em relação as amostras do sorotipo O55: $\mathrm{H} 7$, selvagem e mutante, o aumento de ler na amostra mutante foi de 1 vez em relação à amostra selvagem; a diminuição de espA foi de 1,62 vezes e eae foi nula (figura 28). Esses dados corroboram com a diminuição no processo de formação da lesão A/E (figuras 20 e 21), permitindo pressupor que a regulação por Hfq esteja acontecendo em ler, uma vez que a sua transcrição não foi diminuída. 

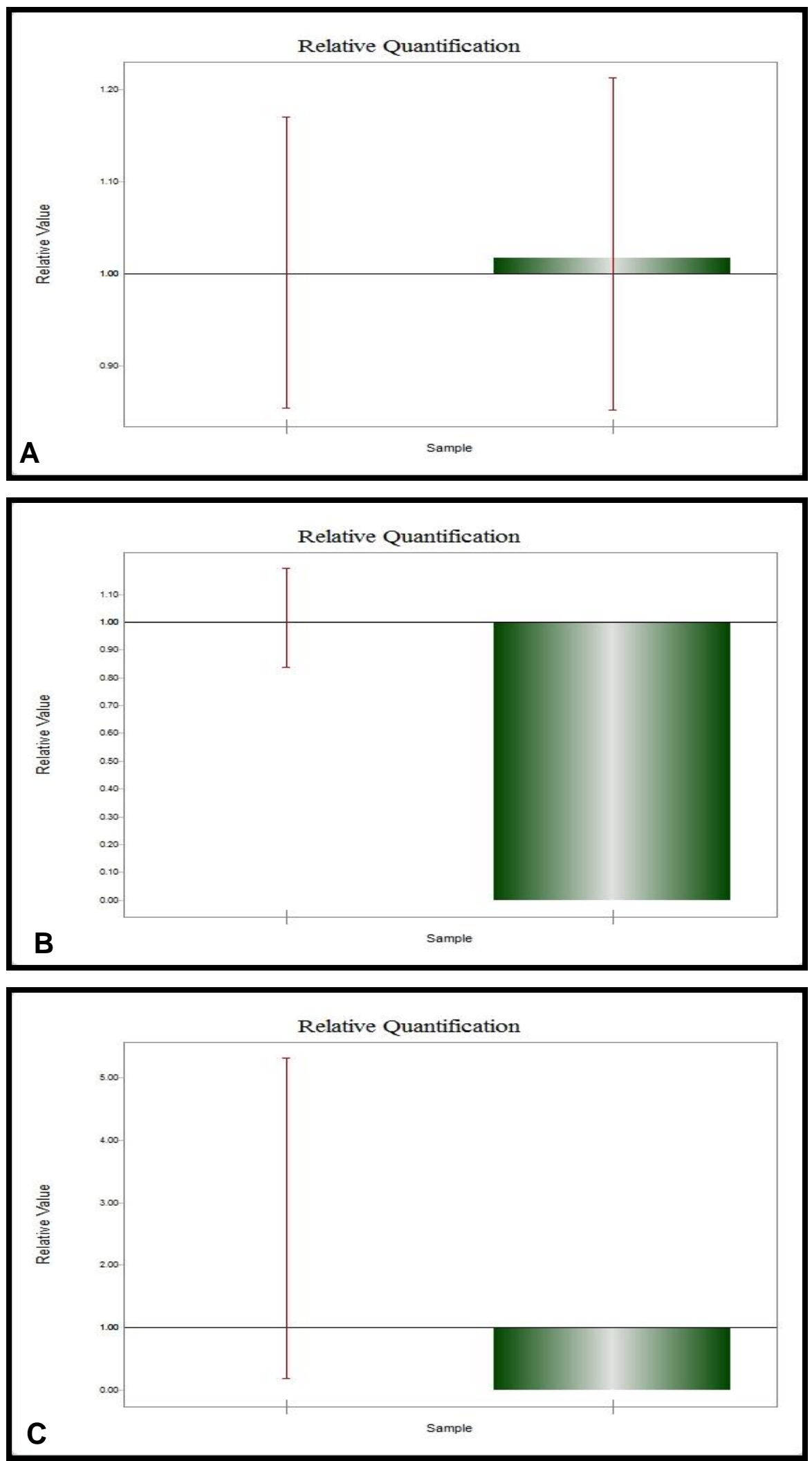

Figura 27 - Análise da transcrição dos genes: $\operatorname{ler}(\mathrm{A})$, espA (B) e eae (C) por qRT-PCR nas linhagens 0127:H6 e 0127:H6Ahfq::cat. Os níveis transcricionais dos genes foram quantificados como diferenças normalizadas com os níveis transcricionais selvagens. Os níveis transcricionais de rpoA foram utilizados como controle interno para normalizar os valores de $C_{t}$. $O$ teste foi realizado em triplicata e as barras indicam o desvio padrão. 

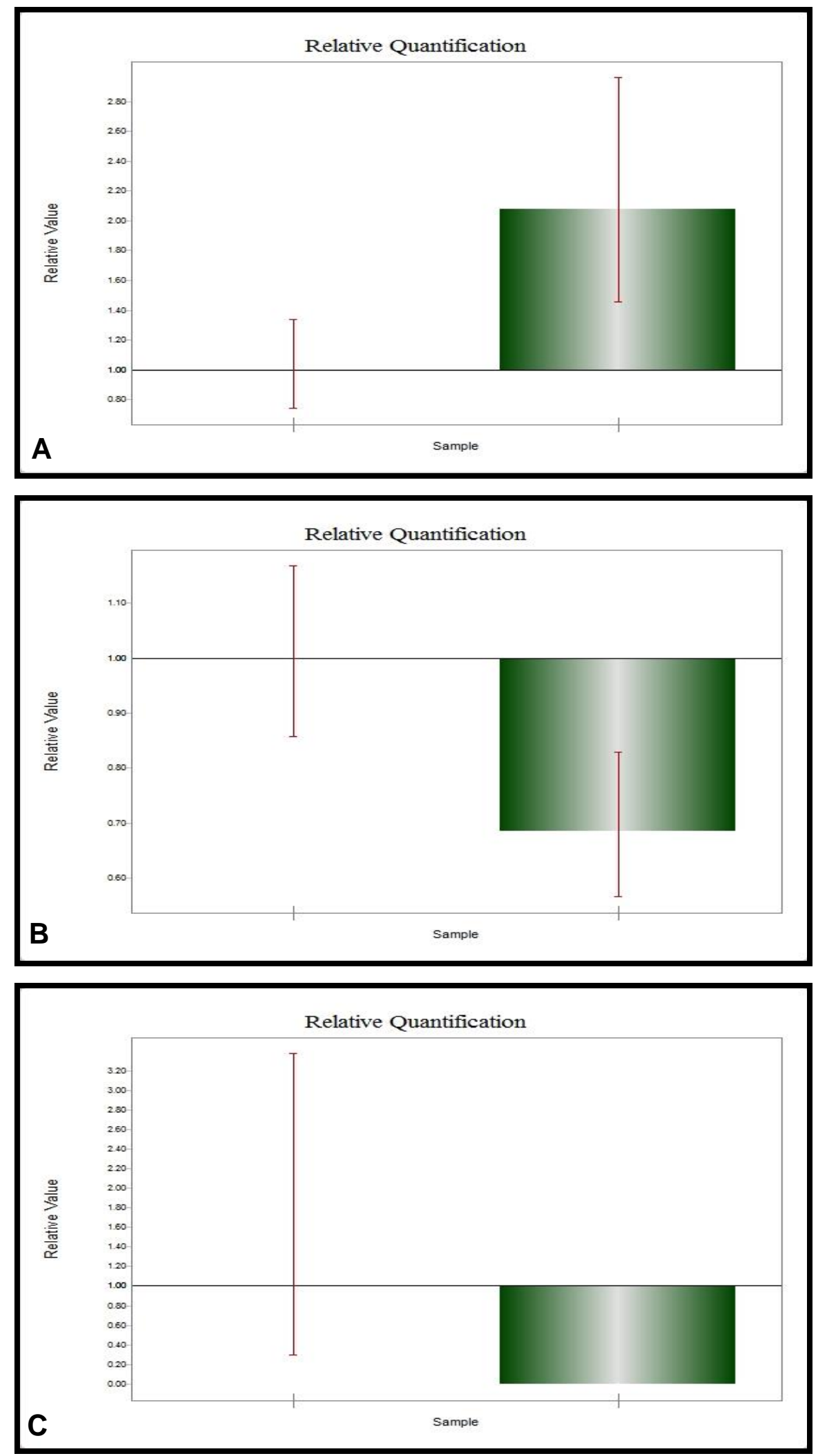

Figura 28 - Análise da transcrição dos genes: ler (A), espA (B) e eae (C) por qRT-PCR nas linhagens O55:H7 e O55:H7Ahfq::cat. Os níveis transcricionais dos genes foram quantificados como diferenças normalizadas com os níveis transcricionais selvagens. Os níveis transcricionais de rpoA foram utilizados como controle interno para normalizar os valores de $C_{t} . \mathrm{O}$ teste foi realizado em triplicata e as barras indicam o desvio padrão. 
A análise da transcrição do flagelo demonstrou uma diminuição de 50 vezes na amostra mutante do sorotipo $\mathrm{O} 55: \mathrm{H} 7$, mais uma vez, corroborando com os dados apresentados no teste de motilidade. Com relação às amostras do sorotipo 0127:H6, não foi possível realizar o teste. A partir de uma análise pelo programa Blast (disponível em: http://www.ncbi.nlm.nih.gov/blast/Blast.cgi), das sequencias de fliC depositados no GenBank, foi confeccionado um par de iniciadores que anelasse com as regiões conservadas do flagelo das amostras 0127:H6 e O55:H7. Entretanto, diversas tentativas na padronização deste foram realizadas sem êxito. Em função disso, optou-se pela utilização do iniciador fliC padronizado por Habdas et al. (2010), porém, resultando apenas na amplificação de amostras que possuem o antígeno flagelar $\mathrm{H} 7$.

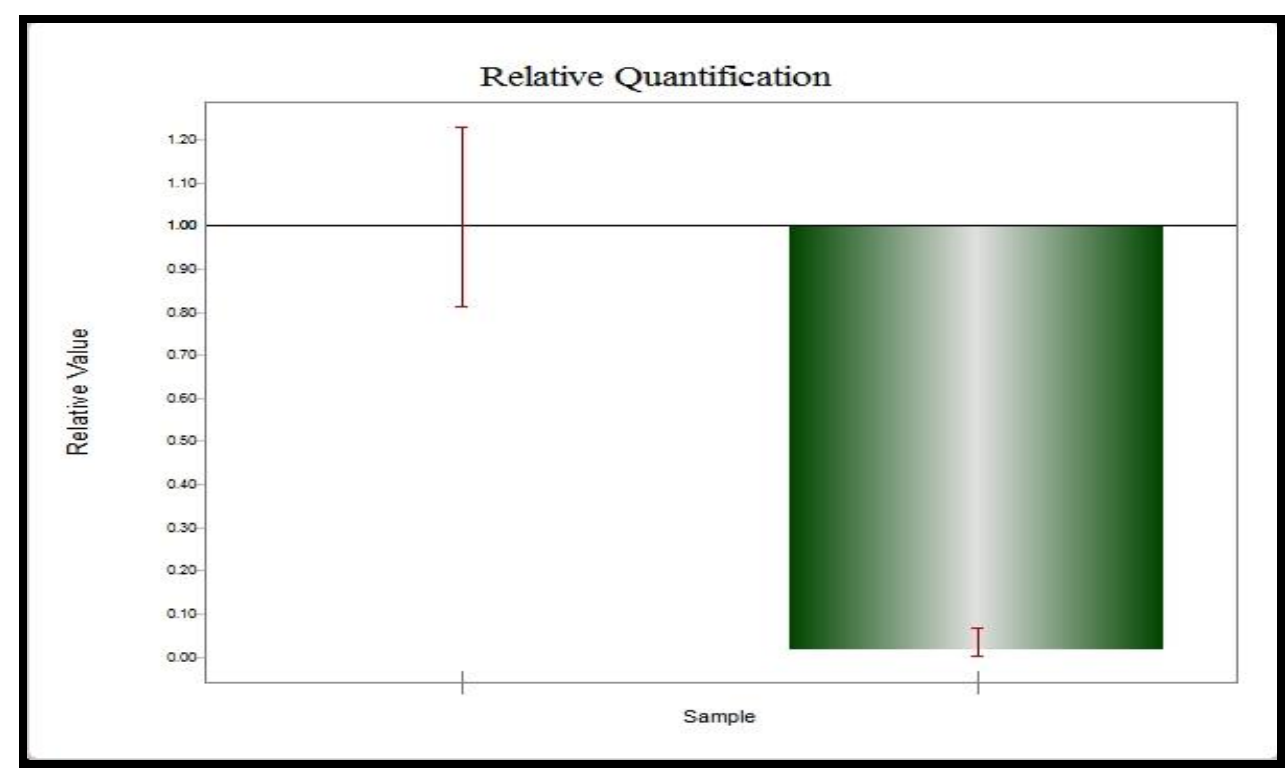

Figura 29 - Análise da transcrição do gene fliC por qRT-PCR nas linhagens O55:H7 e O55:H7Ahfq::cat. Os níveis transcricionais dos genes foram quantificados como diferenças normalizadas com os níveis transcricionais selvagens. Os níveis transcricionais de rpo $A$ foram utilizados como controle interno para normalizar os valores de $C_{t}$. O teste foi realizado em triplicata e as barras indicam o desvio padrão. 
Cabe salientar que os gráficos apresentados referentes aos perfis de transcrição foram gerados pelo programa LineGene 9600, de forma que os valores do eixo " $x$ " não puderam ser modificados. Para realizar uma análise mais didática, os dados referentes às médias geradas, foram inseridos em um novo gráfico (Figura 30). Os valores representados nas amostras selvagens são considerados " 1 " e, assim, cada variante dos genes analisados nas amostras mutantes serão em relação a esse valor.
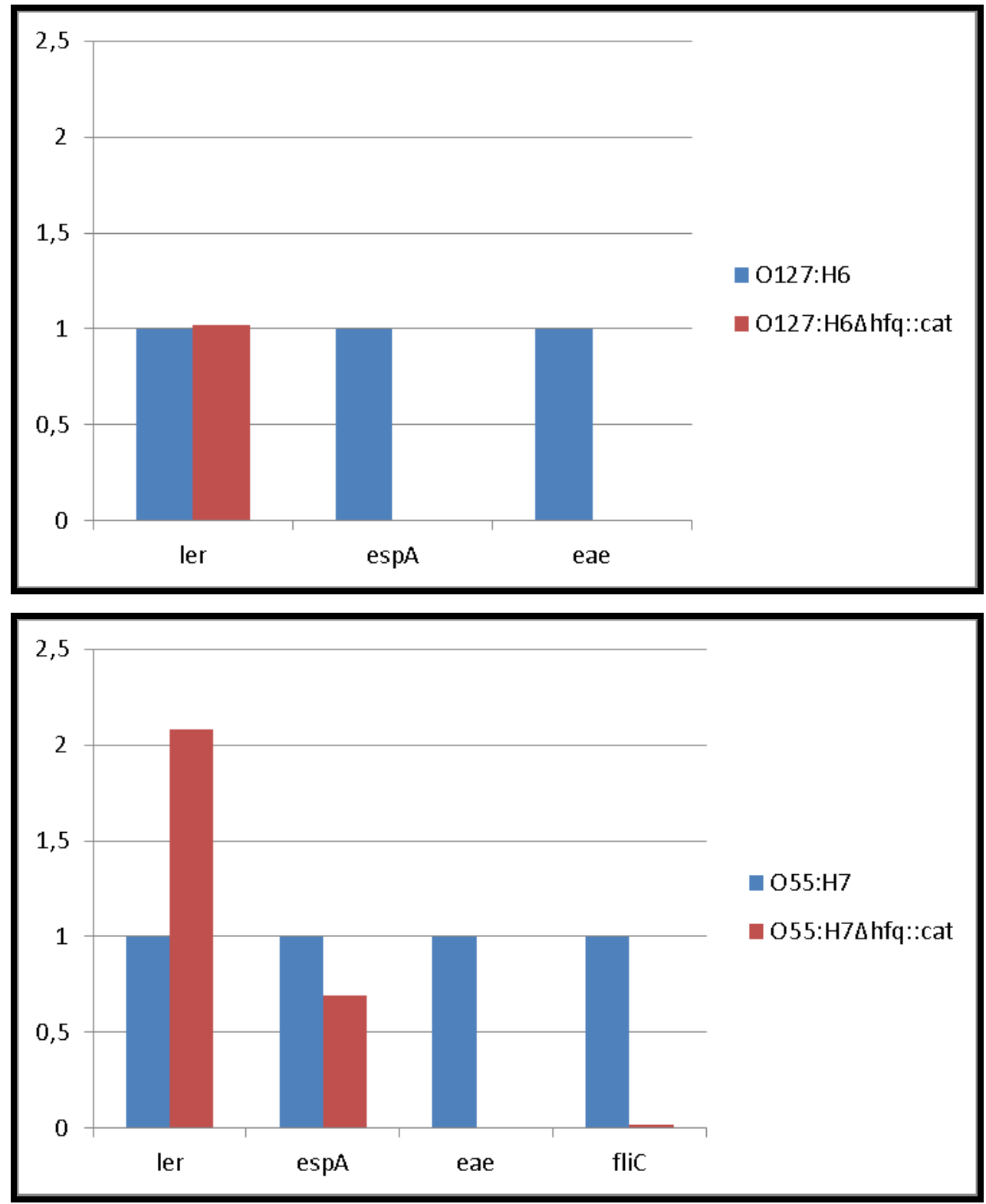

Figura 30 - Análise transcricional gerada a partir dos dados de qRT-PCR. Os valores representam a média de cada triplicata. 


\subsection{Perfil de sRNA}

Uma das funções de Hfq descritas na literatura, é a de proteger os sRNAs de degradação. Com base nesta informação, uma análise semi-qualitativa do perfil dos sRNAs das amostras 0127:H6 e 055:H7, e seus respectivos mutantes

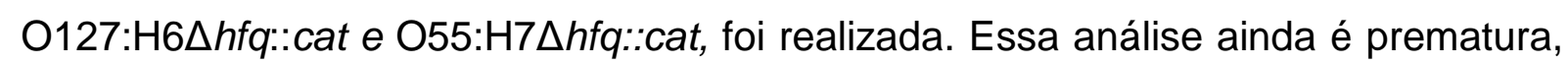
mesmo após várias tentativas de padronização da eletroforese. Entretanto, é possível visualizar a ausência de um sRNA de na amostra selvagem 0127:H6 (figura 31).

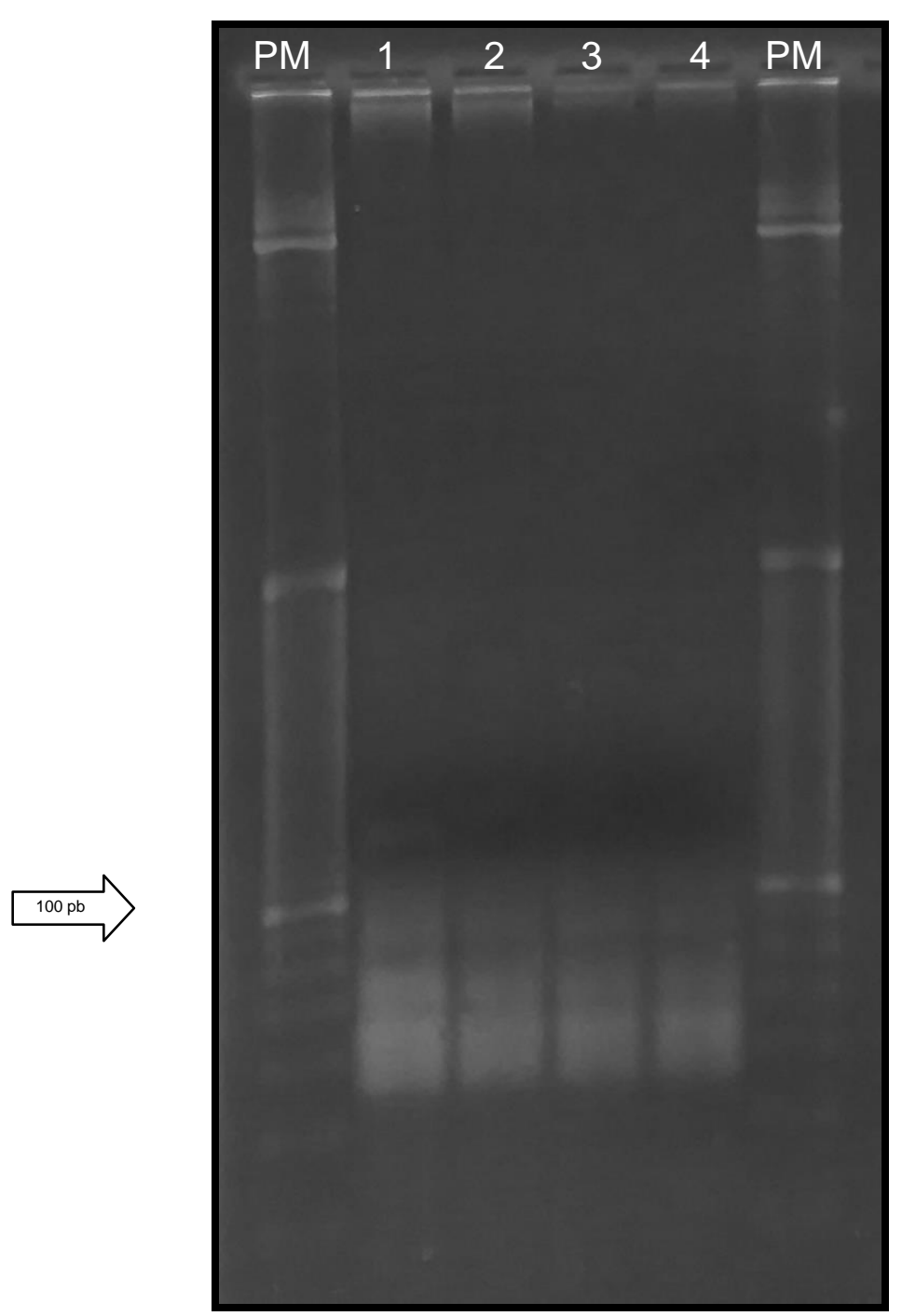

Figura 31 - Eletroforese em gel de poliacrilamida 15\% em condição desnaturante. PM 100 pb DNA

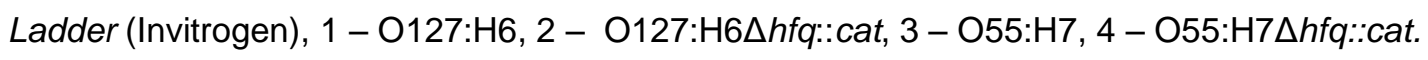




\subsection{Análise in silico do mRNA ler}

A análise transcricional em tempo real nos permitiu pressupor que a regulação da região LEE, e por consequência da lesão $A / E$, está ocorrendo em nível pós transcricional em ler. Hfq, quando associado a sRNAs, pode desbloquear o sítio de ligação do ribossomo para que o mRNA seja traduzido. Uma análise in silico do mRNA de ler revelou que o mesmo se dobra, ocultando o sítio de ligação do ribossomo e, assim, impedindo sua tradução (figura 32). Isso levaria a uma diminuição nos níveis transcricionais dos demais genes regulados por ler.

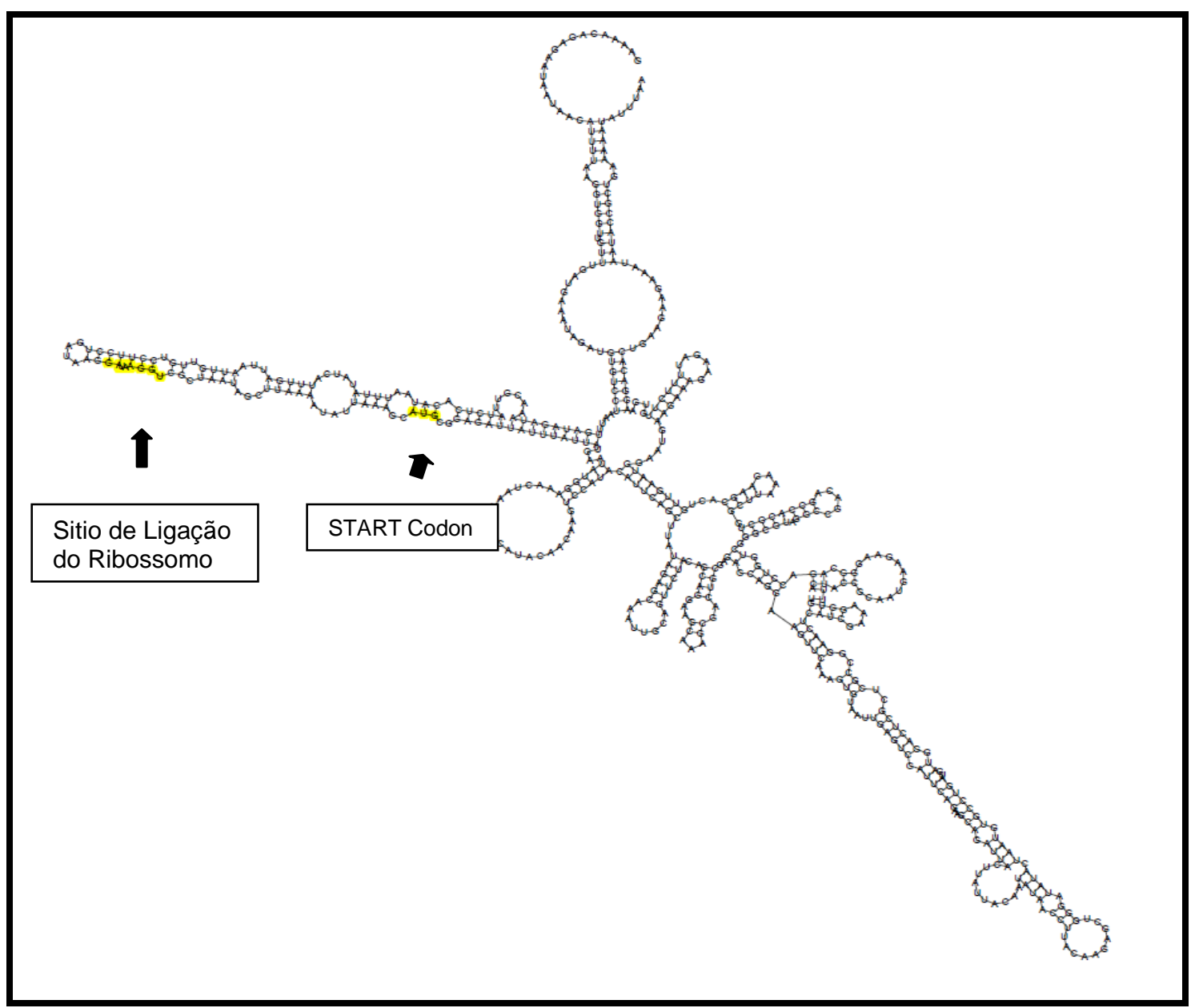

Figura 32 - Análise in silico do RNA mensageiro de ler feita on line no RNAfold Web Server (http://rna.tbi.univie.ac.at/cgi-bin/RNAfold.cgi). 


\section{DISCUSSÃO}

Escherichia coli Enteropatogênica compreende um grupo de patógenos de grande importância e um dos mais bem estudados. Sua patogenicidade está relacionada com a capacidade de causar a lesão histopatológica denominada attaching and effacing. Os genes necessários para conferir esse fenótipo, estão contidos em uma ilha de patogenicidade, denominada LEE. O fato de LEE estar ausente em linhagens comensais e conferir potencial patogênico a uma linhagem K12 transformada, comprova sua participação na patogenicidade de EPEC (McDANIEL; KAPER, 1997).

A região LEE é altamente regulada e codifica o sistema de secreção do tipo III, capaz de translocar proteínas e efetores para o interior da célula hospedeira. Diversas proteínas reguladoras, bem como fatores ambientais atuam sobre LEE. Os principais fatores regulatórios são: perABC, membro da família AraC de reguladores transcricionais, que atuam em LEE nas amostras de EPEC típica (MELLIES et al., 1999); Ler, proteína da família H-NS, que atua competindo com as proteínas globais regulatórias H-NS pelos promotores de LEE (BARBA et al., 2005); GrIA/R, complexo regulatório inserido em LEE, que através do feedback entre GrIA (Ativador) e GrIR (Repressor), atuam sobre LEE1 e, consequentemente, sobre ler (IYODA et al., 2006); a proteína Fis está envolvida na regulação de ler e LEE4 (GOLDBERG et al., 2001); as proteínas BipA e CsrA atuam positivamente sobre a regulação de ler (BHATT et al., 2009; GRANT et al., 2003). Além desses fatores, os sistemas de Quorum Sensing luxS/Al-2 e Al-3 foram associados à regulação dos genes relacionados à lesão attaching and effacing em amostras de Escherichia coli Enterohemorrágica e Enteropatogênica (FRANZIN, 2013; SIRCILI et al., 2004; SPERANDIO et al., 2002; SPERANDIO et al., 2007).

Recentemente, a proteína Hfq foi descrita como um regulador transcricional de LEE em amostras de Escherichia coli Enterohemorrágica do sorotipo O157:H7 (HANSEN; KAPER, 2009; KENDALL et al., 2011; SHAKHNOVICH; DAVIS; WALDOR, 2009). A regulação por Hfq ocorre quando a proteína está associada à moléculas de sRNA. Codificados a partir de regiões intergênicas, os sRNAs regulam a expressão gênica pareando-se com o mRNA alvo (VECEREK et al., 2010). Os sRNAs podem aumentar a dinâmica das respostas celulares por serem produzidos mais rapidamente do que proteínas e possuírem uma meia-vida curta, permitindo 
que sua ação seja interrompida de forma imediata (MIKA; HENGGE, 2014). Alguns sRNAs participam da regulação basal de manutenção da célula, outros são altamente induzidos quando a célula encontra-se em condições de estresse, como alta osmolaridade, perturbação do envelope celular, estresse oxidativo ou carência nutricional, sugerindo sua contribuição no controle de seus alvos sob condições específicas (PAPENFORT; VOGEL, 2010).

Com o intuito de compreender a regulação da expressão dos fatores envolvidos na patogenicidade de EPEC, foi investigado o papel desempenhado pela chaperona $\mathrm{Hfq}$ in vitro. Para tal observação, a primeira etapa deste trabalho consistiu na mutação do gene hfq das amostras 0127:H6 e 055:H7 (figuras 11 a 14), aplicando a metodologia descrita por Datsenko e Wanner (2000), empregada por diversos autores (BERDICHEVSKY et al., 2005; BUSTAMANTE et al., 2011; HANSEN; KAPER, 2009; IYODA et al., 2006; KENDALL et al., 2011; KULESUS et al., 2008; SHAO; BASSLER, 2012), que consiste na recombinação homóloga utilizando as proteínas do fago lambda.

Uma das funções descritas para Hfq é a proteção do sRNA da degradação por exonucleases (VOGEL; LUISI, 2011). Com base nesse dado, foi realizada uma análise comparativa do perfil de sRNAs das amostras selvagens e deletadas em $h f q$. Na figura 21, é possível observar a ausência de um possível sRNA na amostra 0127:H6 $\Delta h f q:: c a t$ quando comparada com a amostra selvagem. Essa análise é semi-qualitativa e meramente ilustrativa, sendo realizada apenas como padronização para futuros testes.

Para confirmar os efeitos da mutação, bem como a complementação do gene $h f q$, foi realizada uma análise da transcrição do gene $h f q$. Os resultados indicam a ausência do mRNA correspondente nas amostras mutantes e a presença nas amostras selvagens e complementadas (figura 15). Isso é indicativo de que os efeitos fenotípicos observados nos diversos ensaios realizados com os mutantes são decorrentes da ausência de Hfq, assim como nas amostras complementadas é efeito da restauração in trans do gene $h f q$.

Uma vez realizada e confirmada a mutação e complementação, foram iniciados os testes fenótipos. Primeiramente foi realizado o teste de adesão, que auxilia na categorização de amostras de Escherichia coli Diarreiogênicas (NATARO; KAPER, 1998). Amostras de EPEC típica apresentam o padrão de adesão localizado, enquanto amostras de EPEC atípica podem apresentar os padrões 
localizado-like, agregativo e difuso (TRABULSI; KELLER; GOMES, 2002). As amostras deste estudo 0127:H6 (EPEC típica) e O55:H7 (EPEC atípica) apresentam o padrão localizado e localizado-like, respectivamente. Como pode ser observado nas figuras 18 e 19, as amostras deficientes em hfq apresentaram uma diminuição no número de bactérias aderidas, além da alteração do seu padrão de adesão. As amostras complementadas tiveram seu fenótipo restaurado. A diminuição da adesão não está relacionada com a diminuição da taxa de crescimento da amostra mutante, uma vez que a curva de crescimento não apresentou diferença entre a taxa de crescimento das amostras selvagens, mutantes e complementadas (figuras 16 e 17). Já foi demonstrado que amostras mutantes em hfq de Klebsiella pneumoniae (CHIANG et al., 2011) e Salmonella Typhimurium (SITTKA et al., 2007) não apresentaram alterações no metabolismo e tão pouco na taxa de crescimento, o que corrobora os dados obtidos com EPEC.

A capacidade de induzir o acúmulo de actina polimerizada no local da adesão bacteriana, característico da lesão $A / E$, foi avaliada. Knutton et al. (1989) estabeleceu o teste de FAS como indicativo deste fenótipo. As amostras foram analisadas após 6 horas de interação à monocamadas de células HeLa, possibilitando verificar a formação de pedestais pelas amostras 0127:H6 e 055:H7 (figuras 20 e 21). A amostra 0127:H6 $h f q:: c a t$ apresentou um número muito menor de pedestais em comparação à amostra selvagem. Com relação à amostra 055:H7 $\Delta h f q:: c a t$, a diminuição no número de pedestais foi muito mais evidente. $\mathrm{O}$ fenótipo foi restaurado nas amostras complementadas com gene hfq. Esse fato já foi observado em amostras de E. coli mutadas em hfq (KENDALL et al., 2011).

A participação de Hfq ocorre na regulação pós transcricional associada à moléculas de sRNA codificadas em trans. Essa regulação pode levar ao bloqueio ou a tradução de alguns mRNA. Desta forma, foi analisado o perfil proteico das amostras em estudo em géis de poliacrilamida nas concentrações de $8 \%, 12 \%$ e $18 \%$. Independente da concentração do gel, foi possível avaliar maior concentração de algumas proteínas, bem como a diminuição de outras, nos mutantes hfq de ambos os sorotipos. Nas figuras 22 e 23 estão apresentados os resultados obtidos em géis de acrilamida a $12 \%$. Esse fenômeno já foi observado em diversas espécies bacterianas.

Vogt e Raivio (2014), analisando o perfil de OMPs de amostras de EPEC mutantes em $h f q$, descreveram um aumento relativo das proteínas OmpA, OmpC e 
OmpF. Esse aumento está associado à maior atividade do fator $\sigma^{\mathrm{E}}$, relacionado ao estresse proteico de membrana externa e do espaço periplasmatico. Sabe-se ainda, que o sRNA MicA atua negativamente na tradução do gene ompA de amostras de $E$. coli (HENDERSON et al., 2013).

Amostras de Salmonella Typhimurium mutadas no gene $h f q$, ao serem analisadas em eletroforese bi-dimensional, demonstraram o acúmulo de $\mathrm{OmpD}$, uma porina específica de Salmonella, e a diminuição drástica da proteina flagelar FliC (SITTKA et al., 2007).

O sRNA McaS é responsável por aumentar a transcrição do regulador do flagelo flhD e reprimir a transcrição da fimbria curli, atuando na região 5'UTR do seu regulador csgD (THOMASON et al., 2012). McaS ainda é proposto como um sRNA auxiliar na transição da fase séssil para planctônica durante o processo de formação do biofilme. A análise de proteínas extracitoplasmáticas em amostras de Klebsiella pneumoniae mutadas em $h f q$, evidenciou que 32 apresentaram tradução aumentada e 10 apresentaram tradução diminuida (CHIANG et al., 2011).

As análises transcricionais em tempo real foram realizadas para avaliar 0 efeito da mutação em $h f q$ na transcrição dos genes envolvidos na patogenicidade das amostras de EPEC, e também corroborar a deficiência observada na formação da lesão $A / E$ nas amostras mutantes. Essa análise permitiu pressupor em que nível a transcrição seria afetada. Inicialmente, foi avaliada a transcrição do gene ler, regulador global de LEE. As amostras 0127:H6 e 0127:H6 $4 h f q:: c a t$ não tiveram alteração quanto à transcrição deste gene (figura 27a). Em seguida, foi realizada a análise do gene espA, proteína necessária para a formação da estrutura em forma de "agulha" do sistema de secreção do tipo III, pela qual os efetores são translocados para o interior da célula hospedeira durante a lesão A/E. Uma vez que não houve alteração no nível de transcrição de ler, era esperado que o nível de transcrição de espA também se mantivesse. Entretanto, a quantidade de mRNA de espA mensurada foi menor nas amostras mutantes, quando comparado com as amostras selvagens (figura 27b). Este perfil se manteve na análise do mRNA de eae (adesina responsável pela aderência intima da bactéria ao epitélio intestinal) (figura 27c). Com base nesses resultados, pressupõe-se que a regulação por Hfq esteja ocorrendo no nível pós transcricional de ler. A diminuição da transcrição dos genes analisados da região LEE corroboram os dados obtidos no teste de FAS. Kendall et al. (2011) descreveram que mutantes em hfq tiveram a transcrição dos genes de 
LEE alterada nas amostras de EHEC do sorotipo O157:H7 (86-24). Em amostras de Salmonella Typhimurium, mutantes em hfq foram deficientes na secreção de diversos efetores da ilha de patogenicidade SPI-1 (SITTKA et al., 2007).

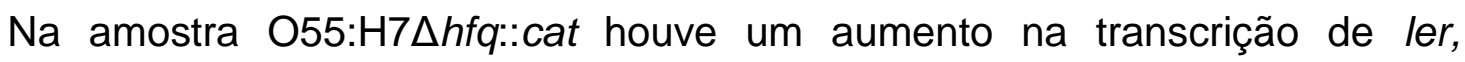
quando comparado com a amostra selvagem (figura 28a). Esse resultado indica que a mutação em $h f q$ alterou a transcrição de genes responsáveis pela regulação de ler. O aumento da transcrição de ler em mutantes hfq já tinha sido relatado por dois grupos de pesquisa: Shakhnovich, Davis e Waldor (2009), demonstraram o acúmulo de Ler nas amostras EDL933 (EHEC pertencente ao sorotipo 0157:H7); e Hansen \& Kaper (2009) relatam que na amostra EDL933 a mutação em hfq altera os níveis de GrlA. Um aumento de GrlA, antecipa a transcrição do gene ler e, consequentemente, de LEE, levando à antecipação da lesão A/E. lyoda et al. (2006), ao analisarem mutantes em grlR da amostra de EHEC Sakai, constataram a super expressão dos genes de LEE. Ao analisar os níveis de espA na amostra 055:H7 $h f q:: c a t$, foi observada uma diminuição na transcrição com relação à amostra selvagem (figura 28b). O mRNA do gene eae, se comportou da mesma maneira que na amostra de EPEC típica e apresentou uma redução da transcrição na amostra mutante em relação à selvagem (figura $28 \mathrm{c}$ ).

É importante ressaltar que, apesar da transcrição de ler não ter diminuído na amostra mutante 055:H7 $\Delta$ hq::cat, não foi possível observar a formação da lesão $\mathrm{A} / \mathrm{E}$. Isso pode ser explicado pelo fato de os demais genes da região LEE analisados (espA e eae) apresentarem diminuição da transcrição. Além disso, as amostras de EPEC atípica apresentam um atraso na formação da lesão $A / E$, com relação à amostras de EPEC típica. Isso ocorre, dentre outros fatores, pela ausência do operon perABC nessas amostras (BUERIS, 2008).

Ler desempenha um papel importante na regulação de LEE, competindo com as proteínas H-NS globais pela disponibilidade das regiões promotoras dos operons. A transcrição de ler está presente nos estágios iniciais do contato bacteriano com o epitélio intestinal. Yerushalmi et al. (2014), avaliaram que nos primeiros $10 \mathrm{~min}$ de interação já é possível detectar o mRNA Ler, sendo que os demais genes tiveram sua transcrição iniciada após 70 min e o tempo necessário para que o sistema de secreção do tipo III fosse funcional foi de $100 \mathrm{~min}$. Esse início precoce favorece o acúmulo de Ler no interior da célula bacteriana, favorecendo a transcrição dos demais genes de LEE. Entretanto, ler é capaz de se autoregular, quando atinge a 
concentração necessária para a ativação dos demais genes de LEE e para prevenir uma superprodução, indicando que as bactérias produzem somente o necessário para o sucesso da colonização (BERDICHEVSKY et al., 2005). Essa regulação estrita de ler, e consequentemente de LEE, reforça a dependência de Ler para o sucesso da colonização e da lesão A/E.

No intuito de confirmar os resultados transcricionais de espA, foi realizado um ensaio para avaliar a expressão e secreção da proteína EspA, que faz parte do aparato de secreção do tipo III. Foi possível observar através de immunoblotting a ausência da proteína na amostra mutante O127:H6, tanto no sedimento quanto na fração secretada (figura 24). Esse dado corrobora a ausência de mRNA observado no PCR em tempo real. Não houve reatividade do soro anti-EspA com a amostra O55:H7 e O55:H7 $h f q:: c a t$.

Foi demonstrado por Abe et al. (1998), utilizando mutantes não polares no gene espA de REPEC (Rabbit EPEC), que a lesão attaching and effacing é dependente de EspA, reforçando a necessidade dessa proteína na translocação de Tir (Translocated Intimin Recepetor) para o interior da célula hospedeira. Além disso, teste utilizando soros policlonal anti EspA produzidos em coelho, demonstraram redução da lesão A/E produzidas por amostras de EHEC (LA RAGIONE et al., 2005)

A importância de EspA nos estágios iniciais da adesão podem pressupor seu papel como adesina. Clearly et al. (2004), destacam a importância de Bfp e EspA para o processo de colonização. Bfp (bundle-forming pilus) é uma fimbria do tipo IV e os genes responsáveis pela sua biogênese estão contidos no plasmídeo EAF das EPEC típicas. A ausência de Bfp pode ser um dos indícios do atraso na formação da lesão A/E por EPEC atípica.

A presença e a funcionalidade do flagelo foi analisada nas amostras deste estudo, uma vez que o flagelo é um fator importante para a colonização do hospedeiro. A análise por PCR em tempo real do gene fliC, responsável por codificar a proteína flagelina do filamento flagelar, permitiu evidenciar a diminuição de 50 vezes da transcrição do mRNA da amostra mutante 055:H7 4 fq::cat quando comparada com a amostra selvagem O55:H7 (figura 29). Essa análise não foi possível de ser realizada nas amostras do sorotipo 0127:H6, devido à dificuldade na padronização dos iniciadores capazes de anelar com o gene fliC do antígeno flagelar H6. Entretanto, ao realizar uma análise em agar semi sólido, foi possível evidenciar uma diminuição da motilidade das amostras mutantes (O127:H6 $\Delta$ hfq::cat e O55:H7 
$\Delta h f q::$ cat) quando comparadas com as amostras selvagens e complementadas com o gene $h f q$ in trans (figuras 25 e 26). Em amostras do sorotipo 0127:H6 o flagelo está presente no estágio inicial da adesão e aquelas que estão aderidas no pedestal de actina, não apresentam mais o flagelo (IYODA et al., 2006).

A síntese flagelar está relacionada com a presença de sRNAs e, consequentemente, com a presença de Hfq (DE LAY; GOTTESMAN, 2012; KULESUS et al., 2008; MIKA; HENGGE, 2013; SUDO et al., 2014; THOMASON et al., 2012). Seis sRNAs estão associados com a diminuição da tradução falgelar, são eles: OmrA, ArcZ, OxyS, SdsR, OmrB e GadY e atuam no pareamento direto na região 5'UTR do operon flhDC. Além disso, outros dois sRNAs, o MicA e o McaS, favorecem a motilidade em amostras de Escherichia coli (DE LAY; GOTTESMAN, 2012). MicA participa da regulação da motilidade em outra etapa ainda desconhecida, diferente de McaS, que atua diretamente em flhD. Os mesmos autores ainda demonstram que os sRNAs ArcZ e McaS realizam o pareamento em flhD na mesma região do RNA mensageiro. O operon flhDC está no topo da hierarquia flagelar, responsável pela regulação da transcrição do operon de classe II flagelar, que contém entre outros o fator $\sigma^{28}$ ou $\sigma^{\mathrm{F}}$. Este, por sua vez, regula o operon de classe III, que contém entre outros os genes motA e fliC (ARNOSTI, 1994; LU; MATSUMARA, 1994). Sudo et al. (2014), descrevem um novo sRNA, que participa da regulação da motilidade em amostras de EHEC e E. coli K12, denominado esr41 ("Enterohemorragic E. coli Small RNA \#41"), que ao ser transformado nestas amostras, foi capaz de aumentar a motilidade.

Devido à similaridade genética entre o sistema de secreção do tipo III e o flagelo, lyoda et al. (2006) realizaram uma análise para avaliar a influência dos reguladores de LEE na regulação da síntese flagelar. Utilizando amostras de EHEC mutantes em $g r l R$, foi verificada uma redução da motilidade. Esse fato sugere uma regulação negativa de GrlA na síntese flagelar, já que a amostra mutada no operon grLAR não apresentou diminuição da motilidade.

Diversos estudos relacionando $\mathrm{Hfq}$ com fatores de virulência foram realizados em amostras de Salmonella Typhimurium, Klebsiella pneumoniae, Vibrio cholerae, Vibrio harveyi, EAEC, UPEC (Escherichia coli Uropatoenênica) e AIEC (Escherichia coli Aderente-Invasiva, isoladas de pacientes com Doença de Crohn), além de EHEC. 
A mutação em hfq nas amostras de Salmonella Typhimurium revelou uma diminuição quanto à capacidade de invadir o epitélio intestinal e alteração da taxa de sobrevivência em macrófagos, utilizando ratos como modelo animal (SITTKA et al., 2007).

Ao realizarem uma análise genética global em amostras de Klebsiella pneumoniae mutantes em hfq, Chiang et al. (2011) observaram um aumento na transcrição de 287 genes, incluindo genes envolvidos com resistência à estresse, virulência, motilidade e secreção.

Amostras mutantes de Vibrio cholerae e Vibrio harveyi, apresentam influência de sRNAs na regulação dos genes que são responsáveis pela formação de biofilme e dos fatores de virulência, principalmente a toxina colérica (BASSLER, 2012; LENZ et al., 2004; TU; BASSLER, 2007; SHAO).

As E. coli causadoras de infecções do trato urinário, as UPEC, foram analisadas quanto à regulação dos fatores de virulência por Hfq. Os mutantes apresentaram atenuação da capacidade de colonizar o trato urinário, motilidade, resistência ao pH ácido e formação de biofilme (KULESUS et al., 2008).

A amostra de EHEC 86-24 (sorotipo 0157:H7) mutante em hfq foi menos aderente, porém a transcrição e a produção da toxina Stx2 foi aumentada, tornando os mutantes em hfq mais virulentos (KENDALL et al., 2011).

Mutantes em $\mathrm{Hfq}$ de amostras de EPEC típica apresentam uma maior expressão de Bfp. Essa chaperona é responsável pela repressão de PerA, que age como um regulador do operon bfp (VOGT; RAIVIO, 2014). Bfp participa do processo de adesão, principalmente mediando a interação entre bactérias e formação de microcolônias, características do padrão de adesão localizada.

Devido à similaridade de algumas vias biológicas, o nematóide Caenorhabditis elegans, tem sido usado como modelo vivo para para estudos envolvendo a patogenicidade bacteriana. Amostras de AIEC (SIMONSEN et al.,2011) e amostras de EHEC, EAEC e UPEC (BOJER et al., 2012) apresentaram redução da mortalidade do $C$. elegans quando mutadas em $h f q$.

Como não houve diferença significativa na transcrição do mRNA de ler nas amostras mutantes, foi realizada uma análise mais aprofundada de seu comportamento estrutural. Em associação, Hfq e sRNAs, podem desempenhar um papel importante na regulação pós transcricional, liberando o sítio de ligação do ribossomo para o início da tradução. A formação de uma estrutura em forma de 
grampo do mRNA impossibilita esse processo. A associação da proteína Hfq ao mRNA impede a formação dessa estrutura.

Com base nos dados de Jeong et al. (2012), foi possível identificar o promotor do gene ler, o sítio de ligação do ribossomo e o códon de iniciação. Foi realizada uma análise in silico utilizando o RNAfold Web Server, que revelou um dobramento que impede o acesso do ribossomo ao sítio de ligação. Esse dobramento apresenta energia livre de -124, $62 \mathrm{kcal} / \mathrm{mol}$, indicando maior probabilidade da estrutura ser formada (figura 32). A participação de Hfq associada à outra molécula de sRNA ainda não descrita, torna-se fundamental para a tradução do mRNA de ler e, consequentemente, a formação da lesão A/E. Recentemente, o RNAfold Web Server foi utilizado para realizar uma análise in silico de um novo sRNA, descrito com esrE (“Essential small RNA Escherichia coli”) (CHEN et al., 2012).

A análise dos dados obtidos neste trabalho permitiu propor um esquema da influência de Hfq na regulação da região LEE e flagelo nas amostras estudadas. De fato, a associação entre o mRNA de ler e um sRNA codificado em trans parece ser necessária. Contrariando os dados obtidos por Kendall et al. (2011), os níveis de transcrição de ler não foram diminuídos, pelo contrário, nas amostras de EPEC atípica foi observado um aumento. Neste caso, o mecanismo regulatório parece agir nos reguladores de ler. Apesar desse aumento na transcrição, as amostras não foram capazes de causar a lesão $A / E$, o que corrobora a necessidade de um sRNA para sua tradução. A possibilidade do dobramento natural do mRNA de ler, ocultando o sítio de ligação do ribossomo, enfatiza a teoria de que a transcrição dos genes da região LEE de Escherichia coli Enteropatogênica típica e atípica necessita da associação entre o sRNA e a chaperona Hfq, para a ocorrência da transcrição e, por consequência, a formação da lesão attaching and effacing.

Estudos tem demonstrado a participação de Hfq na regulação positiva (a favor da tradução) de diversas proteínas em amostras E. coli. Em baixas temperaturas o mRNA de rpoS necessita de Hfq para sua eficiente tradução. Isso ocorre por que o mRNA forma uma estrutura "intra-molecular stem-loop" que sequestra o sítio de ligação do ribossomo. A presença do sRNA DsrA associado com Hfq, permite uma estabilização do mRNA, a clivagem da região 5'UTR e a tradução do fator $\sigma^{S}$ de estresse (VECEREK et al., 2010).

McaS atua como um regulador positivo da transcrição de flhD da mesma maneira que DsrA, desbloqueando o sítio de ligação do ribossomo. Diferente da 
maioria dos sRNAs, a análise in silico indica que o McaS possui a capacidade de se ligar a duas regiões 5'UTR do RNA mensageiro (THOMASSON et al., 2012).

A participação de Hfq nos processos patológicos está descrita em diversos patógenos. Entretanto, até o momento não houve a caracterização de moléculas de sRNA associadas a essa finalidade. O estudo de regulação da expressão gênica em procariotos ganhou uma nova perspectiva a partir da descoberta dos mecanismos de atuação dos sRNAs. A necessidade de realização de pesquisas abordando novas alternativas no tratamento de infecções que não favoreçam a ocorrência de microorganismos resistentes aos antimicrobianos nos leva a buscar o entendimento dos mecanismos de sRNAs para sua utilização na regulação da expressão gênica com finalidades terapêuticas. 


\section{CONCLUSÃO}

As amostras mutantes em hfq de Escherichia coli Enteropatogênica típica (sorotipo O127:H6) e atípica (sorotipo O55:H7) obtidas neste estudo, apresentaram uma redução na capacidade de adesão e formação da lesão attaching and effacing em relação às amostras selvagens.

A análise de transcrição de genes envolvidos na lesão attaching and effacing corroborou os resultados obtidos nos ensaios fenotípicos.

Foi observada uma redução de motilidade das amostras mutantes em $h f q$.

Foi proposto um modelo da participação de Hfq na regulação dos fatores de virulência das amostras estudadas.

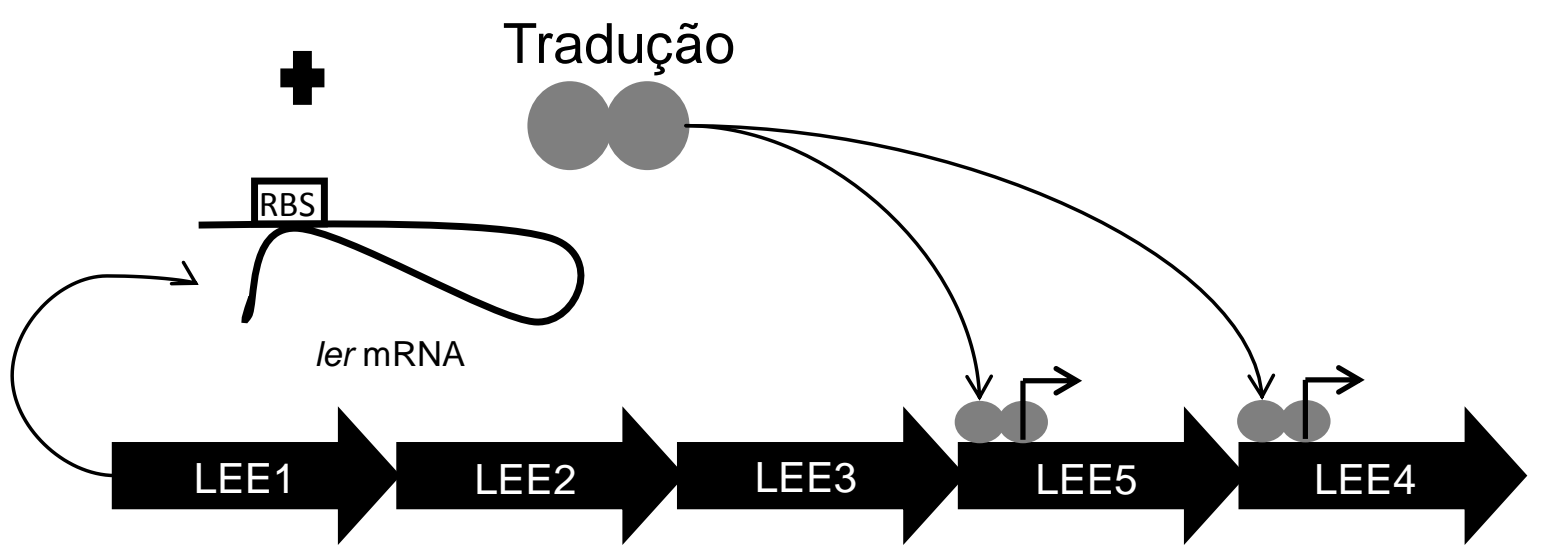

Figura 33 - Papel de Hfq na regulação dos fatores de virulência de Escherichia coli Enteropatogênica. 


\section{REFERÊNCIAS*}

AFSET, J. E.; BERGH, K.; BEVANGER, L. High prevalence of atypical enteropathogenic Escherichia coli (EPEC) in Norwegian children with diarrhea. J. Med. Microbiol., v. 52, p. 1015-1019, 2003.

AFSET, J.E.; BEVANGER, L.; ROMUNDSTAD, P.; BERGH, K. Association of atypical enteropathogenic Escherichia coli (EPEC) with prolonged diarrhoea. J. Med. Microbiol., v. 53, p. 1137-1144, 2004.

AFSET, J. E.; ANDERSSEN, E.; BRUANT, G.; HAREL, J.; WIELER, L.; BERGH, K. Phylogenetic background and virulence profile of atypical enteropathogenic Escherichia coli from a case control study using multilocus sequence typing and DNA microarray. J. Clin. Microbiol., v. 46, p. 2280-2290, 2008.

ARAUJO, J. M.; TABARELLI, G. F.; ARANDA, K. R.; FABBRICOTTI, S. H.; FAGUNDES-NETO, U.; MENDES, C. M.; SCALETSKY, I. C. Typical enteroaggregative and atypical enteropathogenic types of Escherichia coli are the most prevalent diarrhea-associated pathotypes among Brazilian children. J. Clin. Microbiol., v. 45, p. 3396-3999, 2007.

ARNOSTI, D. N. Regulation of Escherichia coli sigma F RNA polymerase by flhD and flhC flagellar regulatory genes. J. Bacteriol., v. 172, n. 7, p. 4106-4108, 1990.

BACA-DELANCEY, R. R.; SOUTH, M. M. T.; DING, X.; RATHER, P. N. Escherichia coli genes regulated by cell-to-cell signaling. Proc. Natl. Acad. Sci. USA, v. 96, p. 4610-4614, 1999.

BALDINI, M. M.; KAPER, J. B.; LEVINE, M. M.; CANDY, D. C.; MOON, H. W. Plasmid-mediated adhesion in enteropathogenic Escherichia coli. J. Pediatr. Gastroenterol. Nutr., v. 2, p. 534-539, 1983.

BARBA, J. et al. A Positive Regulatory Loop Controls Expression of the Locus of Enterocyte Effacement-Encoded Regulators Ler and GrIA. J. Bacteriol., v. 187, p. 7918-7930, 2005.

BARROS, S. F.; ABE, C. M.; ROCHA, S. P. D.; RUIZ, R. M.; BEUTIN, L.; TRABULSI, L. R.; ELIAS, W. P. Escherichia coli O125ac:H6 encompasses atypical enteropathogenic E. coli spp. that display the aggregative adherence pattern. J. Clin. Microbiol., v. 46, p. 4052-4055, 2008.

\footnotetext{
* De acordo com:

ASSOCIAÇÃO BRASILEIRA DE NORMAS TÉCNICAS. NBR 6023: informação e documentação: referências: elaboração. Rio de Janeiro, 2002.
} 
BHATT, S.; EDWARDS, A. N.; NGUYEN, H. T.; MERLIN, D.; ROMEO, T.; KALMAN, $D$. The RNA binding protein CsrA is a pleiotropic regulator of the locus of enterocyte effacement pathogenicity island of enteropathogenic Escherichia coli. Infect. Immun., v. 77, p. 3552-3568, 2009.

BERDICHEVSKY, T.; FRIEDBERG, D.; NADLER, C.; ROKNEY,A.; OPPENHEIM, A.; ROSENSHINE, I. Ler Is a Negative Autoregulator of the LEE1 Operon in Enteropathogenic Escherichia coli. J. Bacteriol., v. 187, p. 349-357, 2005.

BOJER, M. S. et al. Lack of the RNA chaperone Hfq attenuates pathogenicity of several Escherichia coli pathotypes towards Caenorhabditis elegans. Microbes and Infection / Institut Pasteur, v. 14, p. 1034-1039, 2012.

BUERIS, V.; SIRCILI, M. P.; TADDEI, C. R.; SANTOS, M. F.; FRANZOLIN, M. R.; MARTINEZ, M. B.; FERRER, S. R.; BARRETO, M. L.; TRABULSI, L. R. Detection of diarrheagenic Escherichia coli from children with and without diarrhea in Salvador, Bahia, Brazil. Mem. Inst. Oswaldo Cruz, v. 102, p. 836-844, 2007.

BUERIS, V. Interação de Escherichia coli Enteropatogenica (EPEC) atípica que apresenta o padrão de adesão localizado-like com a célula epitelial in vitro. 2008. Tese (Doutorado em Microbiologia) - Instituto de Ciências Biomédicas, Universidade de São Paulo, São Paulo, p. 131, 2008.

BUSTAMANTE, V. H. et al. PerC and GrlA independently regulate Ler expression in enteropathogenic Escherichia coli. Mol. Microbiol., v. 82, p. 398-415, 2011.

CHEN, H. D., FRANKEL, G. Enteropathogenic Escherichia coli: unraveling pathogenesis. FEMS Microbiol. Rev., v. 29, p. 83-98, 2005.

CHEN, Z. et al. Esre: a novel essential non-coding RNA in Escherichia coli. FEBS letters, v. 586, p. 1195-200, 2012.

CHEVANCE, F. F. V; HUGHES, K. T. Coordinating assembly of a bacterial macromolecular machine. Nat. Rev. Microbiol., v. 6, p. 455-465, 2008.

CHIANG, M.-K. et al. Impact of $\mathrm{Hfq}$ on global gene expression and virulence in Klebsiella pneumoniae. PloS One, v. 6, p. e22248, 2011.

CHILCOTT, G. S.; HUGHES, K. T. Coupling of flagellar gene expression to flagellar assembly in Salmonella enterica serovar typhimurium and Escherichia coli. Microbiology and molecular biology reviews : MMBR, v. 64, p. 694-708, 2000.

CLARKE, S. C. Diarrhoeagenic Escherichia coli - an emergin problem? Diagn. Infect. Dis., v. 41, p. 93-98, 2001.

CLARKE, M. B. et al. The QseC sensor kinase: a bacterial adrenergic receptor. Proc. Natl. Acad. Sci. USA, v. 103, p. 10420-10425, 2006.

COHEN, M. L. Changing patterns of infectious diseases. Nature, v. 406, p. 762-767, 2000. 
COHEN, M. B.; NATARO, J. P.; BERNSTEIN, D. I.; HAWKINS, J.; ROBERTS, N.; STAAT, M. A. Prevalence of diarrheagenic Escherichia coli in acute childhood enteritis: a prospective controlled study. J. Pediatr., v. 146, p. 54-61, 2005.

CRAVIOTO, A.; GROSS, R. J., SCOTLAND, S. M.; ROWE, B. An adhesive factor found in strains of Escherichia coli belonging to the traditional infantile enteropathogenic serotypes. Curr. Microbiol., v. 3, p. 95-99, 1979.

DATSENKO, K. A.; WANNER, B. L. One-step inactivation of chromossomal genes in Escherichia coli K-12 using PCR products. Proc. Natl. Acad. Sci. USA, v. 97, p. 6640-6645, 2000.

DE LAY, N.; GOTTESMAN, S. A complex network of small non-coding RNAs regulate motility in Escherichia coli. Mol. Microbiol., v. 86, p. 524-538, 2012.

DULGUER, M. V.; FABBRICOTTI, S. H.; BANDO S. Y.; MOREIRA-FILHO, C. A.; FAGUNDES-NETO, U.; SCALETSKY, I. C. A. Atypical enteropathogenic Escherichia coli strains: phenotypic and genetic profiling reveals a strong association between enteroaggregative $E$. coli heat-stable enterotoxin and diarrhea. J. Infect. Dis., v. 188, p. 1685-1694, 2003.

ERDEM, A. L. et al. Host protein binding and adhesive properties of $\mathrm{H} 6$ and $\mathrm{H} 7$ flagella of attaching and effacing Escherichia coli. J. Bacteriol., v. 189, p. 7426-35, 2007.

FANER, M. A; FEIG, A L. Identifying and characterizing Hfq-RNA interactions. Methods (San Diego, Calif.), v. 63, p. 144-159, 2013.

FRANZOLIN, M. R.; ALVES, R. C. B.; KELLER, R.; GOMES, T. A. T.; BEUTIN, L.; BARRETO, M. L.; MILROY, C. A.; STRINA, A.; RIBEIRO, H.; TRABULSI, L. R. Prevalence of diarrheagenic Escherichia coli in children with diarrhea in Salvador, Bahia, Brazil. Mem. Inst. Oswaldo Cruz, v. 100, p. 359-363, 2005.

FRANKEL, G.; PHILLIPS, A. D.; ROSENSHINE, I.; DOUGAN, G.; KAPER, J. B.; KNUTTON, S. Enteropathogenic and enterohaemorragic Escherichia coli: more subversives elements. Mol. Microbiol., v. 30, p. 911-921, 1998.

FRANZIN, F. M. Papel do sitema Al-3/Epinefrina na regulação da expressão gênica de Escherichia coli Enteropatogênica atípica. 2013. Tese (Doutorado) Instituto de Genética e Biologia Molecula, Universidade Estadual de Campinas, São Paulo, p. 111, 2013.

FRÖHLICH, K. S.; VOGEL, J. Activation of gene expression by small RNA. Curr. Opin. Microbiol., v. 12, p. 674-682, 2009.

GAUTHIER, A.; FINLAY,B. B. Type III secretion system inhibitors are potential antimicrobials. ASM News, v. 68, p. 383-387, 2002. 
GIRÓN, J. A.; HO, A. S.; SCHOOLNIK, G. K. An inducible bundle-forming pilus of enteropathogenic Escherichia coli. Science, v. 254, p. 710-713, 1991.

GIRÓN, J. A et al. The flagella of enteropathogenic Escherichia coli mediate adherence to epithelial cells. Mol. Microbiol., v. 44, p. 361-379, 2002.

GOLDBERG, M. D.; JOHNSON, M.; HINTON, J. C.; WILLIAMS, P. H. Role of the nucleoid-associated protein Fis in the regulation of virulence properties of enteropathogenic Escherichia coli. Mol. Microbiol., v. 41, p. 549-559, 2001.

GOMES, T. A. T.; IRINO, K.; GIRÃO, D. M.; GIRÃO, V. B.; GUTH, B. E.; VAZ, T. M.; MOREIRA, F. C.; CHINARELLI, S. H.; VIEIRA, M. A. M. Emerging enteropathogenic Escherichia coli strains? Emerg. Infect. Dis., v. 10, p. 1851-1855, 2004.

GOTTESMAN, S. The small RNA regulators of Escherichia coli: roles and mechanisms*. Annu. Rev. Microbiol., v. 58, p. 303-328, 2004.

GRANT, A. J.; FARRIS, M.; ALEFOUNDER, P.; WILLIAMS, P. H.; WOODWARD, M. J.; O'CONNOR, C. D. Co-ordination of pathogenicity island expression by the BipA GTPase in enteropathogenic Escherichia coli (EPEC). Mol. Microbiol., v. 48, p. 507521, 2003.

HAIKO, J.; WESTERLUND-WIKSTRÖM, B. The role of the bacterial flagellum in adhesion and virulence. Biology, v. 2, p. 1242-1267, 2013.

HANSEN, A.-M.; KAPER, J. B. Hfq affects the expression of the LEE pathogenicity island in enterohaemorrhagic Escherichia coli. Mol. Microbiol., v. 73, p. 446-465, 2009.

HENDERSON, C. A et al. Characterization of MicA interactions suggests a potential novel means of gene regulation by small non-coding RNAs. Nucl. Acids Res., v. 41, p. 3386-3397, 2013.

HUECK, C. J. Type III secretion systems in bacterial pathogens of animals and plants. Microbiol. Mol. Bio. Rev., v. 62, p. 379-433,1998.

HUSSEIN, R.; LIM, H. N. Disruption of small RNA signaling caused by competition for Hfq. Proc. Natl. Acad. Sci. USA, v. 108, p. 1110-1115, 2011.

IYODA, S. et al. The GrIR-GrlA regulatory system coordinately controls the expression of flagellar and LEE-encoded type III protein secretion systems in enterohemorrhagic Escherichia coli. J. Bacteriol., v. 188, p. 5682-5692, 2006.

KAPER, J. B. Defining enteropathogenic Escherichia coli. Rev. Microbiol., v. 27, p. 130-133, 1996.

KAPER, J. B.; NATARO, J. P.; MOBLEY, H. L. Pathogenic Escherichia coli. Nat. Rev. Microbiol., v. 2, p. 123-140, 2004. 
KENDALL, M. M. et al. Hfq virulence regulation in enterohemorrhagic Escherichia coli O157:H7 strain 86-24. J. Bacteriol., v. 193, p. 6843-6851, 2011.

KNUTTON, S.; BALDINI, M. M.; KAPER, J. B.; McNEISH, A. S. Role of plasmidencoded adherence factors in adhesion of enteropathogenic Escherichia coli to HEp2 cells. Infect. Immun., v. 55, p. 78-85, 1987.

KNUTTON, S.; DALDWIN, T.; WILLIAMS, P. H.; McNEISH, A. S. Actin accumulation at sites of bacterial adhesion to tissue culture cells: basis of a new dianostic test for enteropathogenic and enterohaemorragic Escherichia coli. Infect. Immun., v. 57, p. 1290-1298, 1989.

KULESUS, R. R. et al. Impact of the RNA chaperone Hfq on the fitness and virulence potential of uropathogenic Escherichia coli. Infec. Immun., v. 76, p. 3019-3026, 2008.

LA RAGIONE, R. M. et al. Recombinant anti-EspA antibodies block Escherichia coli O157:H7-induced attaching and effacing lesions in vitro. Microbes and Infection / Institut Pasteur, v. 8, p. 426-433, 2006.

LAY, N. DE; GOTTESMAN, S. A complex network of small non-coding RNAs regulate motility in Escherichia coli. Mol. Microbiol., v. 86, p. 524-538, 2012.

LENZ, D. H. et al. The small RNA chaperone Hfq and multiple small RNAs control quorum sensing in Vibrio harveyi and Vibrio cholerae. Cell, v. 118, n. 1, p. 69-82, 2004.

LENZ, D. H. et al. CsrA and three redundant small RNAs regulate quorum sensing in Vibrio cholerae. Mol. Microbiol., v. 58, p. 1186-1202, 2005.

LEVINE, M. M.; NATARO, J. P.; KARCH, H.; BALDINI, M. M.; KAPER, J. B.; BLACK, R. E.; CLEMENTS, M. L.; O'BRIEN, A. D. The diarrheal response of humans to some classic serotypes of enteropathogenic Escherichia coli is dependent on a plasmid encoding an enteroadhesiveness factor. J. Infect. Dis., v. 152, p. 550-559, 1985.

LIU, X.; MATSUMURA, P. The FIhD/FIhC complex, a transcriptional activator of the Escherichia coli flagellar class II operons. J. Bacteriol., v. 176, p. 7345-7351, 1994.

MAIRENA, E. C.; NEVES, B. C.; TRABULSI, L. R.; ELIAS, W. P. Detection of LEE 4 region-encoded genes from different enteropathogenic and enterohemorrhagic Escherichia coli serotypes. Curr. Microbiol., v. 48, p. 412-418, 2004.

McNAMARA, B. P.; KOUTSOURIS, A.; O'CONNELL, C. B.; NOUGAYREDE, J. P.; DONNENBERG, M. S.; HECHT, G. Translocated EspF protein from enteropathogenic Escherichia coli disrupts host intestinal barrier function. J. Clin. Invest., v. 107, p. 621-629, 2001.

MELLIES, J. L.; ELLIOT, S. J.; SPERANDIO, V.; DONNENBERG, M. S.; KAPER, J. $B$. The Per regulon of enteropathogenic Escherichia coli : identification of a 
regulatory cascade and a novel transcriptional activator, the locus of enterocyte effacement (LEE)-encoded regulator (Ler). Mol. Microbiol., v. 33, p. 296-306, 1999.

MIKA, F.; HENGGE, R. Small Regulatory RNAs in the Control of Motility and Biofilm Formation in E. coli and Salmonella. Int. J. Mol. Sci., v. 14, p. 4560-4579, 2013.

MIKA, F.; HENGGE, R. Small RNAs in the control of RpoS, CsgD, and biofilm architecture of Escherichia coli. RNA Biology, v. 11, p. 1-14, 2014.

MØLLER, T.; FRANCH, T.; HØJRUP, P.; KEENE, D. R.; BÄCHINGER, H. P.; BRENNAN, R. G.; VALENTIN-HANSEN, P. Hfq: A bacterial Sm-like protein that mediates RNA-RNA interaction. Mol. Cell, vol. 9, p. 23-30, 2002.

MOON, H. W.; WHIPP, S. C.; ARGENZIO, R. A.; LEVINE, M. M.; GIANNELLA, R. A. Attaching and effacing activities of rabbit and human enteropathogenic Escherichia coli in pig and rabbit intestines. Infect. Immun., v. 41, p. 1340-1351, 1983.

MORENO, A. C. R.; FERNANDES-FILHO, A.; GOMES, T. A. T.; RAMOS, S. T. S.; MONTEMOR, L. P. G.; TAVARES, V. C.; DOS SANTOS-FILHO, L. ; IRINO, K.; MARTINEZ, M. B. Etiology of childhood diarrhea in the northeast of Brazil: significant emergent diarrheal pathogens. Diagn. Microbiol. Infect. Dis., 2008.

NATARO, J. P.; KAPER, J. B.; ROBINS-BROWNE, R.; PRADO, V.; VIAL, P. A.; LEVINE, M. M. Patterns of adherence of diarrheagenic Escherichia coli to HEp-2 cells. Pediatr. Infect. Dis. J., v. 16, p. 829-831, 1987.

NATARO, J. P.; KAPER, J. B. Diarrheagenic Escherichia coli. Clin. Microbiol. Rev., v. 11, p. $142-201,1998$.

NGUYEN, R. N.; TAYLOR, L. S.; TAUSCHEK, M.; ROBINS-BROWNE, R. M. Atypical enteropathogenic Escherichia coli infection and prolonged diarrhea in children. Emerg. Infect. Dis., v. 12, p. 597-603, 2006.

NOVAK, E. A et al. Autoinducer-2 and QseC control biofilm formation and in vivo virulence of Aggregatibacter actinomycetemcomitans. Infect. Immun., v. 78, p. 2919-2926, 2010.

O'RYAN, M.; PRADO V.; PICKERING, L. K. A millennium update on pediatric diarrheal illness in the developing world. Semin. Pediatr. Infect. Dis., v. 16, p. 125136, 2005.

ORLANDI, P. P.; MAGALHÃES, G. F.; MATOS, N. B.; SILVA, T.; PENATTI, M.; NOGUEIRA, P. A.; SILVA, L. H. Etiology of diarrheal infections in children of Porto Velho (Rondonia, Western Amazon region, Brazil). Braz. J. Med. Biol. Res., v. 39, p. 507-517, 2006.

PADAVANNIL, A. et al. Structure of GrIR-GrlA complex that prevents GrlA activation of virulence genes. Nature Communications, v. 4, p. 2546, 2013. 
PAPENFORT, K.; VOGEL, J. Regulatory RNA in bacterial pathogens. Cell Host \& Microbe, v. 8, p. 116-127, 2010.

PARKER, C. T.; SPERANDIO, V. Cell-to-cell signalling during pathogenesis. Cell. Microbiol., v. 11, p. 363-369, 2009.

PELAYO, J. S.; SCALETSKY, I. C.; PEDROSO, M. Z.; SPERANDIO, V.; GIRÓN, J. A.; FRANKEL, G., TRABULSI, L. R. Virulence properties of atypical EPEC strains. J. Med. Microbiol., v. 48, p. 41-49, 1999.

ROBINS-BROWNE, R. M.; BORDUN, A. M.; TAUSCHEK, M.; BENNETT-WOOD, V. R.; RUSSELL, J.; OPPEDISANO, F.; LISTER, N. A.; BETTELHEIM, K. A.; FAIRLEY, C. K.; SINCLAIR, M. I.; HELLARD, M. E. Escherichia coli and community-acquired gastroenteritis, Melbourne, Australia. Emerg. Infect. Dis., v. 10, p. 1797-1805, 2004.

ROCHA, S. P. D. Analise estrutural e funcional da região LEE de Escherichia coli Enteropatogênica atípica. 2010. Tese (Doutorado em Biotecnologia) - Instituto de Ciências Biomédicas, Universidade de São Paulo, São Paulo, p. 141, 2010.

RODRIGUES, J.; SCALETSKY, I. C. A.; CAMPOS, L. C.; GOMES, T. A. T.; WHITTAM, T. S.; TRABULSI, L. R. Clonal structure and virulence factors in strains of Escherichia coli of the classic serogroup O55. Infect. Immun., v. 64, p. 2680-2686, 1996.

RODRIGUES, J.; ACOSTA, V. C.; CANDEIAS, J. M. G.; SOUZA, L. O.; FILHO, F. J. C. Prevalence of diarrheogenic Escherichia coli and rotavirus among children from Botucatu, São Paulo State, Brazil. Braz. J. Med. Biol. Res., v. 35, p. 1311-1318, 2002.

SAMBROOK, J.; FRITSCH, E. F.; MANIATIS, T. Molecular cloning: a laboratory manual. Cold Spring Harbor, NY: Cold Spring Harbor Laboratory Press, 1989.

SÁNCHEZ-SANMARTÍN, C.; BUSTAMANTE, V. H.; CALVA, E.; PUENTE, J. L. Transcriptional regulation of the orf19 gene and the tir-cesT-eae operon of enteropathogenic Escherichia coli. J. Bacteriol., v. 183, p. 2823-2833, 2001.

SALIM, N. N. et al. Requirement of upstream Hfq-binding (ARN)x elements in glmS and the Hfq C-terminal region for GlmS upregulation by sRNAs GImZ and GImY. Nucl. Acids Res., v. 40, p. 8021-8032, 2012.

SCALETSKY, I. C. A.; SILVA, M. L. M.; TRABULSI, L. R. Distinctive patterns of adherence of enteropathogenic Escherichia coli to HeLa cells. Infect. Immun., v. 45, p. 534-536, 1984.

SCALETSKY, I. C.; PEDROSO, M. Z.; OLIVA, C. A.; CARVALHO, R. L.; MORAIS, M. B.; FAGUNDES-NETO, U. A localized adherence-like pattern as a second pattern of adherence of classic enteropathogenic Escherichia coli to HEp-2 cells that is associated with infantile diarrhea. Infect. Immun., v. 67, p. 3410-3415, 1999. 
SCALETSKY, I. C.; FABBRICOTI, S. H.; SILVA, S. O.; MORAIS, M. B.; FAGUNDESNETO, U. HEp-adherent Escherichia coli strains associated with acute diarrhea, São Paulo, Brazil. Emerg. Infect. Dis., v. 8, p. 855-858, 2002.

SCHMIDT, M. A. LEEways: tales of EPEC, ATEC and EHEC. Cell. Microbiol., v. 12, p. 1544-1552, 2010.

SHAKHNOVICH, E. A; DAVIS, B. M.; WALDOR, M. K. Hfq negatively regulates type III secretion in EHEC and several other pathogens. Mol. Microbiol., v. 74, p. 347363, 2009.

SHAO, Y.; BASSLER, B. L. Quorum-sensing non-coding small RNAs use unique pairing regions to differentially control mRNA targets. Mol. Microbiol., v. 83, p. 599$611,2012$.

SIMONSEN, K. T. et al. A role for the RNA chaperone Hfq in controlling adherentinvasive Escherichia coli colonization and virulence. PloS one, v. 6, p. e16387, 2011.

SITTKA, A. et al. The RNA chaperone Hfq is essential for the virulence of Salmonella typhimurium. Mol. Microbiol., v. 63, p. 193-217, 2007.

SMITH, H.; SCOTLAND, S.; CHEASTY, T.; WILLSHAW, G.; ROWE, B. Enteropathogenic Escherichia coli infections in the United Kingdom. Rev. Microbiol., v. 27 , p. $45-49,1996$.

SOPER, T. J.; DOXZEN, K.; WOODSON, S. A. Major role for mRNA binding and restructuring in sRNA recruitment by Hfq. RNA (New York, N.Y.), v. 17, p. 15441550, 2011.

SPERANDIO, V.; TORRES, A. G.; KAPER, J. B. Quorum sensing Escherichia coli regulators $B$ and $C$ (QseBC): a novel two-component regulatory system involved in the regulation of flagella and motility by quorum sensing in E. coli. Mol. Microbiol., v. 43, p. 809-821, 2002.

SUDO, N. et al. A novel small regulatory RNA enhances cell motility in enterohemorrhagic Escherichia coli. J. Gen. Appl. Microbiol., v. 60, p. 44-50, 2014.

THOMASON, M. K. et al. A small RNA that regulates motility and biofilm formation in response to changes in nutrient availability in Escherichia coli. Mol. Microbiol., v. 84, p. 17-35, 2012.

TORRES, A. G.; KAPER, J. B. Multiple elements controlling adherence of enterohemorragic Escherichia coli O157:H7 to HelA cells. Infect. Immun., v. 71, p. 4985-4995, 2003.

TORRES, A. G.; ZHOU, X.; KAPER, J. B. Adherence of diarrheagenic Escherichia coli strains to epithelial cells. Infect. Immun., v. 73, p. 18-29, 2005. 
TRABULSI, L. R.; CAMPOS, L.; WHITTAM, T.; GOMES, T. A. T.; RODRIGUES, J.; GONÇALVES, A. Traditional and non-traditional enteropathogenic Escherichia coli serogroups. Rev. Microbiol., v. 27, p. 1-6, 1996.

TRABULSI, L. R.; KELLER, R.; GOMES, T.A.T. Typical and atypical enteropathogenic Escherichia coli. Emerg. Infect. Dis., v. 8, p. 508-513, 2002.

TU, K. C.; BASSLER, B. L. Multiple small RNAs act additively to integrate sensory information and control quorum sensing in Vibrio harveyi. Genes \& Develop., v. 21, p. 221-233, 2007.

do VALLE, G. R.; GOMES, T. A. T.; IRINO, K.; TRABULSI, L. R. The traditional enteropathogenic Escherichia coli (EPEC) serogroup 0125 comprises serotypes which are mainly associated with the category of enteroaggregative $E$. coli. FEMS Microbiol. Lett., v. 152, p. 95-100, 1997.

VECEREK, B. et al. Translational activation of rpoS mRNA by the non-coding RNA DsrA and Hfq does not require ribosome binding. Nucl. Acids Res., v. 38, p. 12841293, 2010.

VIEIRA, M. A. M.; ANDRADE, J. R. C.; TRABULSI, L. R.; ROSA, A. C. P.; DIAS, A. M. G.; RAMOS, S. R. T. S.; FRANKEL, G.; GOMES, T. A. T. Phenotypic and genotypic characteristics of Escherichia coli strains of non-enteropathogenic Escherichia coli (EPEC) serogroups that carry eae and lack the EPEC adherence factor and Shiga toxin DNA probe sequences. J. Infect. Dis., v. 183, p. 762-772, 2001.

VOGEL, J.; LUISI, B. F. Hfq and its constellation of RNA. Nat. Rev. Microbiol., v. 9, p. 578-589, 2011.

VOGT, S. L.; RAIVIO, T. L. Hfq reduces envelope stress by controlling expression of envelope-localized proteins and protein complexes in enteropathogenic Escherichia coli. Mol. Microbiol., v. 92, p. 681-697, 2014.

WAGNER, E. G. H. Cycling of RNAs on Hfq. RNA Biology, v. 10, p. 619-626, 2013.

WALTERS, M.; SPERANDIO, V. Autoinducer 3 and epinephrine signaling in the kinetics of locus of enterocyte effacement gene expression in enterohemorrhagic Escherichia coli. Infec. Immun., v. 74, p. 5445-5455, 2006.

WINARDHI, R. S.; GULVADY, R.; MELLIES, J. L.; YAN, J. Locus of Enterocyte Effacement-Encoded Regulator (Ler) of pathogenic Escherichia coli Competes Off Nucleoid Structuring Protein H-NS through Non-Cooperative DNA Binding. J. Biol. Chem., v. 289, p. 13739-13750, 2014.

WORLD HEALTH ORGANIZATION. Geneva, Switzerland, 1987.

YERUSHALMI, G. et al. Dynamics of Expression and Maturation of the Type III Secretion System of Enteropathogenic Escherichia coli. J. Bacteriol., v. 196, p. 2798-2806, 2014. 